\title{
ZUSGS
}

\section{Assessment of the Geoavailability of Trace Elements from Minerals in Mine Wastes: Analytical Techniques and Assessment of Selected Copper Minerals}

By Rhonda Driscoll, Phillip Hageman, William Benzel, Sharon Diehl, David Adams, Suzette Morman, and LaDonna Choate

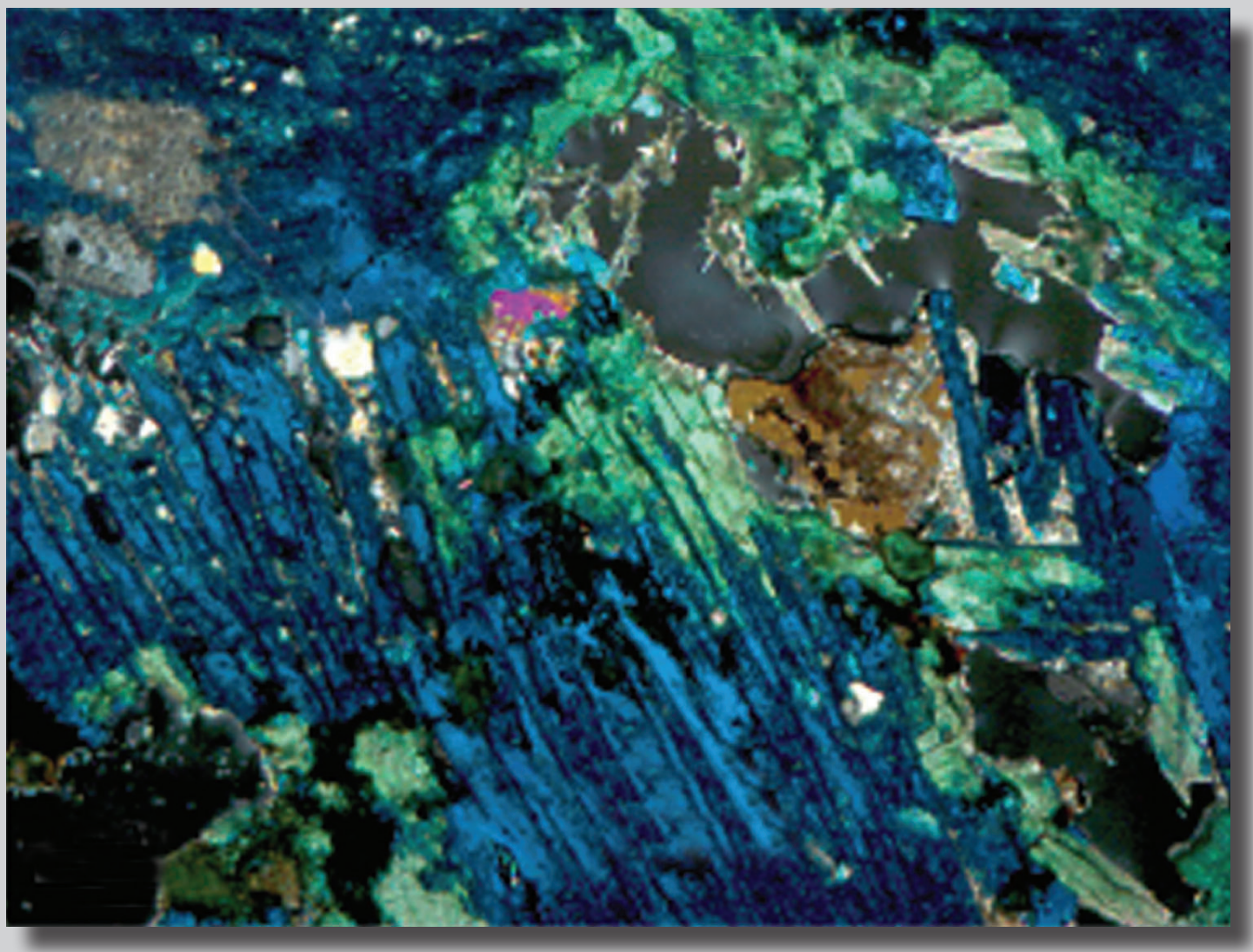

Scientific Investigations Report 2011-5211 


\title{
U.S. Department of the Interior \\ KEN SALAZAR, Secretary
}

\section{U.S. Geological Survey \\ Marcia K. McNutt, Director}

\section{U.S. Geological Survey, Reston, Virginia: 2011}

\author{
About USGS Products \\ For product and ordering information: \\ World Wide Web: http://www.usgs.gov/pubprod \\ Telephone: 1-888-ASK-USGS \\ For more information on the USGS - the Federal source for science about the Earth, its natural and \\ living resources, natural hazards, and the environment: \\ World Wide Web: http://www.usgs.gov \\ Telephone: 1-888-ASK-USGS
}

\section{About this Product}

Publishing support provided by

Denver Science Publishing Network

For more information concerning this publication, contact:

Center Director, USGS Central Mineral and Environmental Resources Science Center

Box 25046, Mail stop 973

Denver, C0 80225

(303) 236-1562

or visit the Central Mineral and Environmental Resources Science Center Web site at: http://minerals.cr.usgs.gov

\section{Suggested citation:}

Driscoll, Rhonda, Hageman, Phillip, Benzel, William, Diehl, Sharon, Adams, David, Morman, Suzette, and Choate, LaDonna, 2011, Assessment of the geoavailability of trace elements from minerals in mine wastes: analytical techniques and assessment of selected copper minerals: U.S. Geological Survey Scientific Investigations Report 2011-5211, pamphlet, 68 p.

Any use of trade, product, or firm names is for descriptive purposes only and does not imply endorsement by the U.S. Government.

Although this report is in the public domain, permission must be secured from the individual copyright owners to reproduce any copyrighted materials contained within this report. 


\section{Contents}

Abstract

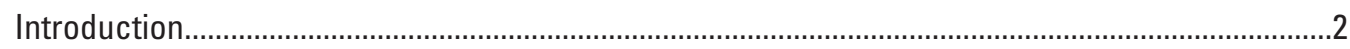

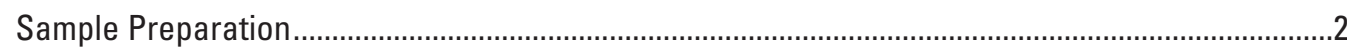

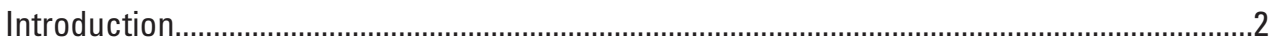

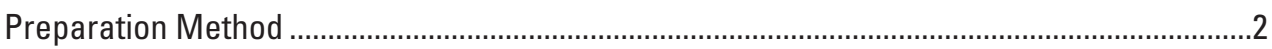

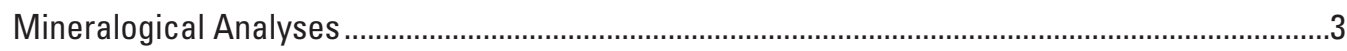

Introduction

Methods

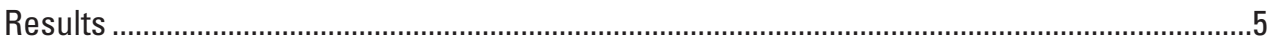

Carbonate Minerals Azurite and Malachite ………………………………………….......

Sulfide Minerals Chalcopyrite and Bornite .................................................................10

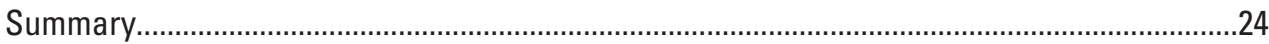

Bulk, Leachate, and Acid-Base Accounting Geochemical Study of Four Copper-Bearing

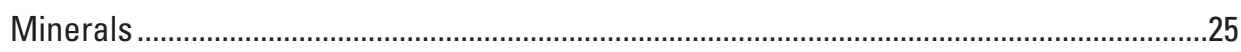

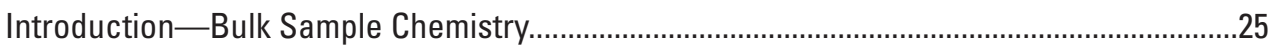

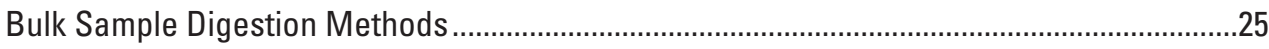

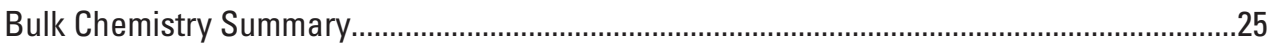

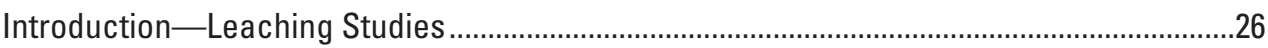

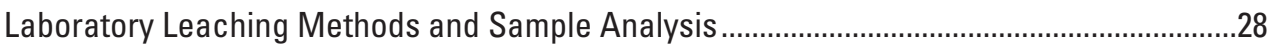

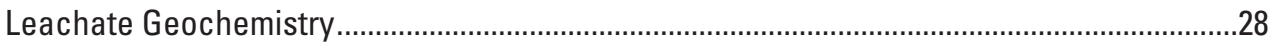

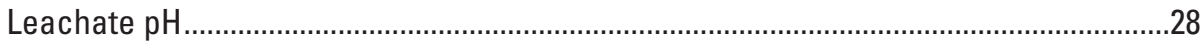

Leachate Specific Conductance (SC) …………………………………………......28

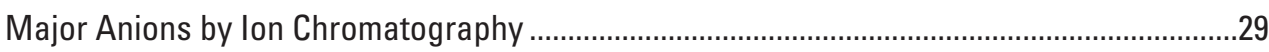

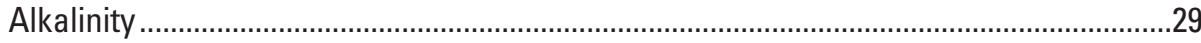

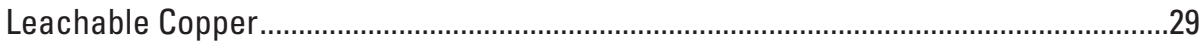

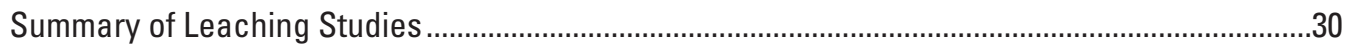

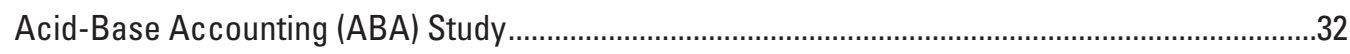

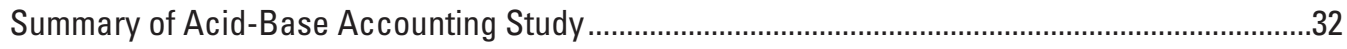

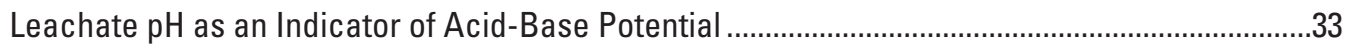

In Vitro Bioaccessibility Extractions ......................................................................................

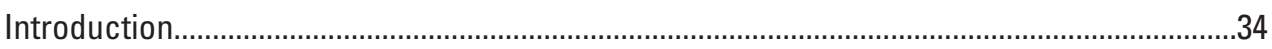

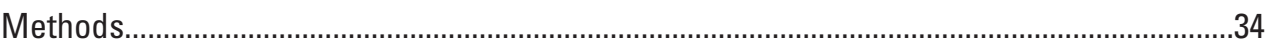

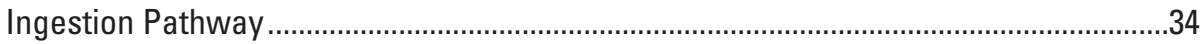

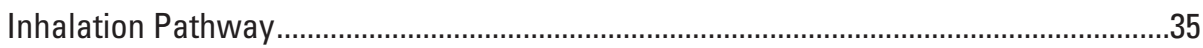

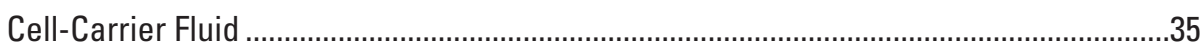

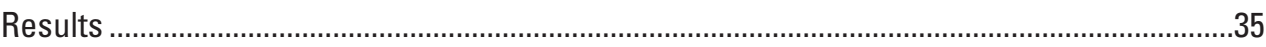

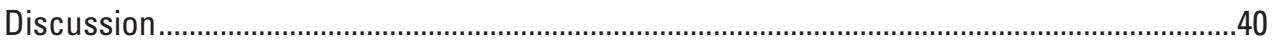

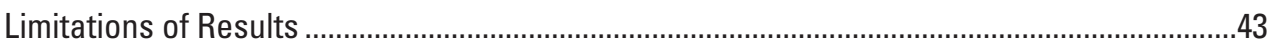

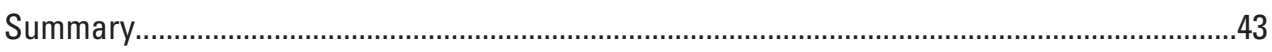

Procedure for Determination of Metal Toxicity Using MetPLATE ${ }^{\text {TM }}$.................................................44

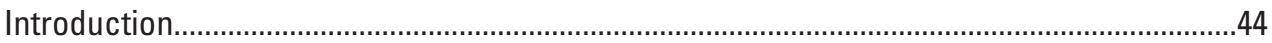

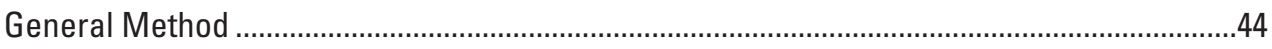

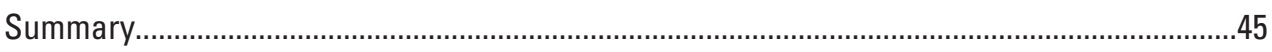

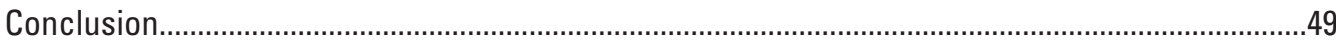

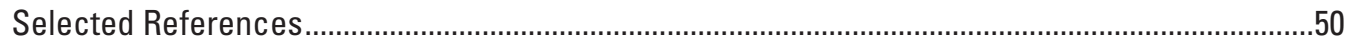




\section{Figures}

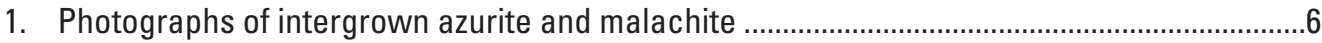

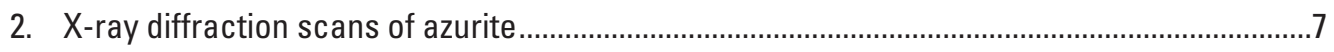

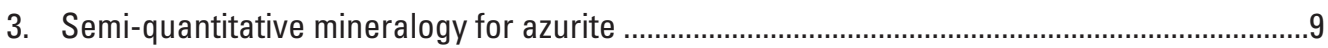

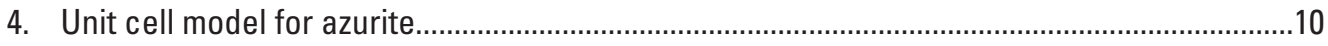

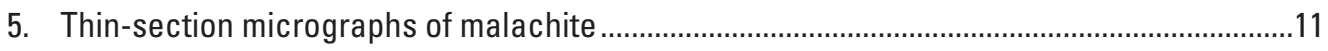

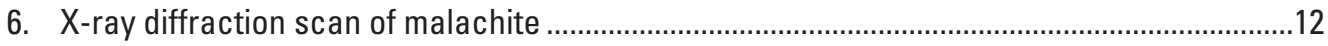

7. Semi-quantitative mineralogy for malachite …………......................................................13

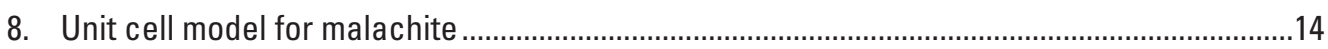

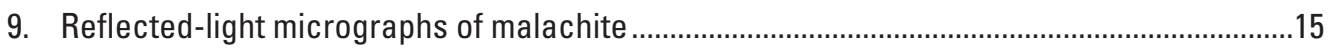

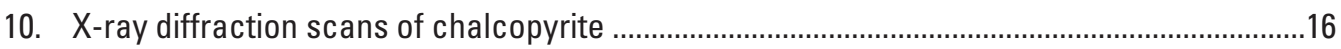

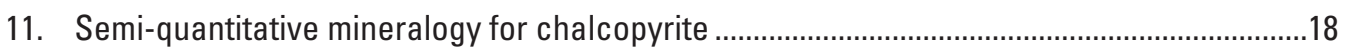

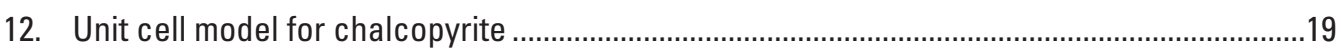

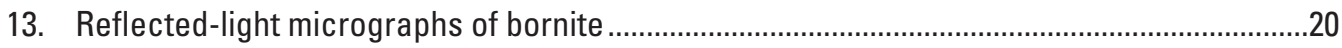

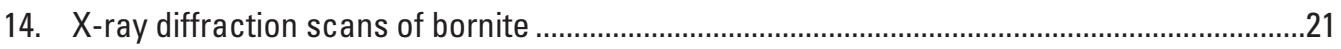

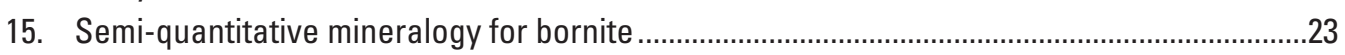

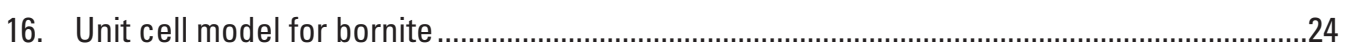

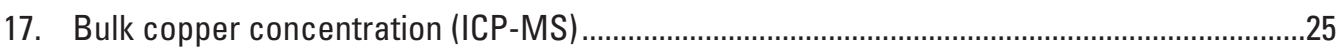

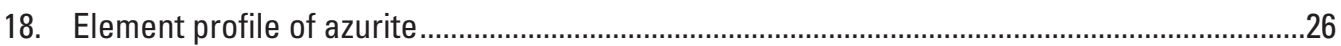

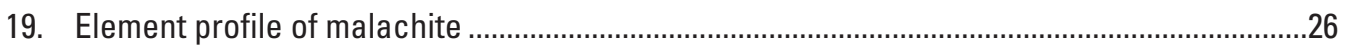

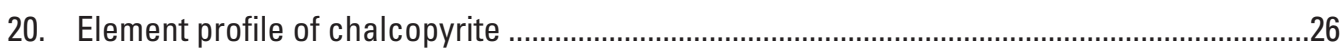

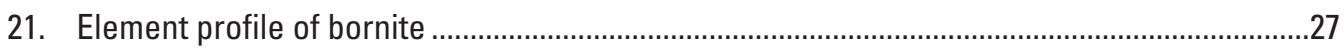

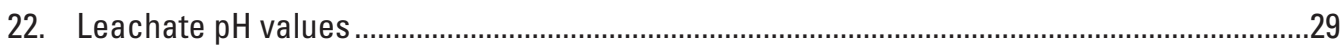

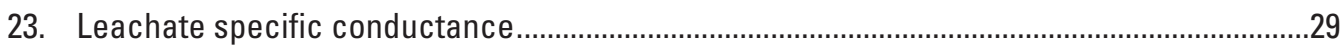

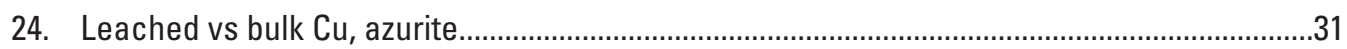

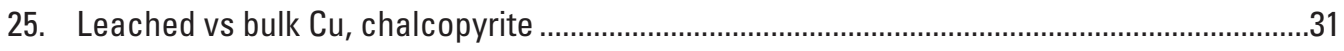

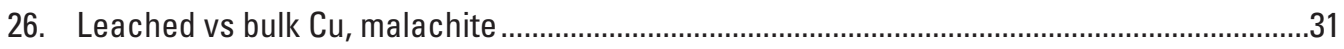

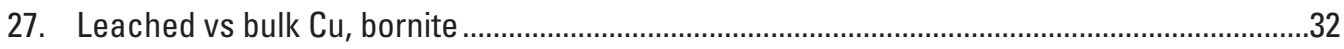

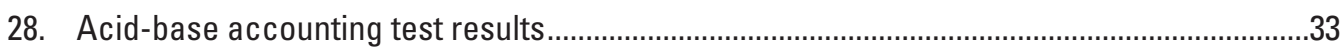

29. Water leachable $\mathrm{pH}$ and post-peroxide digestion $\mathrm{pH}$.......................................................33

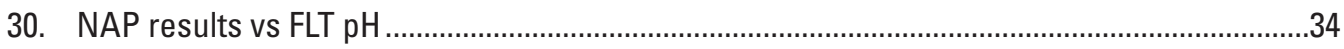

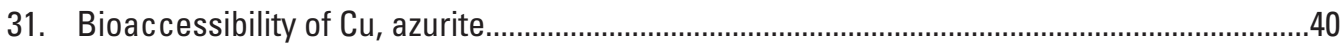

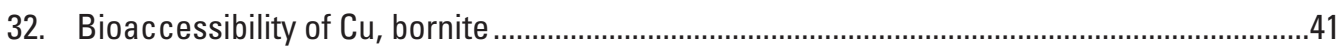

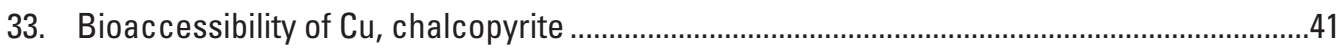

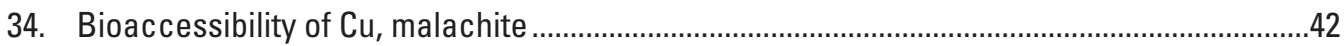

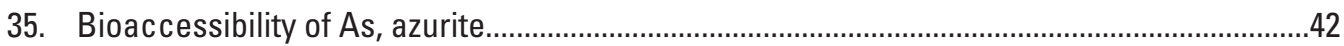

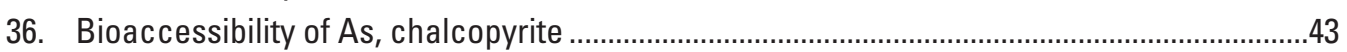

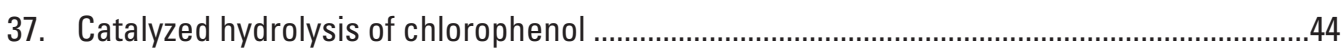

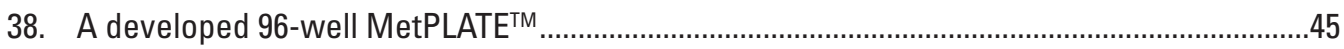

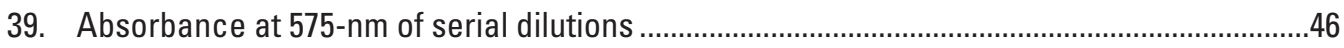

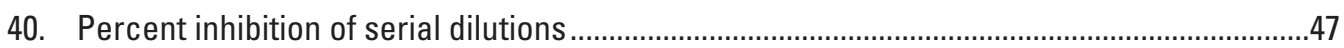

41. Percent inhibition showing linear regression .....................................................................48 


\section{Tables}

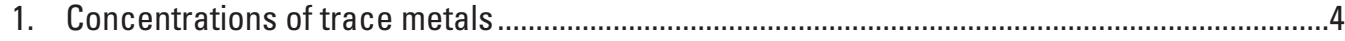

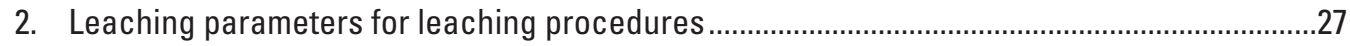

3. Leachate ion chromatography and alkalinity results ................................................................30

4. Total metal concentration and percent bioaccessibility for selected trace metals..................36

5. Summary of the $\mathrm{EC}_{50}$ values for four copper-bearing minerals .............................................47

\section{Appendices}

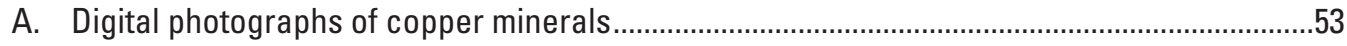

B. Scintag $\mathrm{x}$-ray diffractometer instrument set-up ..................................................................55

C. Bulk chemistry composition of four copper-bearing minerals ..................................................56

D. Leachate chemical composition of four copper mineral samples .............................................57

E. Leachate concentrations for measured elements by mineral...................................................61 


\title{
Assessment of the Geoavailability of Trace Elements from Minerals in Mine Wastes: Analytical Techniques and Assessment of Selected Copper Minerals
}

\author{
By Rhonda Driscoll, Phillip Hageman, William Benzel, Sharon Diehl, David Adams, Suzette Morman, \\ and LaDonna Choate
}

Abstract

In this study, we examined four randomly selected copper-bearing minerals - azurite, malachite, bornite, and chalcopyrite. Our objectives were to examine and enumerate the crystalline and chemical properties of each of the minerals; to determine which, if any, of the $\mathrm{Cu}$-bearing minerals might adversely affect systems biota; and to provide a multi-procedure reference. Our laboratory work included use of computational software for quantifying crystalline and amorphous material and optical and electron imaging instruments to model and project crystalline structures. We also conducted chemical weathering, human fluid, and enzyme simulation studies.

The analyses were conducted systematically: X-ray diffraction and microanalytical studies followed by a series of chemical, bio-leaching, and toxicity experiments.

$\mathrm{X}$-ray diffraction (XRD) analyses revealed that the selected mineral specimens contain zero to 15 percent accessory phases. Accessory minerals include sphalerite, andradite, phengite, and others. All crystalline phase and non-crystalline percentages, as well as unit cell dimensions, were determined using Reitveld-based quantitative software.

$\mathrm{X}$-ray diffraction analyses were supplemented by thinsection petrography, scanning electron microscopy (SEM), and electron microprobe analyses. Polished thin sections revealed accessory phases not detected by XRD: a silver sulfide inclusion, possibly acanthite, present in the azurite sample; probable cobaltite within the chalcopyrite specimen; and an unnamed bismuth sulfide included with bornite. Structure details such as microfracture networks, porosity, late stage growth zones, and residence sites of minor to trace elements were mapped by means of SEM.

A series of leachate studies was conducted using powdered splits of each mineral specimen. Leaching methods included the U.S. Geological Survey (USGS) Field Leach Test (Hageman, 2007a); U.S. Environmental Protection Agency (USEPA) Method 1312, versions pH 4.2 and pH 5.0 (USEPA, 1994); and USEPA Method 1311 (USEPA, 2004). Specific conductance, $\mathrm{pH}$, and major anion concentration data demonstrated that USEPA Method 1311 is unsuitable for a mineral/environmental characterization study. This method was developed by the Environmental Protection Agency (EPA) to simulate leaching conditions in mixed waste municipal landfills.

Inductively Coupled Plasma-Mass Spectrometry (ICPMS) analyses were conducted to determine bulk chemistry of the four minerals. In addition to copper $(\mathrm{Cu})$, iron, lead, and magnesium were reported as major elements of all four minerals. A comprehensive element profile was obtained for each study specimen.

A final geochemical experiment yielded real-time information about the acid generating-acid neutralizing potential of each of the study specimens. A split of each mineral was digested using the Lapakko and Lawrence (1993) method. All four copper-bearing minerals produced acid; chalcopyrite required the most added calcium carbonate $(\mathrm{CaCO} 3)$ for neutralization.

XRD, petrographic microanalysis, and experimental geochemical work provided insight into the composition and potential external environmental behavior of the four minerals. Separate bioaccessibility and metal toxicity studies examined the affect of the four copper-bearing minerals on certain human organs, and a specific bacteria colony.

The first of these component studies, an in vitro bioaccessibility test (IVBA), was designed to estimate the solubility and subsequent absorption potential of such earth materials as ground minerals, mineralized soils, and dusts. For this study, splits of the individual minerals were reduced to sizes generally thought to be ingestible and respirable. The reduced material was added to a simulated gastric fluid and subjected to a temperature and time-controlled agitation. An aliquot of the resultant solution was filtered and stabilized for gastric analysis. The remainder of the agitated solution was used for intestinal phase analyses following titration and the addition of porcine extract.

Modeling of in vivo solubility via the inhalation, or respirable, pathway required use of a lung simulant fluid (LSF) and a phagolysosomal simulant fluid (PSF). The work of Mattson (1994) and Stefaniak and others (2006) were adapted to our in vivo study. 
Upon completion of analyses one fact became clear: element solubility is determined by acidity. Copper and other elements are much more soluble in vitro than in vivo.

Finally, we examined the toxic, or inhibiting, effect of dissolved $\mathrm{Cu}$ on colonies of $E$. coli bacteria. In this experiment a $\mathrm{Cu}$ leachate was serially diluted. E. coli bacteria and a chromogenic substrate were introduced to the dilutions and incubated. After incubation, color changes in the substrate indicated levels of toxicity. Increasing toxicity, represented by a lighter color with low absorbance, increasingly inhibited production of the reproductive enzyme $\beta$-galactosidase present in E. coli.

\section{Introduction}

In 2008 the U.S. Geological Survey (USGS) launched a multi-year project designed to assess the characteristics of groups of common metal-bearing minerals typically associated with complex mine and industrial wastes. Minerals with a composition including one or more metals were obtained from research collections and commercial suppliers.

The behavior of metallic elements such as mercury $(\mathrm{Hg})$, zinc $(\mathrm{Zn})$, copper $(\mathrm{Cu})$, arsenic $(\mathrm{As})$, and lead $(\mathrm{Pb})$ have been the subject of numerous scientific papers and are at least partially understood with respect to their human health and environmental impact (USGS, 1995; Chowdhury and others, 2000; Alpers and others, 2005; Kim and others, 2009). Such research emphasizes the dispersion of metals in the environment. Our research differs in that it focuses on the fundamental properties of the source minerals from which metals are mobilized.

Fundamental properties include mineral composition, atomic-level structures, acid-producing potential, ingestion reactivity, and relative toxicity. To clarify or quantify these properties, straightforward analysis methods can be applied.

Consider the chalcopyrite (CuFeS2) specimen analyzed in this study: It hosts sphalerite and probable cobaltite as fracture fill; it produced a low leachate $\mathrm{pH}$; and, based on an acidbase accounting study, will generate acid sufficient to require considerable $\mathrm{CaCO} 3$ (calcium carbonate) for neutralization. Additional experimental data suggests that the element $\mathrm{Cu}$, predominant in chalcopyrite, is soluble in gastric fluids, and $\mathrm{Cu}$ toxicity, as determined by concentration, can interfere with the production of a key enzyme. We may reasonably conclude from these findings that this chalcopyrite specimen is unstable under certain weathering conditions. We may also reasonably conclude that the potentially toxic elements $\mathrm{Cu}, \mathrm{Co}$ (cobalt), $\mathrm{Fe}$ (iron), and $\mathrm{Zn}$ (zinc), detected in this sample, may be liberated from the chalcopyrite structure in response to weathering; exposure at some level to any one of these elements has the potential to compromise organ function. This knowledge could prove useful to regulators and land developers; it could form the basis of a containment or mediation plan prior to host-rock disturbance, or, if disturbance has already occurred, inform a capture or reclamation model. Information derived from a mineral assessment, whether that mineral is chalcopyrite $(\mathrm{Cu})$, galena $(\mathrm{Pb})$, or hydrozincite $(\mathrm{Zn})$, can and should influence mining and land development decisions.

Some methods for obtaining mineral information, as well as methods results are discussed in the following report.

\section{Sample Preparation}

\author{
Mineral digital photographs, Appendix A \\ Author: Rhonda Driscoll
}

\section{Introduction}

Nearly all experiments involving rock material require prepared samples of specific weight and size. For this study, mineral splits were prepared and distributed according to the specifications of various planned analyses.

Prior to analyses, it was assumed that each of the four selected specimens was a pure, single-phase mineral. This assumption was based on suppliers' descriptions and on a visual examination of each specimen: there were no visible transecting veinlets or inclusions, no secondary minerals growths, no evidence of pseudomorphism or replacement, and no obvious alteration, oxidation, or discoloration on any of the four specimens. Therefore, nothing was done to remove accessory phases.

The following section describes the methods used to reduce each mineral specimen to size fractions required for analyses.

\section{Preparation Method}

The chalcopyrite, bornite, malachite, and azurite samples were prepared for a battery of analyses:

- X-ray diffraction (XRD) analysis to identify and quantify mineral phases

- Thin section, polarized and reflected light microscopy, and scanning electron microscopy to identify minor to trace associated phases

- Electron microprobe analysis (EMPA) to investigate microscopic chemical variations

- Bulk chemical characterization including solid bulk chemistry, leachate chemistry using four leach tests, acid-base accounting, and total carbon (C) and sulfur (S)

- Bio-leaching experiments using simulated body fluids

- Leachate toxicity studies of individual metals and mixed metals 
Prior to sample preparation, the specimens were digitally photographed (see specimen photos, Appendix A, for general locality information). The photographs represent an archive of each mineral specimen and a record of its appearance and size prior to coarse crushing.

The weight of each specimen was in excess of 100 g. Analytical needs for each experimental method were as follows:

- A single billet measuring about one inch square by one-third of an inch thick was cut from each whole specimen using a water trim saw. Each billet was made into a single polished thin section for petrographic study.

The remainder of the specimen was crushed using a porcelain mortar and pestle. Porcelain is a fine-grained, nonporous ceramic consisting mostly of kaolin clay, quartz, and feldspar. It has a hardness of about seven on the Mohs scale ${ }^{1}$. The Cu-bearing minerals examined in this study range in hardness from 3 (bornite) to 4 (chalcopyrite). Use of the porcelain mortar and pestle prevented over-grinding and introduced far less contaminant than conventional metal grinding disks or impact balls.

- A $3 \mathrm{~g}$ split of each mineral specimen was reserved for XRD analysis (X-ray diffractometry) to accurately determine specimen purity. These splits were reduced from about $0.75 \mathrm{~mm}$ (200 mesh or 0.0029 in.) to a flour-like consistency using an agate mortar and pestle.

- $75 \mathrm{~g}$ of each mineral, ranging in size from $<2 \mathrm{~mm}$ to $>0.75 \mathrm{~mm}$, was prepared for leaching experiments. After water-leach experiments were completed, excess leachate was provided for toxicity studies.

- $\quad 0.4 \mathrm{~g}$ of $<0.75 \mathrm{~mm}$ material was prepared for inductively coupled plasma-mass spectrometry (ICP-MS) and total sulfur and carbonate-carbon analyses.

- $\quad 4.5 \mathrm{~g}$ of $<0.75 \mathrm{~mm}$ material was reserved for acidbase accounting experiments.

- $\quad 5.0 \mathrm{~g}$ of $<2 \mathrm{~mm}$ was provided for bioaccessibility extractions.

\footnotetext{
${ }^{1}$ A scale for classifying minerals based on relative hardness, determined by the ability of harder minerals to scratch softer ones. The scale includes the following minerals, in order from softest to hardest: 1. talc; 2. gypsum; 3. calcite; 4. fluorite; 5 . apatite; 6. orthoclase; 7. quartz; 8. topaz; 9. corundum; 10. diamond.
}

\section{Mineralogical Analyses}

\author{
X-ray Powder Diffraction and Microanalytical Studies: Thin- \\ Section, SEM, and EMPA micrographs
}

X-ray Diffraction instrument set-up and specifics, Appendix B

Authors: William M. Benzel, Sharon F. Diehl, and David T. Adams

\section{Introduction}

In addition to leachate studies (see Hageman, this volume), the selected $\mathrm{Cu}$-bearing minerals were examined by $\mathrm{X}$-ray powder diffraction, petrographic and scanning electron microscope, and electron microprobe to (1) identify basic mineralogy and associated structural and textural features, (2) calculate the unit cell of the $\mathrm{Cu}$ mineral and estimate the amorphous content of the mineral sample, (3) quantify trace element content associated with the main mineral phase, and (4) determine the residence, or mode of occurrence, of trace elements, such as whether trace metals are homogeneously distributed within the mineral or associated with mineral inclusions. By utilizing microanalytical techniques, the mode of occurrence of major, minor, and trace elements can be determined, but only at the detection limits of each of the instruments. The microanalytical study complements the XRD data by validating major mineralogy results, as well as showing the presence of accessory minerals that are below XRD detection limits. Leachate studies are also supported by showing the exact mineralogic residence sites of minor to trace elements that were detected in leachate solutions.

\section{Methods}

Polished standard thin sections of four mineral samplesazurite $\left(\mathrm{Cu}_{3}\left[\mathrm{OH} \mid \mathrm{CO}_{3}\right]_{2}\right)$, chalcopyrite $\left(\mathrm{CuFeS}_{2}\right)$, bornite $\left(\mathrm{Cu}_{5} \mathrm{FeS}_{4}\right)$, and malachite $\left(\mathrm{Cu}_{2}\left[\left(\mathrm{OH}_{2}\right)_{2} \mid \mathrm{CO}_{3}\right]\right)$-were examined in reflected-light microscopy and with a JEOL 5800LV scanning electron microscope (SEM), equipped with a Thermo NORAN silicon drift energy-dispersive spectroscopy detector (EDS) to determine basic mineralogy, identify textures or any structural defects, and for qualitative and semiquantitative analysis of trace- and minor-element content and their distribution in the minerals. The SEM has an element detection limit of approximately 500-1,000 parts per million (ppm).

Concentrations of trace metals in the main mineral phases were determined with a JEOL JXA-8900 electron microprobe analyzer (EMPA) (table 1).

There has been an increasing awareness that element associations and residence sites of trace metals in minerals are important in determining weathering behavior, not just the concentration of a trace element within a mineral (Diehl and others, 2006, 2007); therefore, a digital element map showing 
Table 1. Concentrations of trace metals in four Cu-bearing minerals using an electron microprobe instrument. Major- and trace-element content of Cu-bearing minerals were averaged.

[n, number of spot analyses; wt $\%$, weight percent]

\begin{tabular}{|c|c|c|c|c|c|c|c|c|c|c|c|c|c|c|c|}
\hline $\begin{array}{l}\text { Mineral } \\
\text { location }\end{array}$ & $\mathbf{n}$ & $\begin{array}{c}\text { Ag } \\
\mathbf{w t} \%\end{array}$ & $\begin{array}{c}\mathrm{C} \\
\mathrm{wt} \% \\
\end{array}$ & $\begin{array}{c}\text { Cd } \\
\mathbf{w t} \%\end{array}$ & $\begin{array}{c}\mathrm{Co} \\
\mathrm{wt} \%\end{array}$ & $\begin{array}{c}\mathrm{Cu} \\
\mathbf{w t} \%\end{array}$ & $\begin{array}{c}\text { Fe } \\
\mathbf{w t} \%\end{array}$ & $\begin{array}{c}\mathbf{H} \\
\mathbf{w t} \%\end{array}$ & $\begin{array}{r}\text { Mg } \\
\mathbf{w t} \%\end{array}$ & $\begin{array}{c}\mathrm{O} \\
\mathbf{w t} \%\end{array}$ & $\begin{array}{c}\mathrm{Ni} \\
\mathrm{wt} \%\end{array}$ & $\begin{array}{c}\mathrm{S} \\
\mathrm{wt} \%\end{array}$ & $\begin{array}{c}\mathrm{Sr} \\
\mathrm{wt} \%\end{array}$ & $\begin{array}{c}\mathrm{Zn} \\
\mathbf{w t} \%\end{array}$ & Total \\
\hline $\begin{array}{c}\text { Azurite } \\
\text { Anhui Province, China }\end{array}$ & 99 & 0.002 & 6.97 & NA & 0.00 & 52.99 & 0.01 & 0.91 & NA & 39.15 & 0.00 & NA & NA & 0.03 & 100.07 \\
\hline Ideal stoichiometry & & & 6.97 & & & 55.31 & & 0.58 & & 37.14 & & & & & \\
\hline $\begin{array}{c}\text { Malachite } \\
\text { Shaba Province, Zaire }\end{array}$ & 72 & 0.002 & 5.43 & NA & 0.03 & 55.88 & 0.00 & 1.09 & NA & 37.27 & 0.33 & NA & NA & 0.04 & 100.04 \\
\hline Ideal stoichiometry & & & 5.43 & & & 57.48 & & 0.91 & & 36.18 & & & & & \\
\hline $\begin{array}{c}\text { Bornite } \\
\text { Superior, Arizona }\end{array}$ & 10 & 2.17 & NA & 0.01 & 0.01 & 60.51 & 11.08 & NA & 0.04 & NA & 0.00 & 25.62 & 0.02 & 0.00 & 99.47 \\
\hline Ideal stoichiometry & & & & & & 63.31 & 11.13 & & & & & 25.56 & & & \\
\hline $\begin{array}{c}\text { Chalcopyrite } \\
\text { Butte, Montana }\end{array}$ & 10 & 0.03 & NA & 0.00 & 0.04 & 33.80 & 30.14 & NA & 0.02 & NA & 0.00 & 34.92 & 0.02 & 0.00 & 98.98 \\
\hline Ideal stoichiometry & & & & & & 34.63 & 30.43 & & & & & 34.94 & & & \\
\hline
\end{tabular}


the spatial distribution of nickel in the malachite sample was generated on the electron probe to demonstrate the common inhomogeneous distribution of trace metals in ore minerals. Powder X-ray diffraction analysis (XRD) was employed to make two measurements on each specimen. First, the XRD scan was interpreted to identify mineral phases present in the sample. The second measurement determined the unit cell parameters of the copper-bearing mineral. The unit cell of each specimen is compared to the calculated unit cell of an idealized pure end-member mineral (a chemically pure mineral with no substitutions). The difference between the calculated and actual mineral unit cells reflects chemical substitutions and strains and stresses in the crystal structure. These factors influence the stability, reactivity, and solubility of the mineral.

A less than $0.75 \mathrm{~mm}$-sized separate of each mineral was provided for analysis. This material was further reduced in size to approximately $50 \mu \mathrm{m}$ (micrometer) using an agate mortar and pestle. Two grams (if available) of each hand-ground powder was mixed with $20 \mathrm{~mL}$ of propanol (propyl alcohol) and micronized in a McCrone mill for 4 minutes. The milled particles were less than $5 \mu \mathrm{m}$ in size. After drying in air, the micronized powder was disaggregated by lightly grinding in a mortar and pestle. Next, an appropriate amount of corundum (Linde C micronized alumina) was added to the sample to yield a mixture with 10 percent by weight corundum as an internal standard. The mixture was transferred to a plastic vial containing two polystyrene balls; the vial was shaken for 10 minutes in a Spex Mixer mill. The blended powder was then sieved through a $250 \mu \mathrm{m}$ screen yielding a fluffy powder made up of aggregates of the fine particles. To minimize preferred orientation, the sieved material was side packed into a Scintag XRD instrument sample holder.

Accessory minerals were identified in three of the four specimens. Two of the four samples were provided in limited supply. These were processed following the same procedure, but they were top loaded onto a zero background quartz plate inserted into the Scintag instrument sample holder to reduce the amount of sample necessary to fill the well.

X-ray diffraction scans were collected on a Scintag X-1 diffractometer with Bragg Brentano geometry, theta-theta motion with a Scintag Peltier cooled energy dispersive detector set to collect only $\mathrm{K} \alpha$ radiation. The instrument set-up parameters and calibration are described in Appendix B.

\section{Results}

\section{Carbonate Minerals Azurite and Malachite}

The two carbonate specimens, azurite and malachite, are closely related to each other but have very different stability fields in the natural environment. Azurite does not form a solid solution series with any other metal carbonate hydroxide. The most common alteration arises from weathering, where some of the carbon dioxide $(\mathrm{CO} 2)$ units are replaced by water $(\mathrm{H} 2 \mathrm{O})$ following the chemical reaction:

$$
\begin{aligned}
2 \mathrm{Cu}_{3}\left(\mathrm{CO}_{3}\right)_{2}(\mathrm{OH})_{2}+\mathrm{H} 2 \mathrm{O} & \rightarrow 3 \mathrm{Cu}_{2}\left(\mathrm{CO}_{3}\right)(\mathrm{OH})_{2}+\mathrm{CO}_{2} \\
\text { Azurite } & \rightarrow \text { malachite }
\end{aligned}
$$

in which azurite is converted to malachite. During this weathering process, azurite and malachite form intergrowths. (fig. 1A).

\section{Azurite}

Figure $2 A$ is the XRD scan of the azurite specimen; fig. $2 B$ shows the same scan with the intensity scale expanded to reveal trace minerals. The result of the whole pattern fit (WPF) semi-quantitative analysis (fig. 3) indicates the specimen consists of azurite (53 percent) with malachite (10 percent), quartz (25 percent), mica (9 percent), barite ( 2 percent), and hematite ( 1 percent). In addition, approximately 4 percent of the specimen is amorphous material. The unit cell dimensions of the azurite (fig. 4) is comparable to the ideal unit cell dimensions for an end-member azurite phase (unit cell models from Jade Software). The ranges of cell dimensions reported in the literature for natural azurite are shown and the unit cell for this azurite specimen falls well within the reported range.

Leachate studies of azurite show high concentrations of potassium, magnesium, aluminum, iron, and minor concentrations of other metals such as silver, nickel, lead, and zinc. In thin section under transmitted light, tabular crystals of blue azurite show partial alteration to a green copper carbonate mineral, probably malachite, especially around voids, which are open to the infiltration of precipitation and oxygen (fig. $1 A$ ). As discussed above, malachite is a more stable oxidized copper carbonate and is a common alteration product of azurite.

Micron to submicron-sized silver-sulfide mineral inclusions were detected in backscatter SEM, but not by XRD (fig. $1 C$ ). Mineral inclusions of silver sulfide are roughly submicron to 6 micrometers in size. Although the silver-sulfide minerals are not a major component of the azurite sample, trace amounts of silver were detected in the bulk chemistry analyses (Appendix C); the silver-sulfide mineral inclusions may be reactive because of the large surface area of the micron-sized grains.

The high potassium- and aluminum-bearing leachates (See Hageman, this volume) suggest the presence of clays; in transmitted light, fine-grained sericite (identified as mica by XRD) is interstitial to laths of azurite crystals (fig. 1B). Quartz grains are abundant and commonly associated with the sericite. Barite, largely detected within voids, was common. Other identified accessory minerals were cerium-lanthanum monazite, gypsum, and titanium oxide, most likely rutile.

A SEM backscatter micrograph shows the distribution of alteration phases around voids and silver-sulfide mineral inclusions in the azurite specimen (fig. $1 C$ ). In addition to alteration to malachite, copper sulfates were detected around minor void areas. Alteration phases are highly irregular in shape and range in size from 2 to $25 \mu$. 

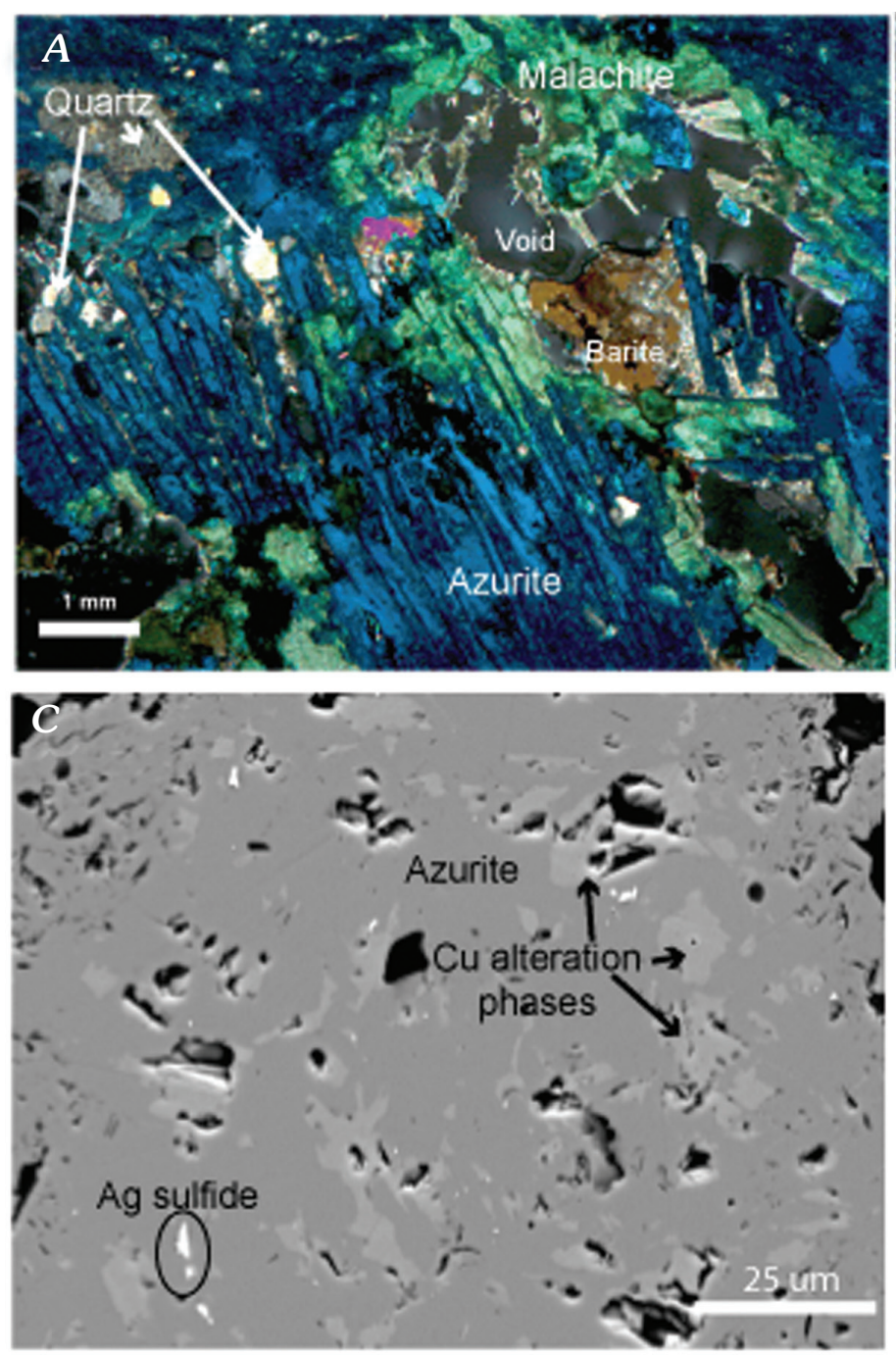

\section{Malachite}

The malachite sample is composed of green equant crystals of copper carbonate (fig. 5A). As in azurite, the strong coloration is due to copper, but malachite is the more oxidized mineral.

XRD analysis of this specimen (fig. 6) revealed the malachite to be pure on a bulk scale; there were no accessory phases above the detection limits of the method.

The specimen is estimated to have 4 percent amorphous content (fig. 7), most likely related to unidentified clay-like material in void spaces.

The calculated unit cell dimensions (fig. 8) suggest the "a" and "b" dimensions are shortened compared to literature values. Malachite does form a solid solution series with three end-member minerals: glaukosphaerite $(\mathrm{Cu}, \mathrm{Ni})_{2}\left(\mathrm{CO}_{3}\right)$ $(\mathrm{OH})_{2}$, kolwezite $(\mathrm{Cu}, \mathrm{Co})_{2}\left(\mathrm{CO}_{3}\right)(\mathrm{OH})_{2}$, and mcguinessite $(\mathrm{Cu}, \mathrm{Mg})_{2}\left(\mathrm{CO}_{3}\right)(\mathrm{OH})_{2}$. The unit cell dimensions for these three minerals are also listed in the figure, which show the unit cell can shrink and expand to accommodate numerous metal substitutions for copper. The $\mathrm{b}$ axis dimension of the malachite is $11.935 \AA$, similar to the $b$-axis dimension of glaukosphaerite

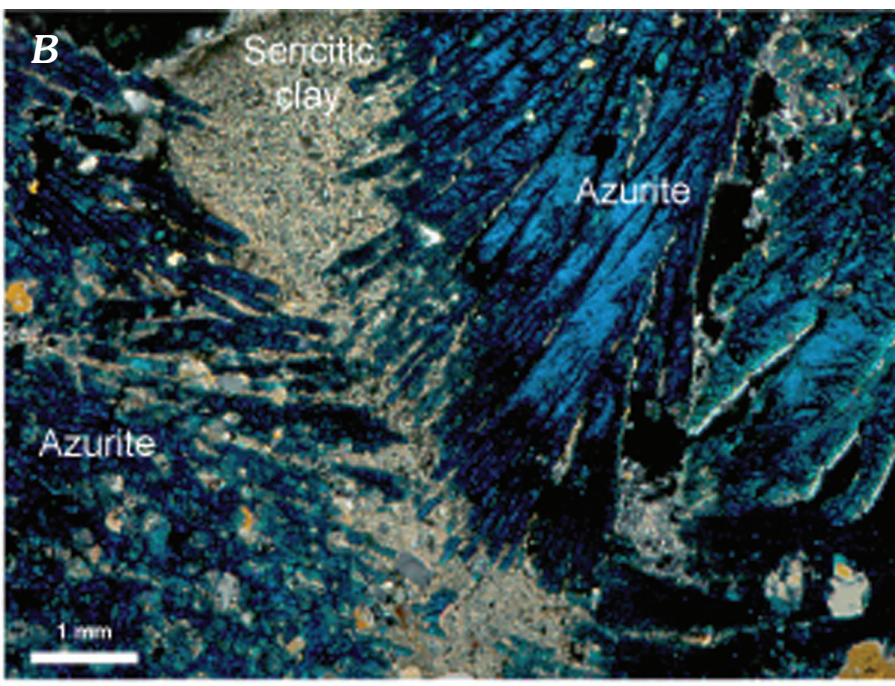

Figure 1 A-C. A. Azurite-Malachite Intergrowths. Transmitted light micrograph, showing tabular crystals of azurite partially altered to green malachite around void areas. Quartz grains are common. Barite was observed as a partial void-filling mineral. B. Backscatter micrograph showing two copper phases, medium gray = azurite; light gray = alteration copper mineral. Bright white areas are silver-sulfide mineral inclusions (black oval). Irregular black areas are voids. $C$. Transmitted light micrograph shows sericitic clay mica interstitial to tabular crystals of azurite. Quartz grains (pale gray) are distributed throughout the thin section.

which has nickel substituting for copper in the lattice. The a/c axial ratio for the malachite in this study is 2.923 which, when compared to the axial ratio of an ideal malachite (2.953) and glaukosphaerite (3.042), suggests that the amount of nickel substitution is limited to approximately $1 / 8$ th of the available metal atom sites.

Mineral inclusions were not apparent in the malachite thin section (figs. $5 A, 5 B$ ), but metals such as nickel and cobalt were detected in both microprobe analyses and leachate solutions (table 1 and Hageman, this volume). Common impurities reported in malachite are zinc, cobalt, and nickel. A backscatter SEM image of the malachite does not reveal mineral inclusions (fig. 5B), but an EMPA element-intensity map of nickel of the same area shows the inhomogeneous distribution of nickel; the cobalt element- intensity map also tracked with nickel distribution (fig. 5C). Nickel and cobalt were locally enriched in late-stage growth zones, especially at the edges of rhombs, indicating that these metals were incorporated within the lattice structure. Because of the inhomogeneous distribution of metals in the malachite sample, spot analyses were gathered in nickel-rich and nickel-poor areas and averaged (table 1). The malachite sample is porous; 


\section{Azurite with corundum internal standard}

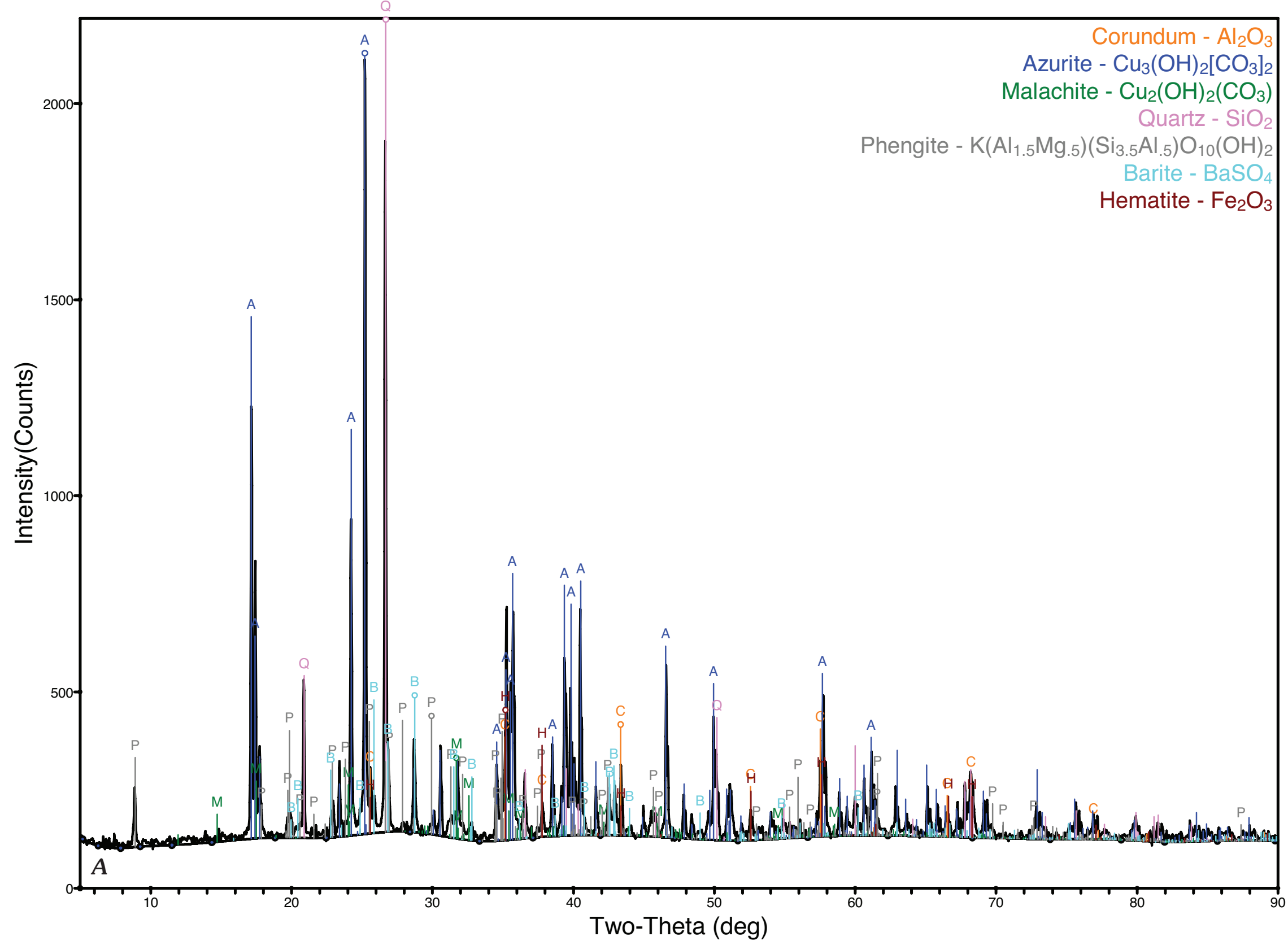

Figure $2 A$ and $2 B$ (above and next page). XRD scan of Azurite Specimen. At top, full scale scan of azurite specimen showing accessory minerals; at bottom, intensity scale is expanded to show trace mineral phases including barite, hematite and sericite (mica). 


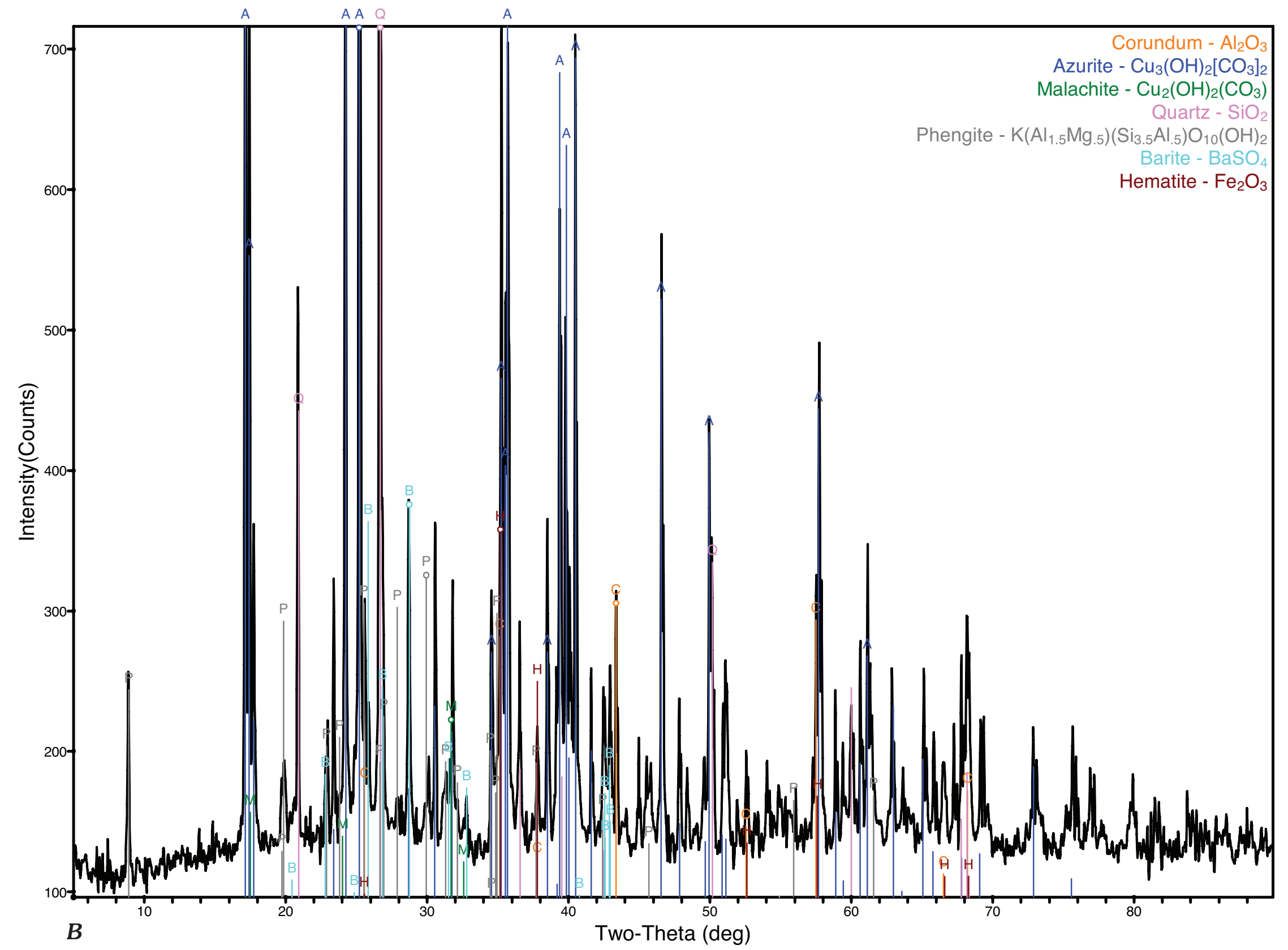

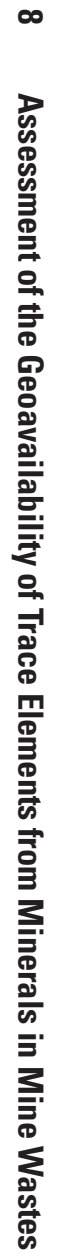




\section{Azurite with corundum internal standard}

Phase ID

Azurite - $\mathrm{Cu}_{3}(\mathrm{OH})_{2}\left(\mathrm{CO}_{3}\right)_{2}$
Space Group

$\mathrm{P} 2{ }_{1} / \mathrm{c}(14)$ a

5.00937 b

5.84627 c

10.34531
Alpha 90.000
Beta Gamma

$92.447 \quad 90.000$

\section{Phase ID (7)}

Azurite $-\mathrm{Cu}_{3}(\mathrm{OH})_{2}\left(\mathrm{CO}_{3}\right)_{2}$

$\square$ Quartz low - $\mathrm{SiO}_{2}$

Malachite - $\mathrm{Cu}_{2}(\mathrm{OH})_{2}\left(\mathrm{CO}_{3}\right)$

Phengite $2 \mathrm{M} 1-\mathrm{K}\left(\mathrm{Al}_{1.5} \mathrm{Mg}_{.5}\right)\left(\mathrm{Si}_{3.5} \mathrm{Al}_{.5}\right) \mathrm{O}_{10}(\mathrm{OH})_{2}$

Barite - $\mathrm{BaSO}_{4}$

Hematite - $\mathrm{Fe}_{2} \mathrm{O}_{3}$

Corundum $-\mathrm{Al}_{2} \mathrm{O}_{3}$

Wt\%
53
25
10
9
2
1

Wt\%

25

10

9

2

1

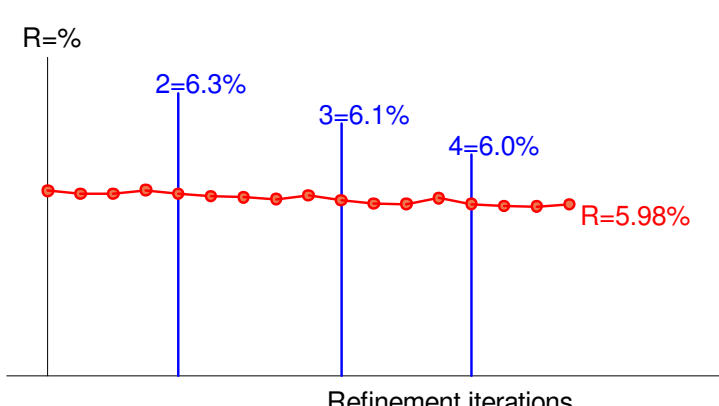

Refinement iterations

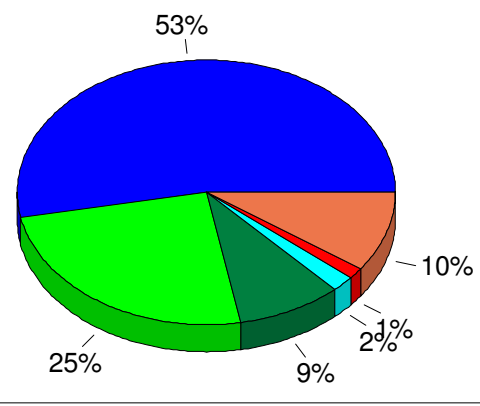

$\mathrm{Wt} \%$

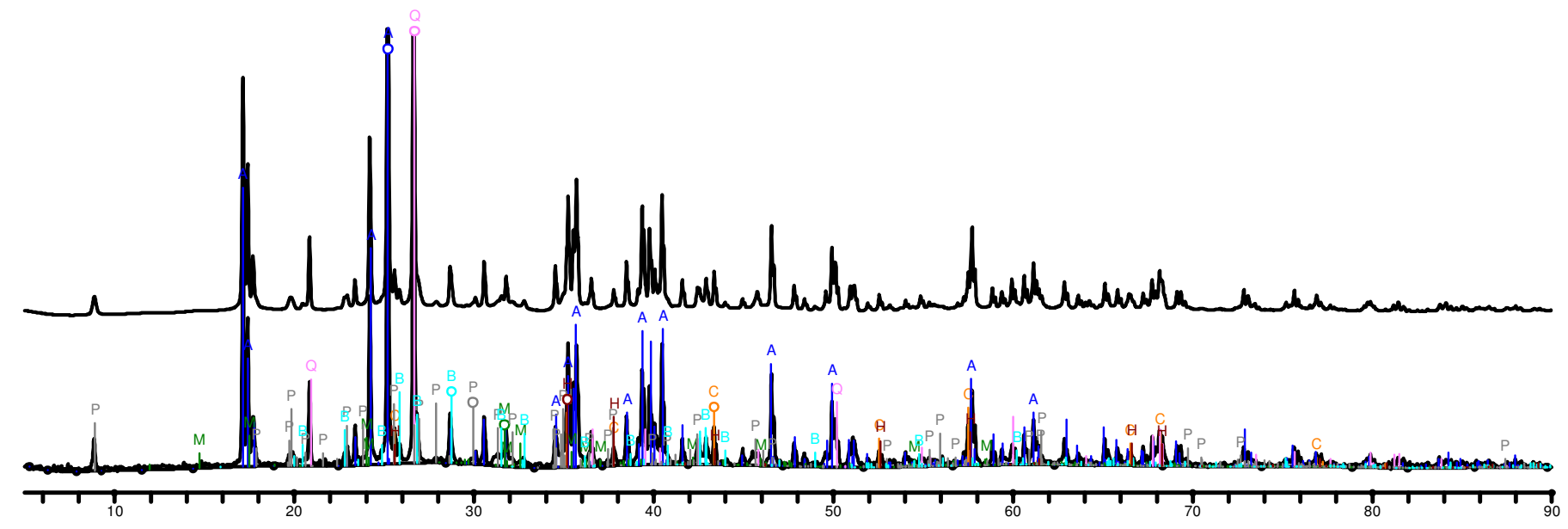

Figure 3. Semi-quantitative Mineralogy for Azurite Specimen. Output from Whole Pattern Fit analysis for the azurite specimen. 


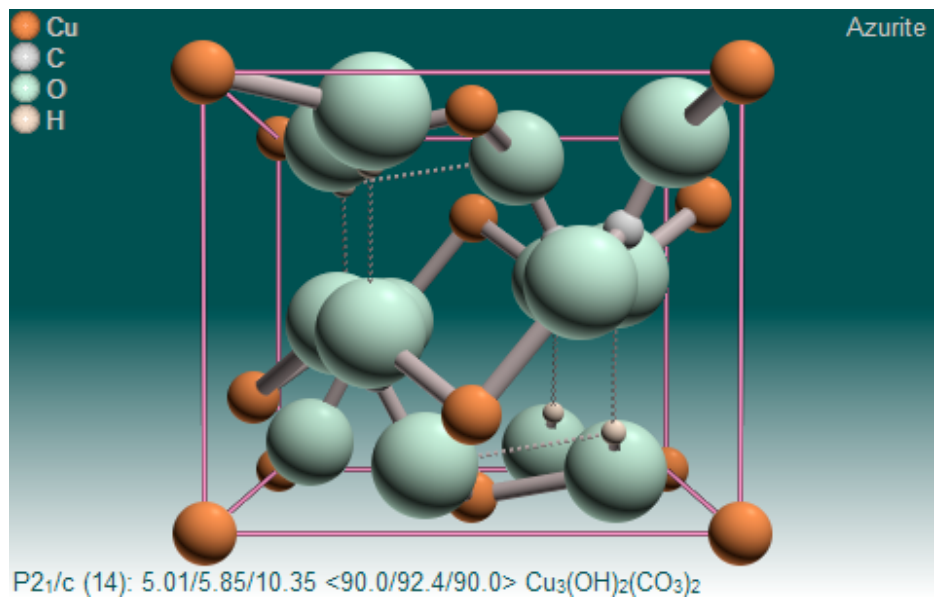

\begin{tabular}{|c|c|c|c|c|c|c|c|c|}
\hline & Orthorhombic $\mathrm{P} 2{ }_{1} / \mathrm{c}$ & $\mathrm{a}$ & $\mathrm{b}$ & $\mathrm{c}$ & Alpha & Beta & Gamma & $\begin{array}{c}\text { Cell } \\
\text { volume }\end{array}$ \\
\hline \multirow{3}{*}{ 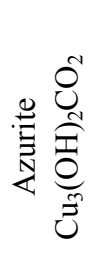 } & Ideal & 5.000 & 5.850 & 10.350 & 90.000 & 92.330 & 90.000 & 302.74 \\
\hline & Reported in literature & $\begin{array}{c}4.970- \\
5.011\end{array}$ & $\begin{array}{c}5.832- \\
5.850\end{array}$ & $\begin{array}{c}10.290- \\
10.353\end{array}$ & 90.000 & $\begin{array}{l}92.28- \\
92.43\end{array}$ & 90.000 & $\begin{array}{c}298.5- \\
303.2\end{array}$ \\
\hline & Measured & 5.009 & 5.846 & 10.345 & 90.000 & 92.447 & 90.000 & 302.95 \\
\hline
\end{tabular}

$\mathrm{a}, \mathrm{b}$, and $\mathrm{c}$ are axial lengths in angstroms

Alpha, Beta, Gamma are interaxial angles in degrees

Figure 4. Unit cell molecular model and unit cell parameters for azurite.

the black areas in the SEM micrograph of malachite (fig. $5 B$ ) are void spaces, which are connected through a network of microfractures.

\section{Sulfide Minerals Chalcopyrite and Bornite}

\section{Chalcopyrite}

Chalcopyrite is a copper iron sulfide $\left(\mathrm{CuFeS}_{2}\right)$. Although it is chemically similar to many copper sulfide minerals such as bornite $\left(\mathrm{Cu}_{5} \mathrm{FeS}_{4}\right)$, chalcocite $\left(\mathrm{Cu}_{2} \mathrm{~S}\right)$, covellite $(\mathrm{CuS})$, and digenite $\left(\mathrm{Cu}_{9} \mathrm{~S}_{5}\right)$, and has a structure similar to lenaite $\left(\mathrm{AgFeS}_{2}\right)$, chalcopyrite does not naturally form a solid solution with any other metal sulfide. Selenium can substitute for sulfur and a solid solution does exist between chalcopyrite and eskebornite $\left(\mathrm{CuFeSe}_{2}\right)$. More commonly cobalt, manganese, nickel, tin, and zinc randomly substitute, in low concentration, for copper and iron in chalcopyrite and are considered a contaminant.

The chalcopyrite sample is rich in mineral inclusions (figs. 9A-F): andradite garnet; sphalerite, a cobalt-ironarsenic sulfide, probably cobaltite (CoAsS); unnamed nickel-iron-cobalt-arsenic sulfides; bismuth-telluride minerals; and silver-bismuth-sulfide minerals. These accessory sulfide minerals commonly occur together along structural trends as partial fracture lining or partial void filling.

Leachate studies show a high concentration of cobalt in the leachate solution for this mineral (see Hageman, this volume), which may be a result of partial dissolution of the accessory cobalt-bearing sulfide minerals, but arsenic was below the leachate detection limit. However, arsenic is reported in the bulk chemistry results (Appendix C). Selenium was below the leachate detection limit $(<1 \mathrm{ppm})$ indicating this specimen did not contain any eskebornite.

The sample does not have a high degree of porosity, but void spaces exist and are connected through a microfracture network. Some fractures are partially filled by accessory sphalerite, nickel-, cobalt-, and arsenic-bearing sulfide minerals, bismuth tellurides, and sparse quartz, apatite, and calcite (figs. 9C, 9D). Sphalerite grains in void spaces have a high degree of liberation, and therefore, are more susceptible to the weathering influence of infiltrating oxygen and fluids.

The XRD scan of the specimen identified one accessory mineral (fig. 10A), a garnet with a composition near andradite $\left(\mathrm{Ca}_{3} \mathrm{Fe}_{2}^{+3}\left(\mathrm{SiO}_{4}\right)_{3}\right)$. Figure $10 \mathrm{~B}$ emphasizes the presence of the 


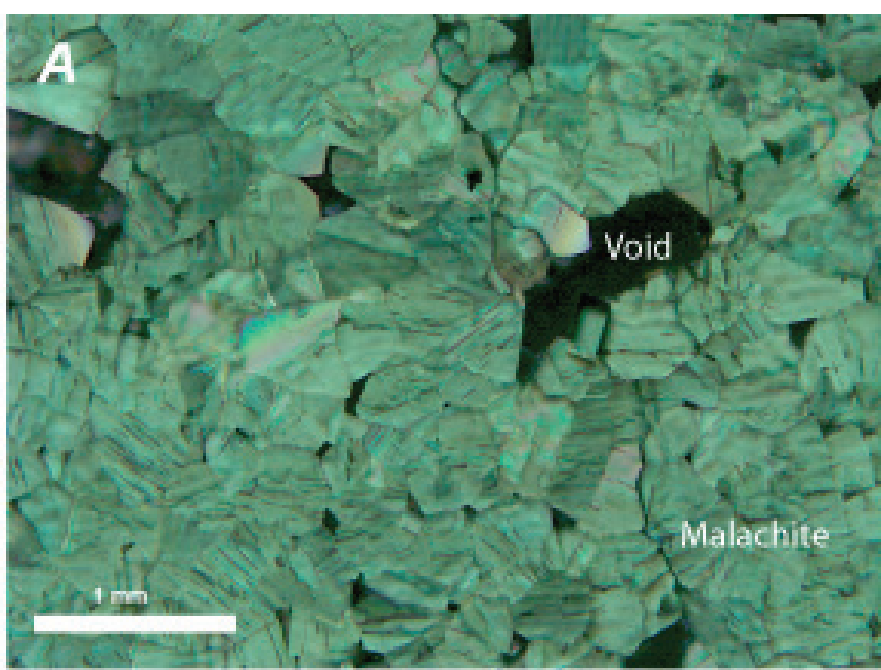

Figure 5. A-C. A. Thin section micrograph of malachite, showing strong coloration of the copper carbonate, and equant medium-grained crystal aggregates. Note that the morphology of malachite depicted in B-1 is acicular. B. SEM micrograph, showing the SEM backscatter micrograph to the left, and $C$. to the right the EMPA element intensity map showing the distribution of nickel concentrated in late-stage growth zones.
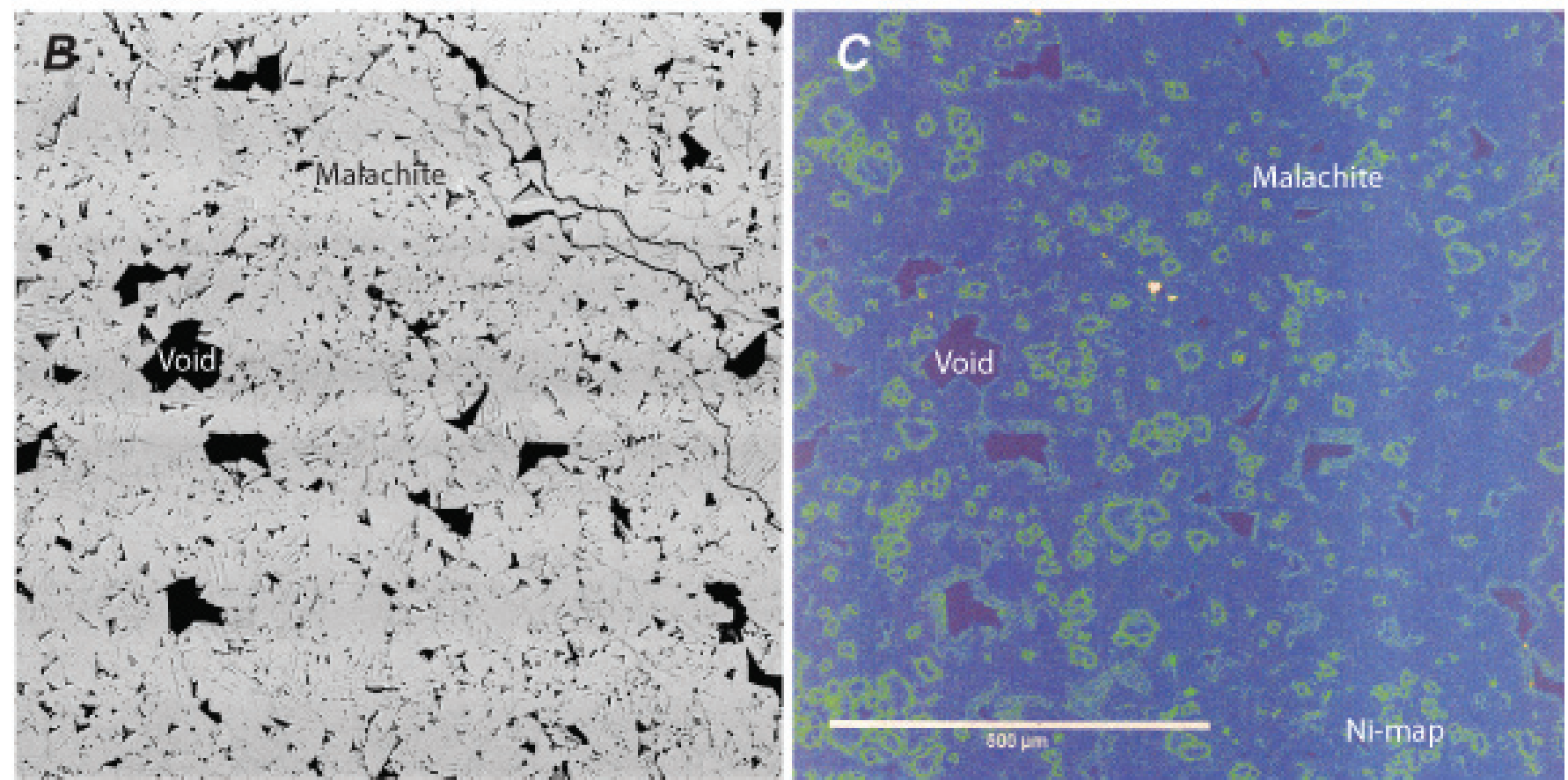

garnet. The crystalline portion of the sample was determined to be chalcopyrite (94 percent) and garnet (6 percent) (fig. 11).

In addition, the specimen contained an amorphous component estimated to be as large as 25 percent of the sample, most likely due to void filling materials as seen in figures $9 \mathrm{E}$ and 9F. The voids are filled with amorphous iron-rich materials including hematite and possible amorphous phosphates. The chalcopyrite phase within the specimen is crystalline and has a unit cell close to ideal (fig. 12).

The accessory zinc-, cobalt-, and silver-sulfide minerals were not detected or identified by XRD. These discrepancies most likely stem from sampling differences due to limited material. The sample submitted for XRD analysis was more homogeneous than the polished thin-section sample examined under the SEM. The approximately 3-5 percent of sulfide minerals such as cobaltite and sphalerite not detected by XRD analysis are important to identify because they may have ramifications for future acid rock drainage problems and metal release. After the study was complete, a portion of the thin-section billet was analyzed by XRD and the accessory minerals were observed in the XRD scan. This emphasizes that utilizing several techniques results in better characterization of mineralogy.

\section{Bornite}

Bornite in this specimen is hosted in potassium feldspar, identified by XRD as sanidine (fig. 13A, 13C). Bornite is intergrown and rimmed by chalcopyrite, suggesting a replacement texture (fig. 13C). Chalcopyrite also exhibits an exsolution texture in bornite (fig. 13D).

Bornite most commonly forms as a massive mineral ore and oxidizes easily to form copper oxides or hydroxides. 


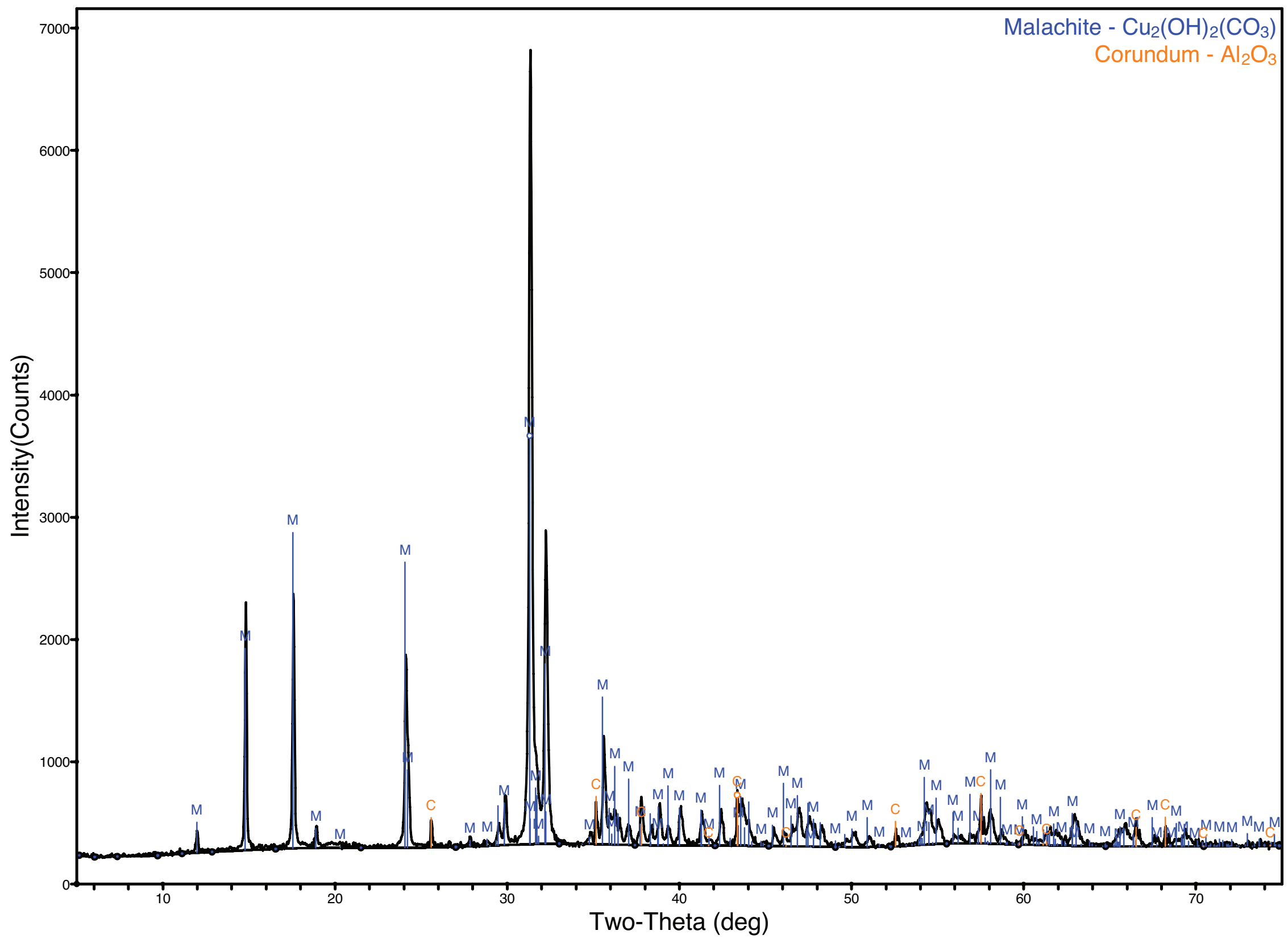




\section{Malachite with alumina internal standard}

Phase ID

Malachite - $\mathrm{Cu}_{2}(\mathrm{OH})_{2}\left(\mathrm{CO}_{3}\right)$
Space Group

$\mathrm{P} 2{ }_{1} / \mathrm{a}(14)$ a

9.47005 b

11.93503 c

3.23740
Alpha

90.000

Geta Gamma

$\begin{array}{ll}\text { Phase ID } & \text { Wt\% } \\ \square \text { Malachite }-\mathrm{Cu}_{2}(\mathrm{OH})_{2}\left(\mathrm{CO}_{3}\right) & 100.0 \\ \square \text { Corundum }-\mathrm{Al}_{2} \mathrm{O}_{3} & \end{array}$
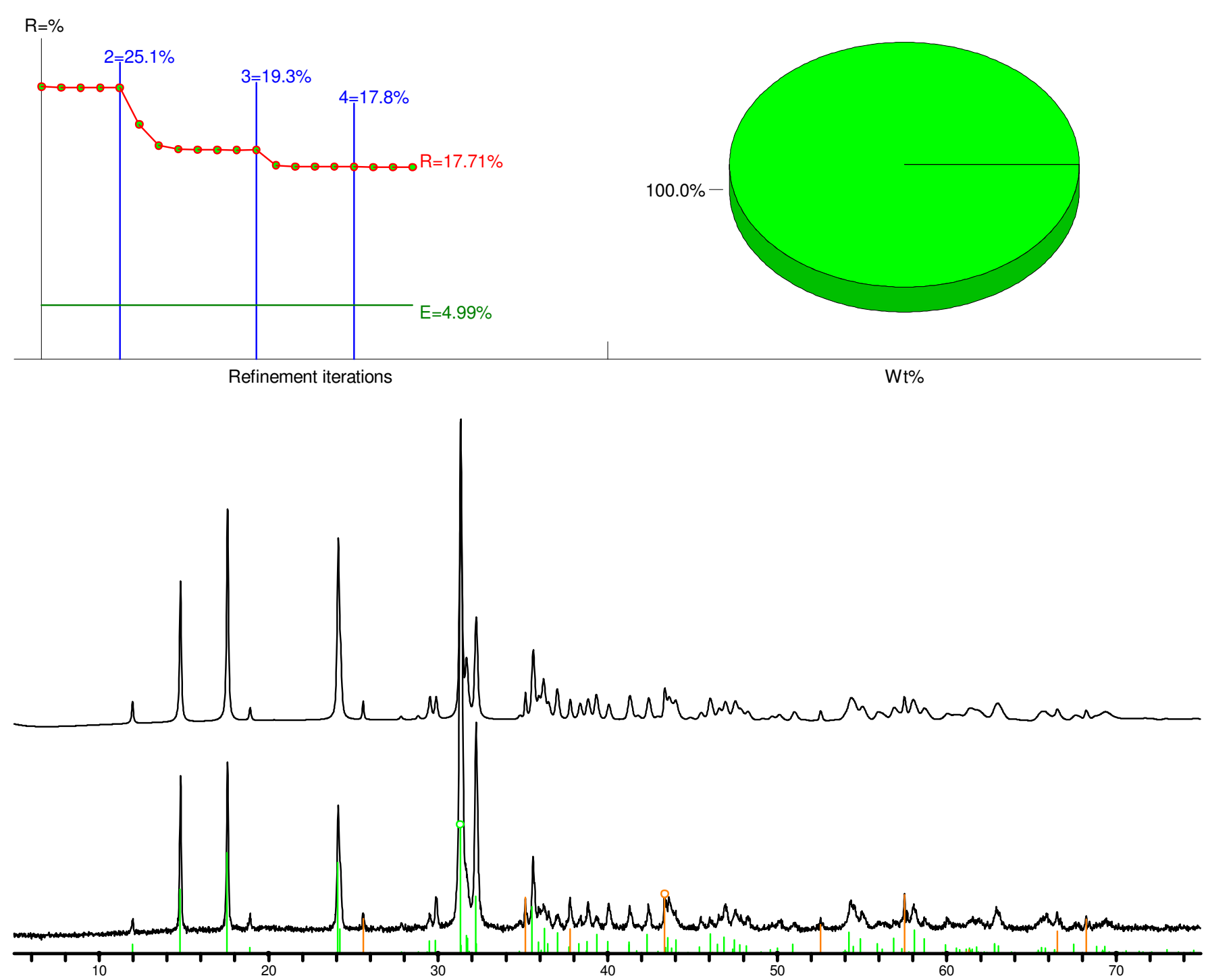

Figure 7. Semi-quantitative mineralogy for the malachite specimen. Output from Whole Pattern Fit analysis. 


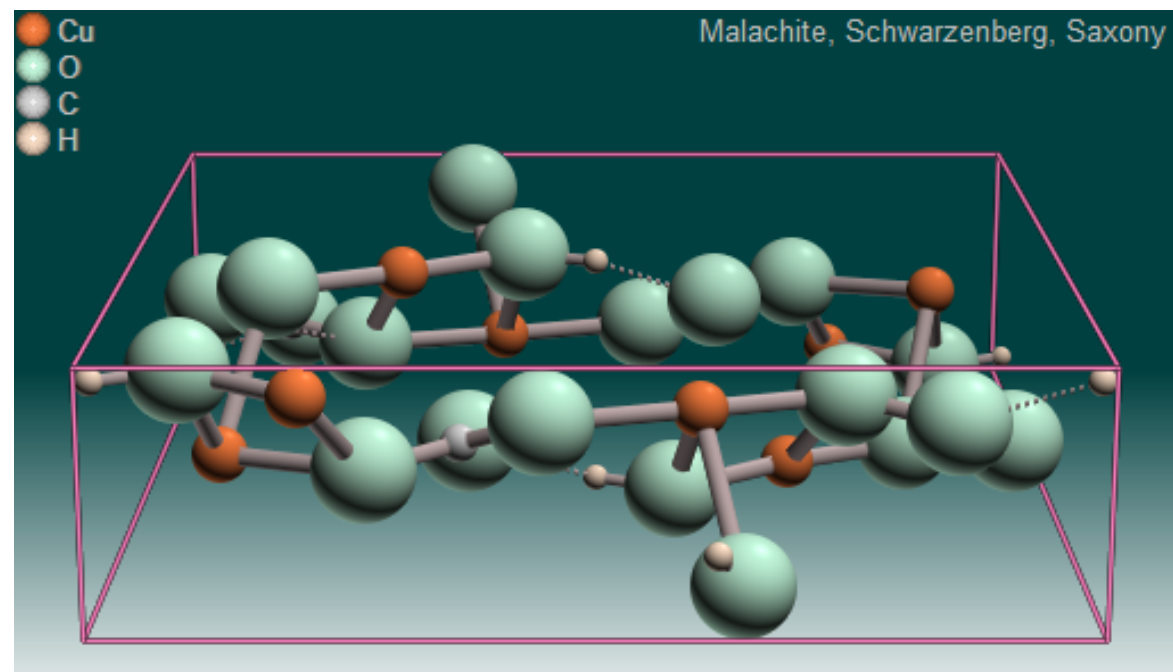

$\mathrm{P} 2{ }_{1} / \mathrm{a}(14): 9.5 / 11.97 / 3.24<90.0 / 98.8 / 90.0>\mathrm{Cu}_{2}(\mathrm{OH})_{2}\left(\mathrm{CO}_{3}\right)$

\begin{tabular}{|c|c|c|c|c|c|c|c|c|}
\hline & Monoclinic $\mathrm{P} 2{ }_{1} / \mathrm{a}$ & $\mathrm{a}$ & $\mathrm{b}$ & $\mathrm{c}$ & Alpha & Beta & Gamma & $\begin{array}{c}\text { Cell } \\
\text { volume }\end{array}$ \\
\hline \multirow{3}{*}{ 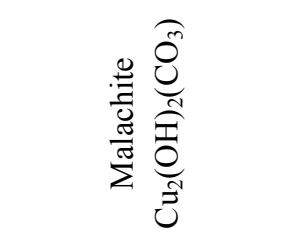 } & Ideal & 9.480 & 12.030 & 3.210 & 90.000 & 98.000 & 90.000 & 366.08 \\
\hline & $\begin{array}{l}\text { Reported in } \\
\text { literature }\end{array}$ & $\begin{array}{c}9.480- \\
9.502\end{array}$ & $\begin{array}{c}11.974- \\
12.030\end{array}$ & $\begin{array}{c}3.210- \\
3.240\end{array}$ & 90.000 & $\begin{array}{c}98.000- \\
98.8\end{array}$ & 90.000 & $\begin{array}{l}362.5- \\
366.08\end{array}$ \\
\hline & Measured & 9.470 & 11.935 & 3.237 & 90.000 & 98.642 & 90.000 & 365.86 \\
\hline $\begin{array}{c}\text { Glaukosphaerite } \\
(\mathrm{Cu}, \mathrm{Ni})_{2}\left(\mathrm{CO}_{3}\right)(\mathrm{OH})_{2} \\
\end{array}$ & & 9.34 & 11.93 & 3.07 & 90 & 90 & 90 & 342.08 \\
\hline $\begin{array}{c}\text { Kolwezite } \\
(\mathrm{Cu}, \mathrm{Co})_{2}\left(\mathrm{CO}_{3}\right)(\mathrm{OH})_{2}\end{array}$ & & 9.368 & 12.07 & 3.389 & 90 & 90.23 & 90 & 383.20 \\
\hline $\begin{array}{c}\text { Mcguinnessite } \\
(\mathrm{Cu}, \mathrm{Mg})_{2}\left(\mathrm{CO}_{3}\right)(\mathrm{OH})_{2}\end{array}$ & & 9.398 & 12.011 & 3.379 & 90 & 93.28 & 90 & 380.79 \\
\hline
\end{tabular}

$\mathrm{a}, \mathrm{b}$, and c are axial lengths in angstroms

Alpha, Beta, Gamma are interaxial angles in degrees

Figure 8. Unit cell molecular model and unit cell parameters for malachite.

Bornite does not form a solid solution series with any other metal sulfide. However, the metal-to-sulfur ratio in the mineral can vary allowing for high sulfur bornite phases (Brett and Yund, 1964). The sulfur stoichiometry can range from $\mathrm{S}_{4}$ to $\mathrm{S}_{4.12}$ in the bornite formula $\mathrm{Cu}_{5} \mathrm{FeS}_{4}$.

The XRD study shows the specimen has numerous accessory minerals (figs. $14 A$ and $14 B$ ) with the crystalline fraction composed of bornite ( 58 percent), minor amounts of chalcopyrite ( 9 percent), sanidine (12 percent) and sphalerite (13 percent), and trace amounts of quartz (4 percent) and pyrite (4 percent) (fig. 15).
There is also a significant amorphous component calculated to be 30 percent. Based on the appearance of the original sample, the high amorphous content appears to be poorly formed clays (feldspar alteration products) as well as oxidized bornite possibly produced during the preparation of the specimen for XRD analysis. The measured unit cell of bornite is slightly outside the normal range of crystal dimensions (fig. 16); however the total volume of the cell is normal. The a-axis is stretched longer $(10.971 \AA$ instead of $10.960 \AA)$ and the b-axis is shortened $(21.840 \AA$ instead of $21.910 \AA)$. The skew of the crystal cell is due to substitution of $\mathrm{Ag}$ for $\mathrm{Cu}$ in the 

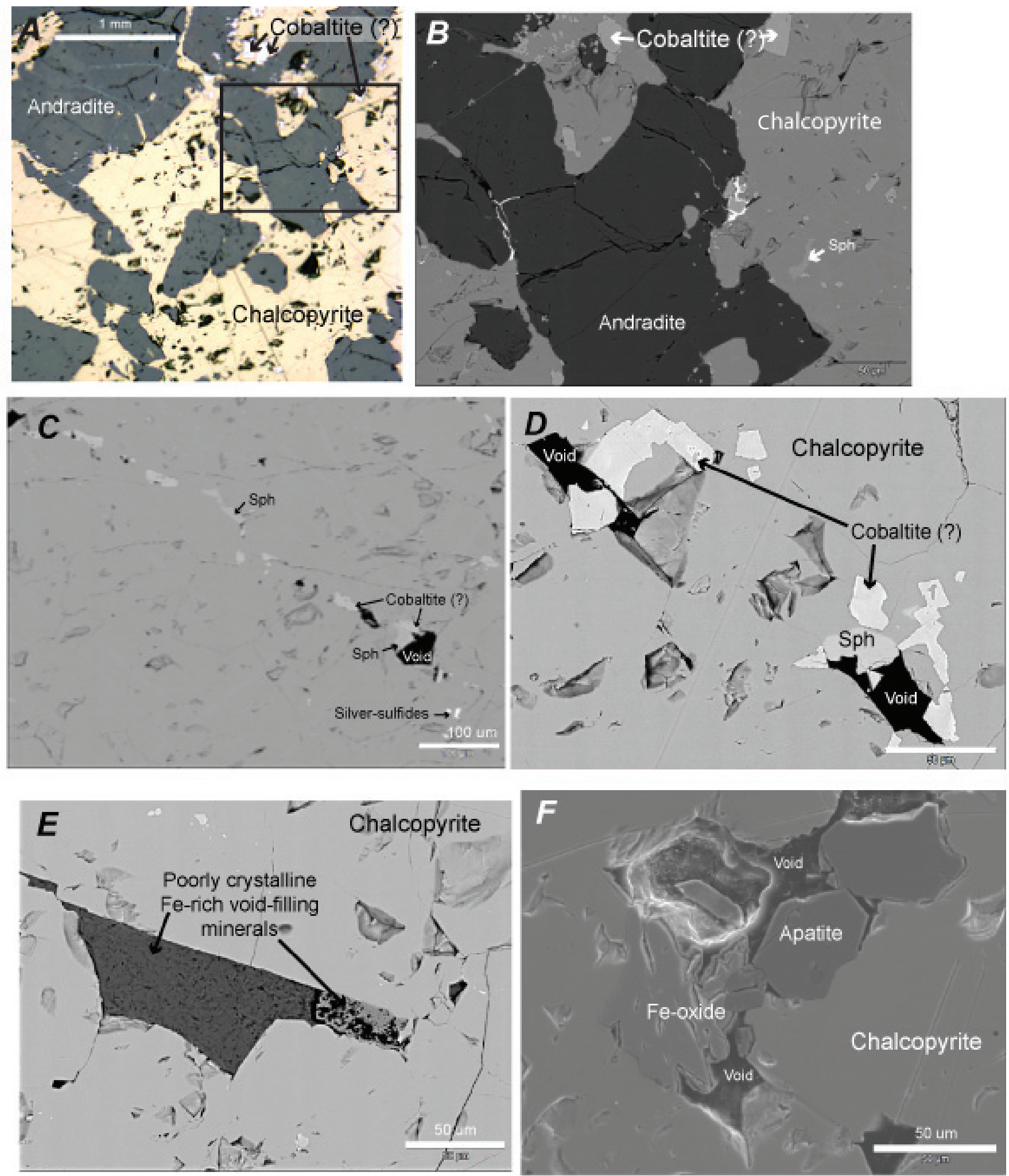

Figure 9A-F. A. Reflected light micrograph of chalcopyrite (yellow) with andradite (dark gray) and a cobalt-arsenic sulfide tentatively identified as cobaltite (pale pink). B. Enlarged backscatter SEM micrograph of area shown in the black square in fig. A.; note silver and bismuth sulfides (bright white areas) clustered at grain boundaries and filling fractures. $C$. Chalcopyrite specimen. SEM micrograph showing that accessory minerals commonly align along structural trends and occur in voids (sph = sphalerite). $D$. SEM micrograph showing sphalerite (sph) and cobaltite clustered in void areas. E. Void is filled by poorly crystalline Fe-rich minerals. F. Voids are commonly partially filled by accessory minerals such as apatite and hematite (?). 
Chalcopyrite with corundum internal standard

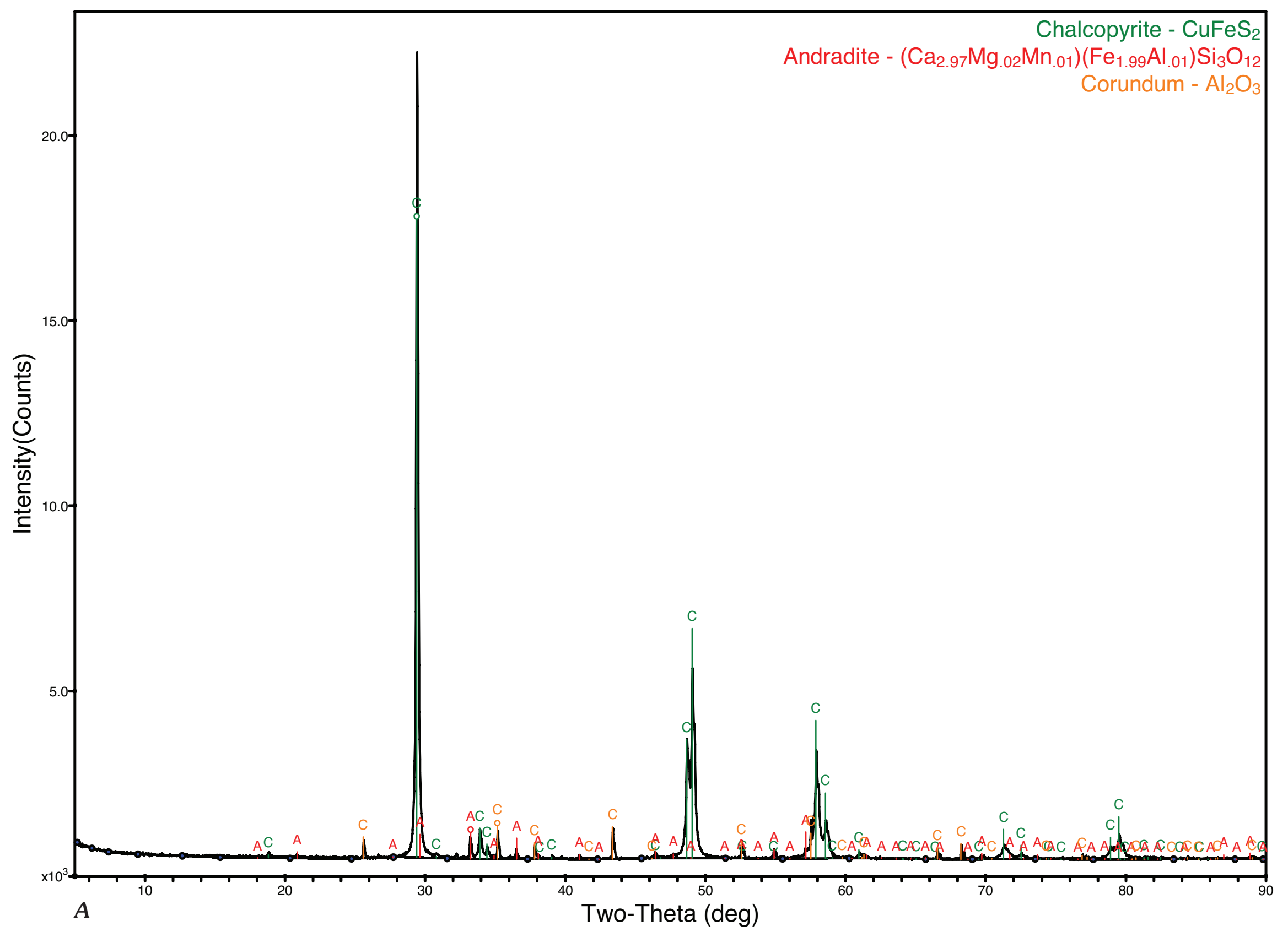

$\vec{\sigma}$

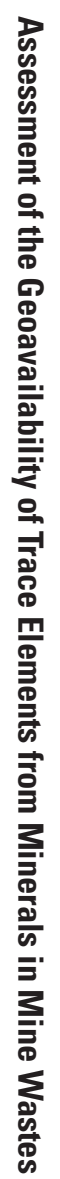

Figure $10 A$ and $10 B$ (above and facing page). XRD Scan of chalcopyrite. At top, full scale scan of chalcopyrite specimen showing accessory minerals; at bottom, intensity scale is expanded to show trace mineral phases. 


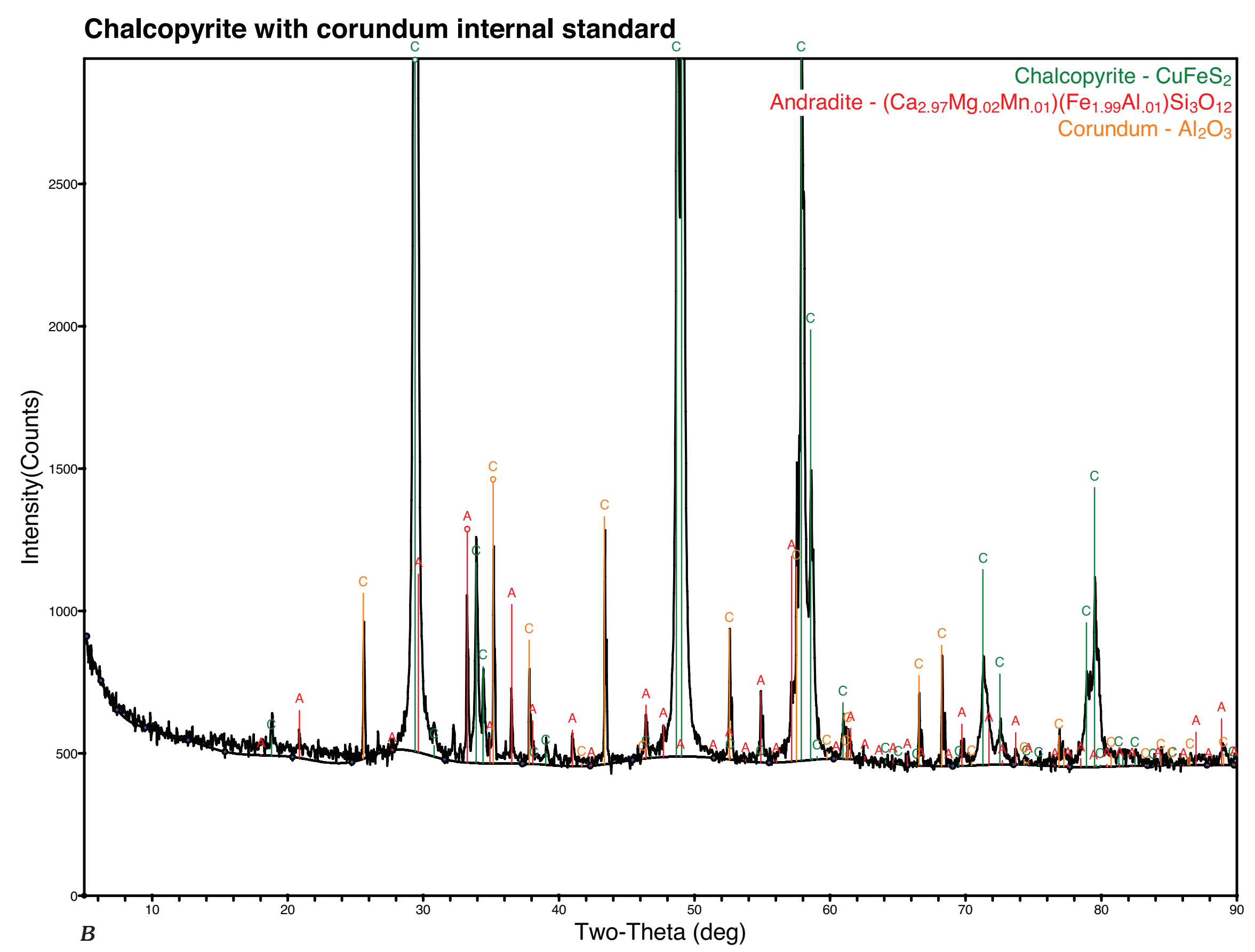

3.'. 


\section{Chalcopyrite with alumina internal standard}

\section{Phase ID}

Chalcopyrite - CuFeS 2
Space Group

I42d (122)

$\begin{array}{cccrrr}a & b & c & \text { Alpha } & \text { Beta } & \text { Gamma } \\ 5.28556 & 5.28556 & 10.41634 & 90.000 & 90.000 & 90.000\end{array}$

Corundum $-\mathrm{Al}_{2} \mathrm{O}_{3}$

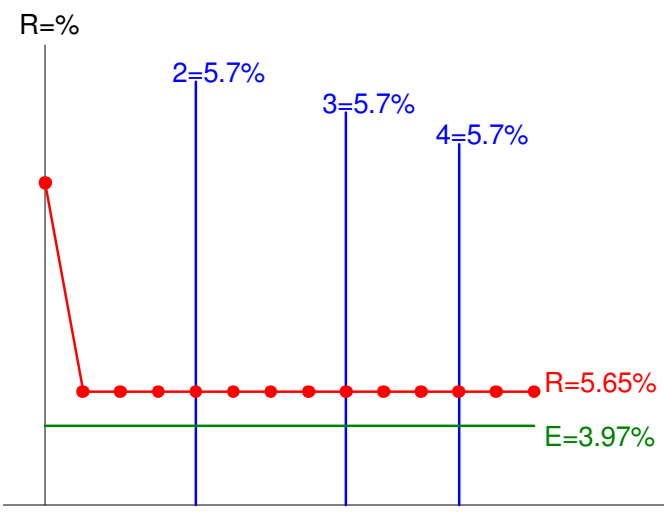

Refinement iterations
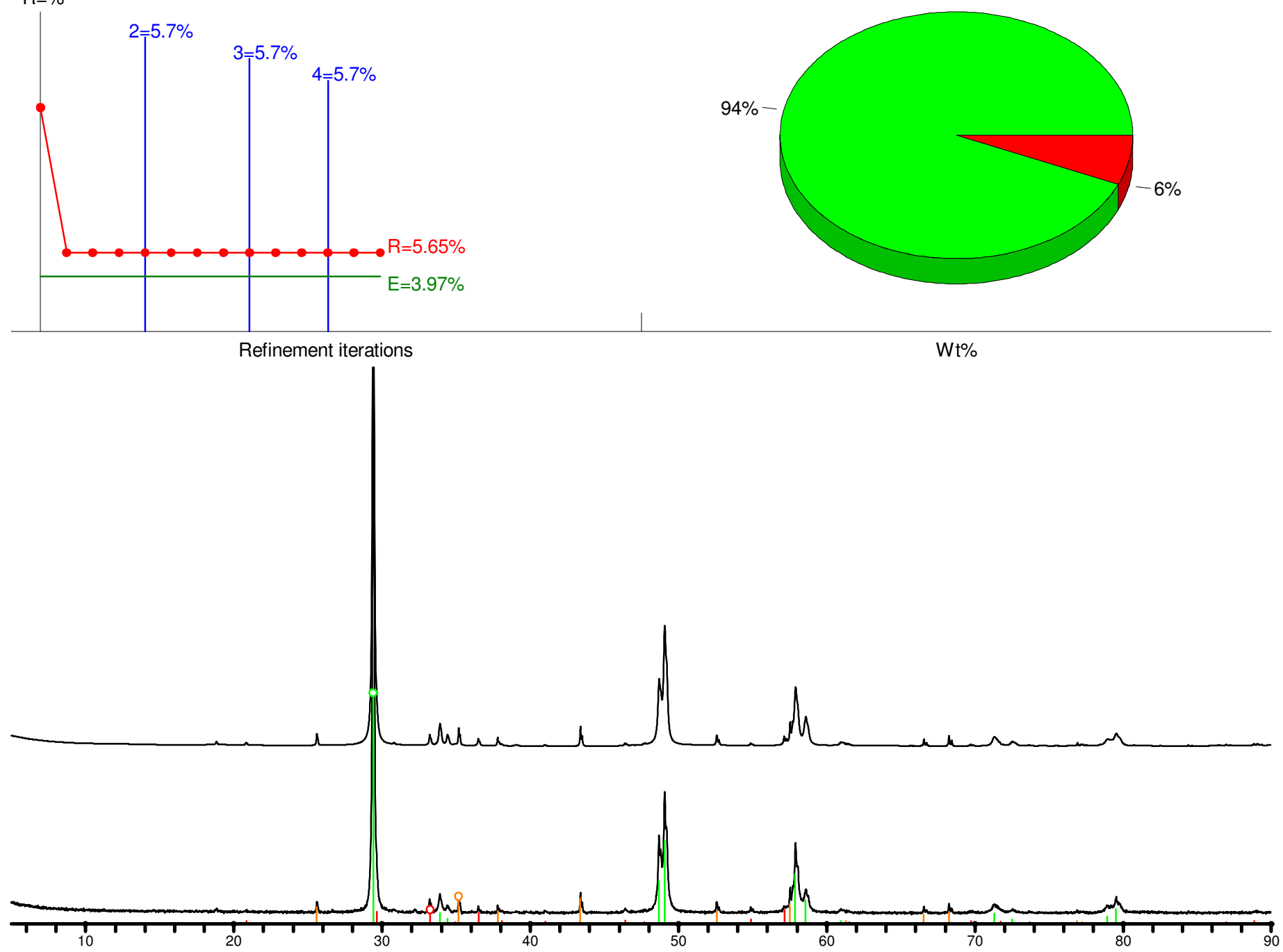

Figure 11. Semi-quantitative mineralogy for the chalcopyrite specimen. Output from Whole Pattern Fit. 


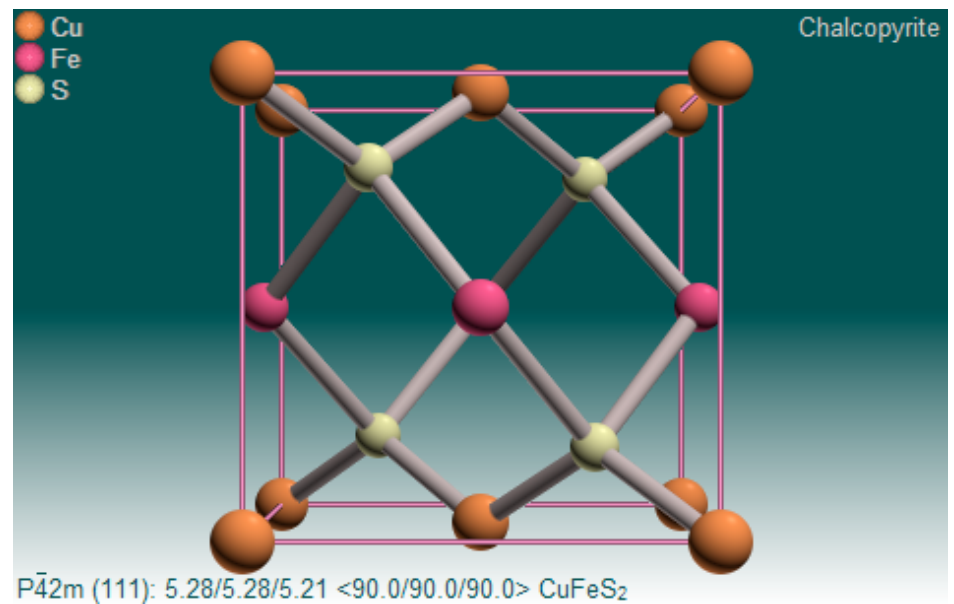

\begin{tabular}{|c|c|c|c|c|c|c|c|c|}
\hline & Tetragonal I42d & $\mathrm{a}$ & $\mathrm{b}$ & $\mathrm{c}$ & Alpha & Beta & Gamma & $\begin{array}{c}\text { Cell } \\
\text { volume }\end{array}$ \\
\hline \multirow{3}{*}{ 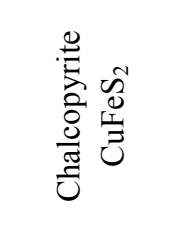 } & Ideal & 5.289 & 5.289 & 10.423 & 90.000 & 90.000 & 90.000 & 291.57 \\
\hline & $\begin{array}{c}\text { Reported in } \\
\text { literature }\end{array}$ & $\begin{array}{c}5.277- \\
5.289 \\
\end{array}$ & $\begin{array}{c}5.277- \\
5.289 \\
\end{array}$ & $\begin{array}{c}10.409- \\
10.423 \\
\end{array}$ & 90.000 & 90.000 & 90.000 & $\begin{array}{r}290.2- \\
291.6 \\
\end{array}$ \\
\hline & Measured & 5.286 & 5.286 & 10.416 & 90.000 & 90.000 & 90.000 & 291.04 \\
\hline $\begin{array}{c}\text { Eskebornite } \\
\mathrm{CuFeSe}_{2}\end{array}$ & & 5.53 & 5.53 & 11.049 & 90 & 90 & 90 & 337.9 \\
\hline
\end{tabular}

$\mathrm{a}, \mathrm{b}$, and $\mathrm{c}$ are axial lengths in angstroms

Alpha, Beta, Gamma are interaxial angles in degrees

Figure 12. Unit cell molecular model and unit cell parameters for chalcopyrite.

structure. Microprobe analysis (table 1) reveals $2.2 \mathrm{wt} \% \mathrm{Ag}$ is substituting for $\mathrm{Cu}$. The $\mathrm{Ag}-\mathrm{S}$ bond is slightly longer than the $\mathrm{Cu}-\mathrm{S}$ bond, causing the distortion which may lead to increased solubility of the bornite.

As demonstrated in the chalcopyrite sample, SEM reveals the presence of fine-grained accessory sulfide minerals that were not detected by XRD. Accessory minerals indicated by SEM are galena (up to $25 \mu$ in diameter) and iron-, bismuth-, and silver-sulfide minerals (up to $5 \mu$ in diameter). These accessory sulfide minerals commonly occur along the boundaries between bornite and chalcopyrite or as fracture fill. Transmitted light shows the presence of at least one other mineral phase, possibly a pyroxene. 


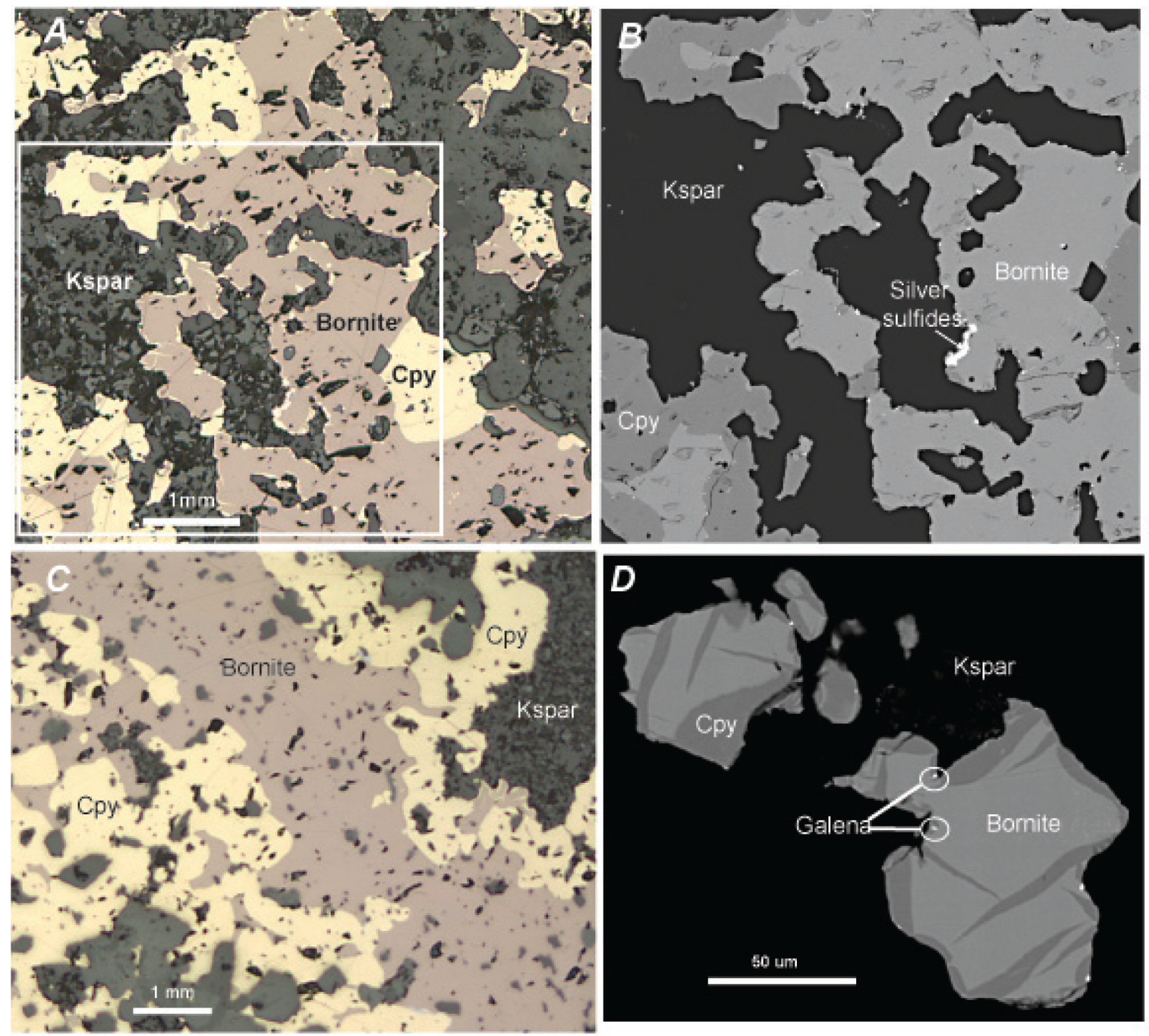

Figure $13 \boldsymbol{A}-\boldsymbol{D}$. A. Reflected light micrograph showing bornite (pink-bown) and chalcopyrite (yellow) in a quartz and potassium feldspar matrix (dark gray). Chalcopyrite partially rims bornite (Cpy = chalcopyrite; Kspar = potassium feldspar). B. Enlarged SEM backscatter image of area in the white square in figure $A$ showing light gray bornite, medium gray chalcopyrite. Bright white areas are galena, silver suflides, and silver-, nickel-sulfide minerals. $C$. Reflected light micrograph showing textural relationship between bornite and chalcopyrite. Pinkish-brown bornite in the center and islands of bornite within yellow chalcopyrite suggests that bornite is partially replaced by chalcopyrite. D. Backscatter SEM micrograph showing exsolution ("flame") textures between bornite and chalcopyrite. All micron-size bright spots in the image are galena grains (white circles). 


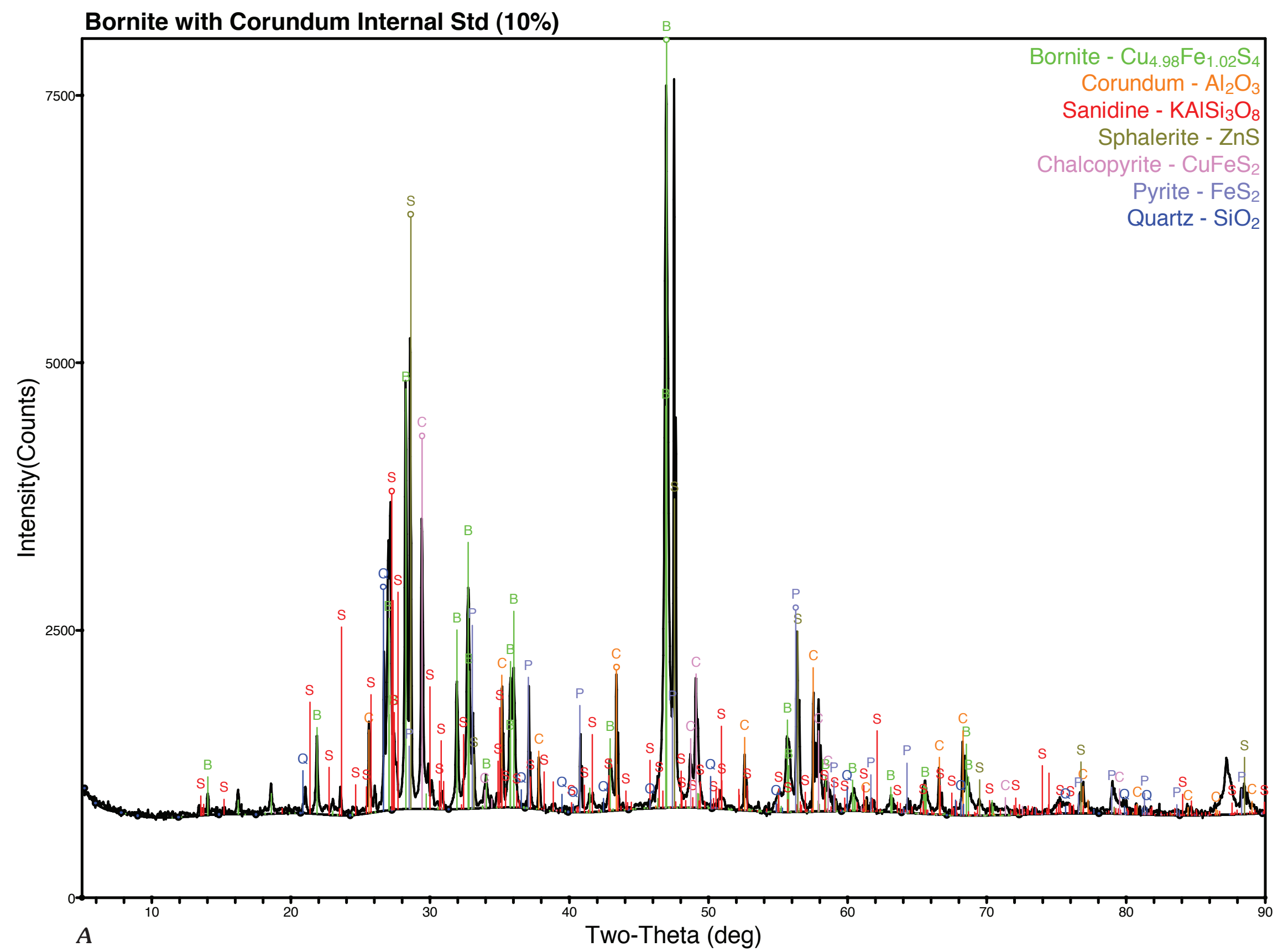

豙

Figure $14 A$ and $14 B$ (above and next page). XRD scan of bornite. At top, full scale scan of bornite specimen showing accessory minerals; at bottom, intensity scale is expanded to show trace mineral phases. 
Bornite with corundum internal standard

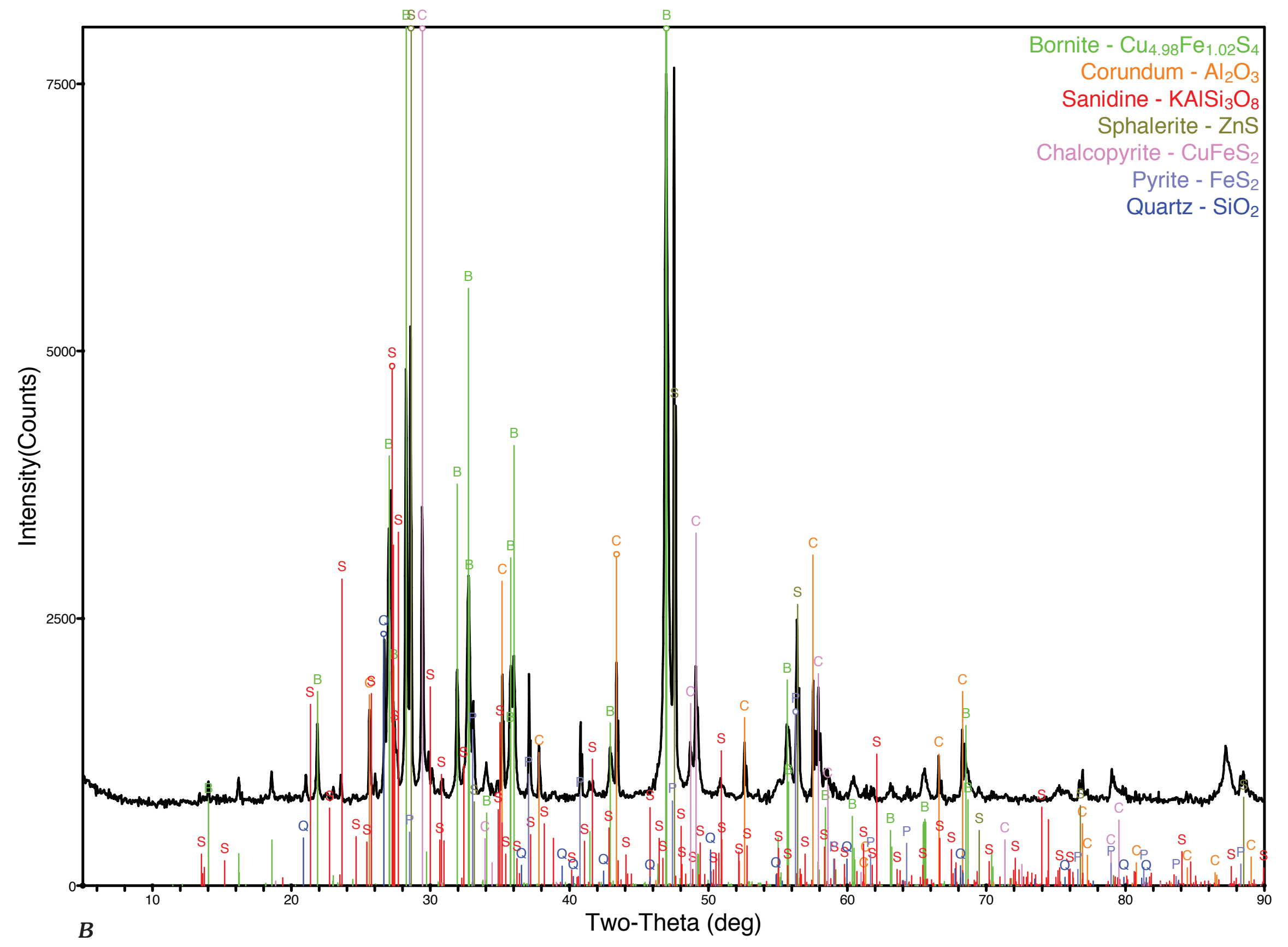

ก

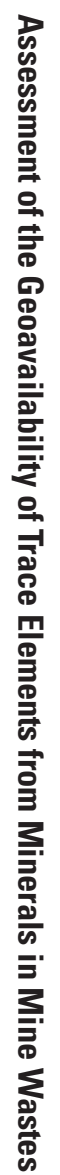

Two-Theta (deg) 


\section{Bornite with alumina internal standard}

Phase ID

Bornite - $\mathrm{Cu}_{4.98} \mathrm{Fe}_{1.02} \mathrm{~S}_{4}$
Space Group

Pbca (61) a 10.97103 b

21.83995
C

10.94688
Alpha

90.000

Beta 90.000

Gamma 90.000
Phase ID (7)

Bornite - $\mathrm{Cu}_{4.98} \mathrm{Fe}_{1.02} \mathrm{~S}_{4}$

Sanidine - $\mathrm{K}\left(\mathrm{AlSi}_{3} \mathrm{O}_{8}\right)$

Sphalerite - ZnS

Chalcopyrite - $\mathrm{CuFeS}_{2}$

Pyrite - $\mathrm{FeS}_{2}$

Quartz - $\mathrm{SiO}_{2}$

Corundum $-\mathrm{Al}_{2} \mathrm{O}_{3}$

$\begin{array}{lcr}\text { Source } & \text { l/lc } & \text { Wt\% } \\ \text { FIZ\#1963 } & 1.38(0 \%) & 58 \\ \text { FIZ\#80793 } & 0.88(0 \%) & 12 \\ \text { PDF\#97-007-7090 } & 6.61(0 \%) & 13 \\ \text { PDF\#97-000-2518 } & 6.74(0 \%) & 9 \\ \text { JCS\#363 } & 3.07(0 \%) & 4 \\ \text { PDF\#98-000-0369 } & 4.21(0 \%) & 4\end{array}$

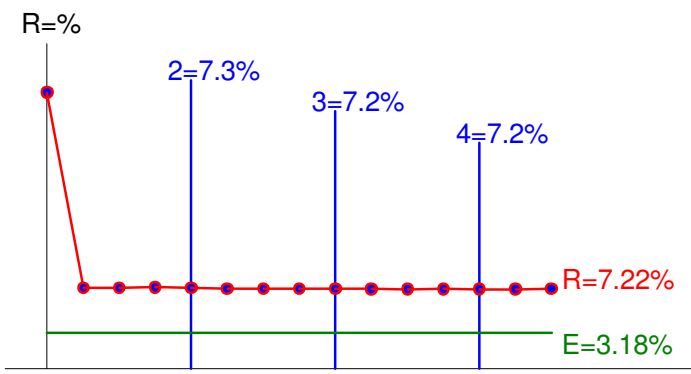

Refinement iterations
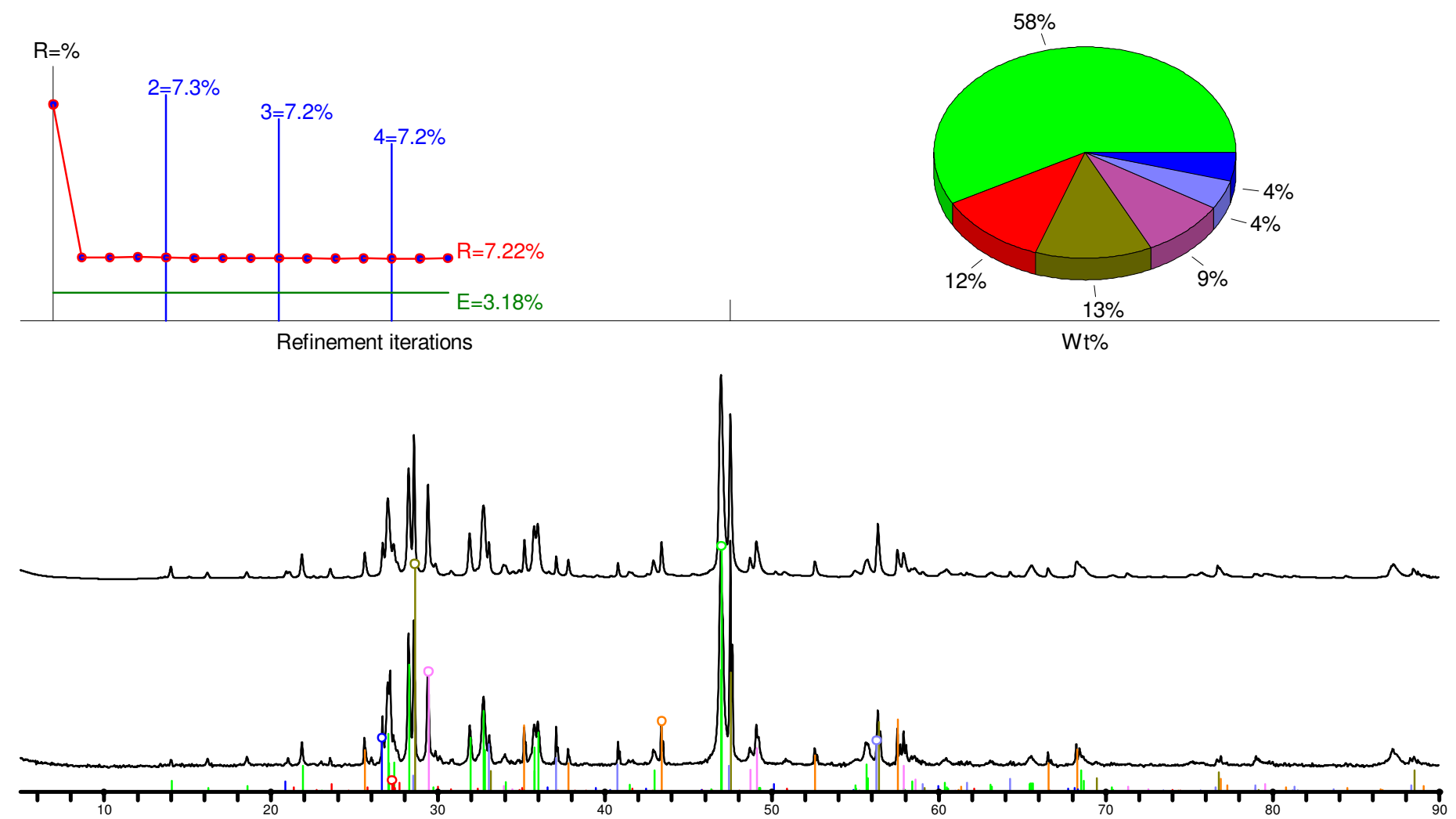

Figure 15. Semi-quantitative mineralogy for the bornite specimen. Output from Whole Pattern Fit. 


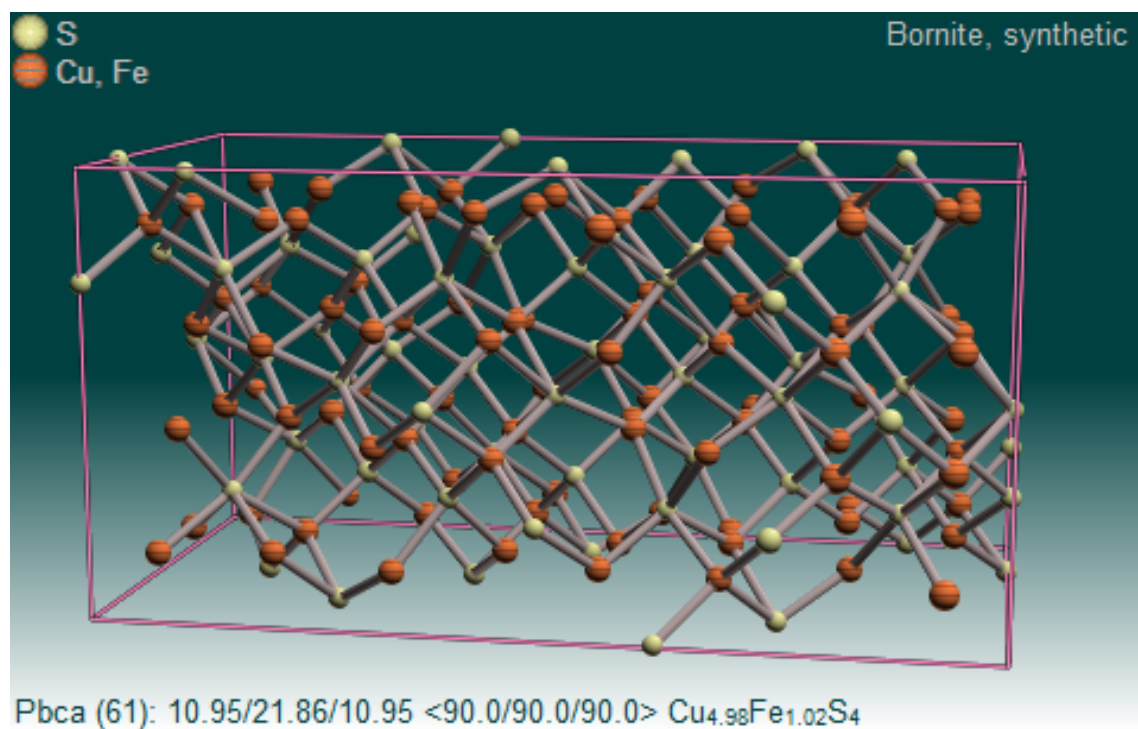

\begin{tabular}{|c|c|c|c|c|c|c|c|c|}
\hline & Orthorhombic Pbca & $\mathrm{a}$ & $\mathrm{b}$ & $\mathrm{c}$ & Alpha & Beta & Gamma & $\begin{array}{c}\text { Cell } \\
\text { volume }\end{array}$ \\
\hline \multirow{3}{*}{ 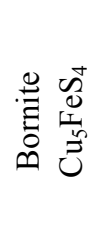 } & Ideal & 10.960 & 21.910 & 10.960 & 90.000 & 90.000 & 90.000 & 2631.86 \\
\hline & $\begin{array}{l}\text { Reported in } \\
\text { literature }\end{array}$ & $\begin{array}{c}10.940- \\
10.960\end{array}$ & $\begin{array}{c}21.862- \\
21.910\end{array}$ & $\begin{array}{c}10.940- \\
10.960\end{array}$ & 90.000 & 90.000 & 90.000 & $\begin{array}{c}2618.68- \\
2631.86\end{array}$ \\
\hline & Measured & 10.971 & 21.840 & 10.947 & 90.000 & 90.000 & 90.000 & 2622.85 \\
\hline
\end{tabular}

$\mathrm{a}, \mathrm{b}$, and c are axial lengths in angstroms

Alpha, Beta, Gamma are interaxial angles in degrees

Figure 16. Unit cell molecular model and unit cell parameters for bornite.

\section{Summary}

Petrographic, SEM, and EMPA studies of the mode of occurrence of trace metals are important because trace metals affect the chemical and physical behavior of a mineral, especially its solubility under weathering conditions in a mine-waste pile (Diehl and others, 2007). Microanalytical techniques are useful for (1) identifying mineral inclusions; (2) measuring the grain size of minerals and identifying degrees of crystallinity of individual minerals, both of which are important physical properties that influence stability and solubility; (3) recognizing preferred groupings of minerals (for example, mineral assemblages); (4) determining the degree of sulfide liberation, a good example of which is the occurrence of sphalerite in and around voids not encased within the chalcopyrite study specimen; and (5) locating mineralogic residence of trace elements.

SEM and XRD studies complement one another to produce a comprehensive summary of mineralogy in a sample.

Microanalytical data aid in explaining geochemical results such as element occurrence and concentration in leachate solutions. Each $\mathrm{Cu}$-bearing mineral sample in this study hosts trace-to-minor elements; the SEM micrographs and EMPA element maps reveal whether the trace elements are due to mineral inclusions, or whether the trace elements are distributed in the lattice structure of the mineral. Elemental chemistry detected under SEM analysis was corroborated by the bulk chemistry ICP analysis discussed in the following section. XRD studies revealed strains on the crystal lattice which may lead to increased solubility. 


\section{Bulk, Leachate, and Acid-Base Accounting Geochemical Study of Four Copper Bearing Minerals}

\author{
Bulk geochemistry for four Cu-bearing minerals, Appendix C \\ Leachate chemistry composition, Appendix D
}

Author: Philip L. Hageman

\section{Introduction-Bulk Sample Chemistry}

The bulk major-, minor-, and trace-element composition of the samples used in this study are essential to understanding trace-element mobility under various environmental conditions. The four mineral samples (azurite, chalcopyrite, bornite, and malachite) were prepared, digested, and analyzed for major, minor, and trace elements ICP-MS (Lamothe and others, 2002). Mercury was determined using coldvapor atomic fluorescence (CVAFS) (Hageman, 2007b). In addition, the malachite and azurite samples were analyzed for total carbon using the method described in Brown and Curry (2002a), and the bornite and chalcopyrite samples were analyzed for total sulfur by induction furnace using Brown and Curry (2002b). Complete bulk geochemical results are in Appendix C.

\section{Bulk Sample Digestion Methods}

The digestion of the samples for total carbon, total sulfur, and mercury determination was accomplished using the methods cited above. However, modified procedures were needed to digest the samples for analysis using ICP-MS.
Modification was required because it is not possible to completely digest concentrated mineral samples using the standard three-acid ICP-MS digestion method (P. Lamothe, personal commun., 2010). Thus, the following protocol was used:

Approximately $100 \mathrm{mg}$ of prepared sample was weighed to the nearest $0.1 \mathrm{mg}$ and was placed in a $30 \mathrm{~mL}$ Teflon ${ }^{\circledR}$ vial. Four $\mathrm{mL}$ concentrated hydrofluoric acid (HF) and $2 \mathrm{~mL}$ concentrated nitric acid (HNO3) was then added to each vial. After mixing, the vials were placed on a hot plate and heated at $100{ }^{\circ} \mathrm{C}$ until dry. The vials were then removed from the hot plate and cooled. Three $\mathrm{mL}$ of concentrated hydrochloric acid $(\mathrm{HCl}), 1 \mathrm{~mL}$ concentrated $\mathrm{HNO} 3$, and $1 \mathrm{~mL}$ concentrated perchloric acid $(\mathrm{HClO} 4)$ were added to the dried residues. The vials were returned to the hot plate and heated at $100{ }^{\circ} \mathrm{C}$ until dry. The vials were again removed from the hot plate and cooled. Exactly $1.00 \mathrm{~mL}$ of concentrated HNO3 and $9.00 \mathrm{~mL}$ of deionized water (DI) were added to each vial. The vials were then capped and shaken. Just prior to analysis, the vials were warmed in an oven at $90{ }^{\circ} \mathrm{C}$ for one hour. The vials were then removed from the oven and cooled. An aliquot of each sample solution was diluted 1:10 (one part sample: ten parts diluent) with 2 percent $\mathrm{HNO}_{3}$.

The digestion procedure described above has been shown to completely dissolve a wide range of minerals including pyrite, chalcopyrite, pyrrhotite, covellite, enargite, azurite, malachite, bornite, sphalerite, and pentlandite.

\section{Bulk Chemistry Summary}

Solid-phase bulk geochemistry will be summarized in this section. Complete analytical results for all bulk analyses are given in Appendix C.

The ICP-MS results show that bulk copper concentrations were similar (fig. 17) in the azurite, chalcopyrite, bornite, and

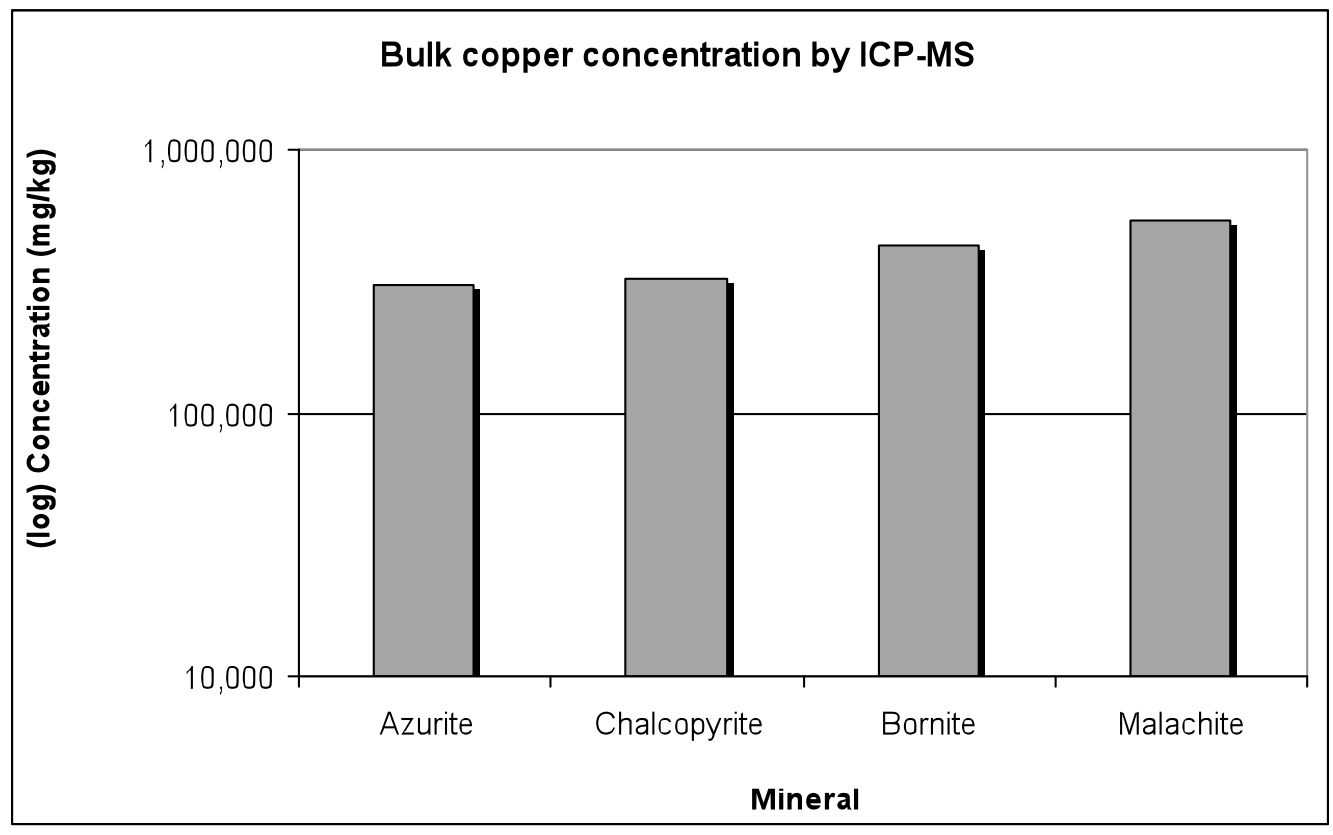

Figure 17. Bulk copper concentration (ICP-MS) of four mineral samples. 
malachite samples. Total copper concentration in the samples ranged from a high of $534,000 \mathrm{mg} / \mathrm{kg}$ in the malachite sample to a low of $305,000 \mathrm{mg} / \mathrm{kg}$ in the azurite. For the four copperbearing minerals, total bulk copper concentration fell in the following order: malachite $>$ bornite $>$ chalcopyrite $>$ azurite.

Bulk geochemistry varied widely in the four samples. Figures 18-21 show plots of selected major- and trace-element concentration for each mineral.

\section{Introduction-Leaching Studies}

Leaching studies were conducted in order to identify, characterize, and model constituents that are mobilized from these minerals under environmental conditions. For this study, prepared splits $(<2 \mathrm{~mm})$ of all four samples were leached using four common leach tests. The tests selected for this study all provide specific geochemical information
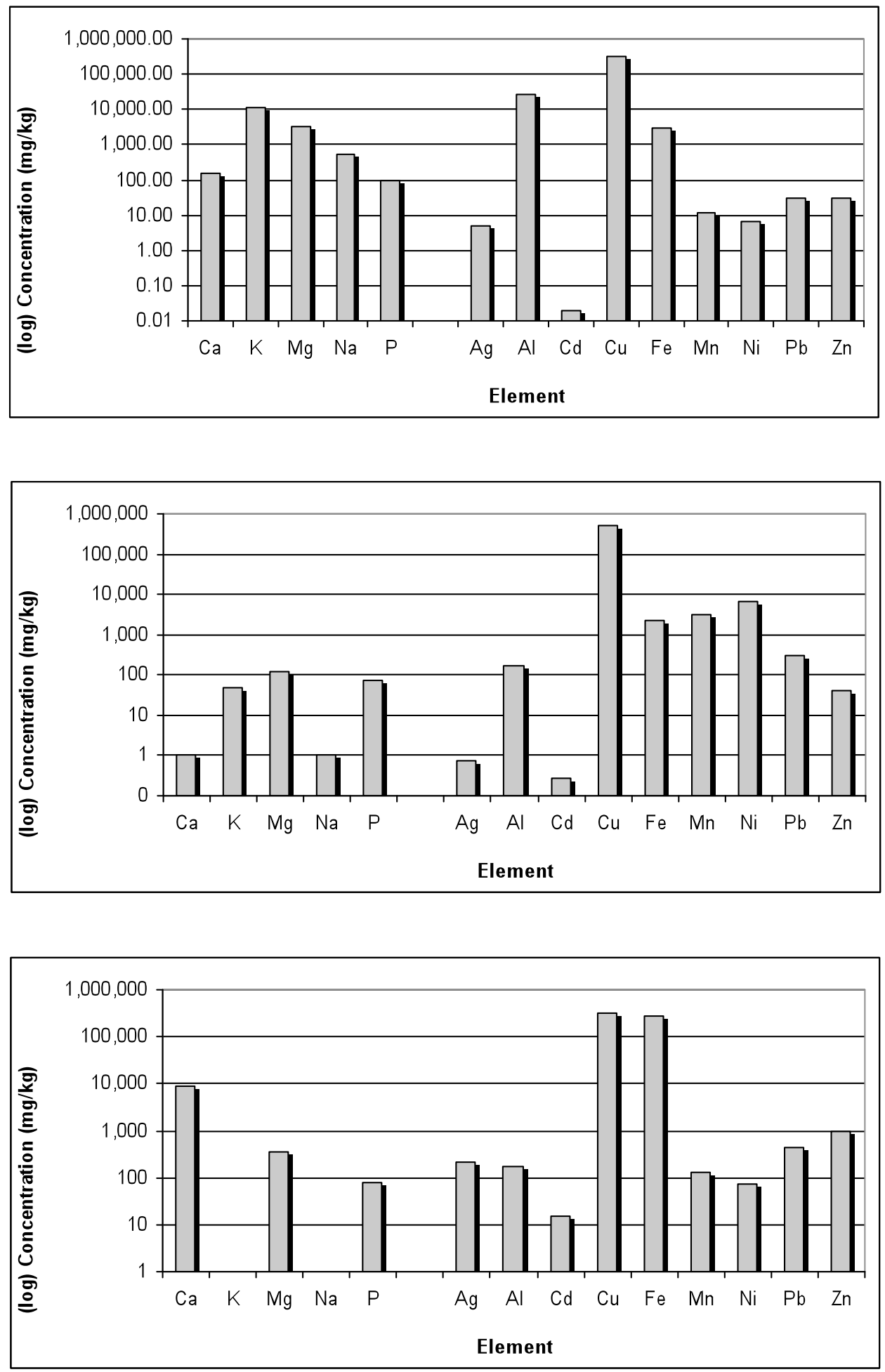

Figure 18. Selected element profile of azurite

Figure 19. Selected element profile of malachite

Figure 20. Selected element profile of chalcopyrite 


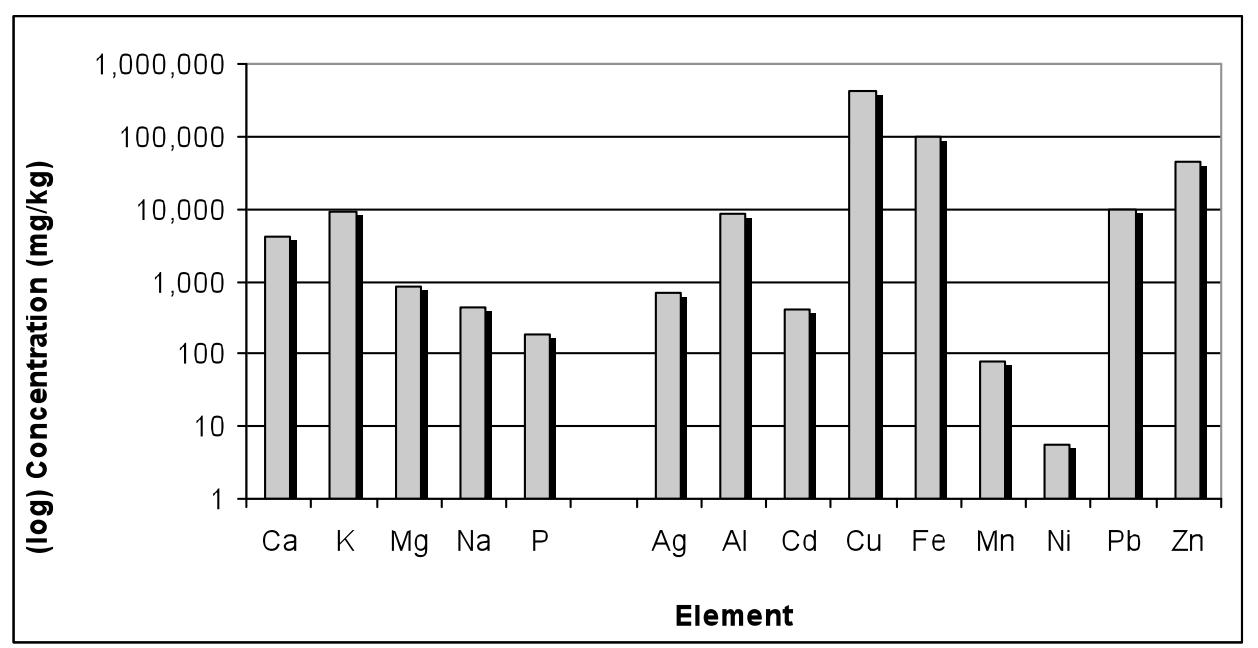

Figure 21. Selected element profile of bornite

that is useful to help understand how the minerals would act if leached in the natural environment. The following leaching tests were used in this study (a comprehensive list of experimental parameters for each procedure is given in table $2)$ :

- $\quad$ Field Leach Test (FLT) (Hageman, 2007a)

- U.S. Environmental Protection Agency Method 1312, Synthetic Precipitation Leaching Procedure (SPLP), leachate $\mathrm{pH} 4.2$ and leachate $\mathrm{pH} 5.0$ versions of this test (USEPA, 1994)

- U.S. Environmental Protection Agency Method 1311, Toxicity Characteristic Leaching Procedure (TCLP), (USEPA, 2004).
Each of the leaching tests used in this study provide unique geochemical information about the minerals. The rationale for using each method is given below.

- $\quad$ USGS Field Leach Test (FLT): This leach test uses deionized water (ASTM Type II) and a short agitation period ( 5 minutes) to assess the readily water soluble, water reactive characteristics of a sample. This test is very effective in identifying the constituents that would be mobilized due to leaching by natural precipitation. An important feature of the FLT is that it uses a 20:1 leaching ratio (leachant/solid). This ratio avoids leachate saturation while simultaneously providing enough leachate (leach solution) to complete all the desired analyses. Use of this ratio

Table 2. Leaching parameters for the leaching procedures used in this study including the U.S. Geological Survey (USGS) Field Leach Test (FLT), modified versions of the Environmental Protection Agency Method 1312 (SPLP), and the Environmental Protection Agency Method 1311 (TCLP).

$[<$, less than; $\approx$, approximately; USEPA, U.S. Environmental Protection Agency; SPLP, synthetic Precipitation Leaching Procedure; TCLP, Toxicity Characteristic Leaching Procedure]

\begin{tabular}{|c|c|c|c|}
\hline Characteristic & USGS FLT & Modified USEPA 1312 SPLP & Modified USEPA 1311 TCLP \\
\hline Test type & Batch & Batch & Batch \\
\hline Leachate to solid ratio & $20: 1$ & $20: 1$ & $20: 1$ \\
\hline $\begin{array}{l}\text { Leachate composition } \\
\text { Leachate } \mathrm{pH}\end{array}$ & $\begin{array}{l}\text { Deionized water } \\
\approx 5.7\end{array}$ & $\begin{array}{l}60 / 40 \mathrm{H}_{2} \mathrm{SO}_{4} / \mathrm{HNO}_{3} \\
4.2 \text { and } 5.0\end{array}$ & $\begin{array}{l}\text { Acetic acid/acetate buffer } \\
\approx 4.9\end{array}$ \\
\hline Particle size used & $<2$ millimeters & $<2$ millimeters & $<2$ millimeters \\
\hline Sample mass & 50.0 grams & 100.0 grams & 100.0 grams \\
\hline Duration of agitation & 5 minutes & 18 hours & 18 hours \\
\hline Agitation method & Hand or mechanically shaken & End-over-end rotary & End-over-end rotary \\
\hline Filtration & Syringe & Syringe & Syringe \\
\hline Filter type & Nitrocellulose & Nitrocellulose & Nitrocellulose \\
\hline Filter pore size & 0.45 micrometer & 0.45 micrometer & 0.45 micrometer \\
\hline
\end{tabular}


also allows FLT leachate geochemical results to be directly compared to the results of the EPA 1312 (SPLP) and 1311 (TCLP) methods because all three procedures use the same leaching ratio.

- USEPA Method 1312, Synthetic Precipitation Leaching Procedure (SPLP): This procedure is a regulatory test that is also used to characterize the water soluble fraction of a sample. However, this leach test uses a long agitation period (18 hours) in order to quantify the sample constituents that would be released from samples which have been mechanically broken down by end-over-end agitation for 18 hours. Two versions of this procedure were used in this study; one using leachate adjusted to $\mathrm{pH} 4.2$ to simulate rainfall for areas east of the Mississippi River, and the other using a leachate adjusted to $\mathrm{pH} 5.0$ for simulation of rainfall in areas west of the Mississippi River.

- USEPA Method 1311, Toxicity Characteristic Leaching Procedure (TCLP): This test was designed to simulate the leaching conditions in a mixed waste municipal landfill, and is probably the most commonly used regulatory leach test. However, the primary difference between this and the leach tests described above is that this method requires the use of buffered acetic acid as the leachant. Unfortunately, the TCLP is often misused (Al-Abed and others, 2005) in geochemical studies to assess or characterize the "general" leachability of geogenic materials. Because of its reliance on acetic acid, this method fails to accurately simulate or characterize the leaching potential of materials in the "natural" environment, and thus, is likely not relevant to mine settings. The use of the TCLP leach test in this study is for comparative and illustrative purposes only.

\section{Laboratory Leaching Methods and Sample Analysis}

For all the leach studies, prepared splits of crushed and sieved $<2 \mathrm{~mm}$ material were used. The samples were leached according to the specific requirements of each leach test. After leaching, $\mathrm{pH}$ and specific conductance (SC) data were collected from unfiltered aliquots of all leachates using calibrated hand-held meters. Other portions of leachate were filtered using a $60 \mathrm{~mL}$ plastic syringe and $0.45 \mu \mathrm{m}$ pore-size, nitrocellulose capsule filters. If filtration was difficult, a 0.70 $\mu \mathrm{m}$ glass fiber pre-filter was used in series with the $0.45 \mu \mathrm{m}$ filter. Approximately $15 \mathrm{~mL}$ of each filtrate was collected in acid-washed high-density polyethylene (HDPE) bottles and preserved by acidification with two drops of ultrapure $\mathrm{HNO}_{3}$ for analysis by ICP-MS (Lamothe and others, 2002), and inductively coupled plasma-atomic emission spectrometry (ICP-AES). Another aliquot of filtrate $(40 \mathrm{~mL})$ was collected in HDPE bottles and preserved by refrigeration for determination of alkalinity and for analysis using ion chromatography (IC) (Theodorakos and others, 2002). A third sub-sample of filtrate $(30 \mathrm{~mL})$ was collected and preserved for mercury analysis using cold vapor atomic fluorescence (CVAFS) (Hageman, 2007b). This aliquot of filtrate was collected in acid-washed borosilicate glass bottles with Teflon® lined caps and preserved with $1.0 \mathrm{~mL}$ mercury-free concentrated hydrochloric acid $(\mathrm{HCl})$ and $120 \mu \mathrm{L}$ bromine chloride $(\mathrm{BrCl})$ per $30 \mathrm{~mL}$ sample.

\section{Leachate Geochemistry}

Leachate analytical results for $\mathrm{pH}$, specific conductance, ICP-MS, ICP-AES, IC, alkalinity, and mercury are presented and summarized below. Complete leachate analytical results are found in Appendix D.

\section{Leachate $\mathrm{pH}$}

Immediately following completion of the agitation period, $\mathrm{pH}$ was determined on unfiltered aliquots of all leachates using a portable Orion $\mathrm{pH}$ meter and electrode. A comparison of the unfiltered leachate $\mathrm{pH}$ values for the four mineral samples by all leach tests is presented in figure 22 . These data show that the FLT, SPLP pH 4.2, and SPLP pH 5.0 leachates all produce similar $\mathrm{pH}$ trends for the samples. Not surprisingly, TCLP $\mathrm{pH}$ values did not conform to this trend. It is obvious that these leachates were influenced by the acetic acid-based TCLP leachant because the $\mathrm{pH}$ values for all the samples hovered around the $\mathrm{pH}$ of the blank TCLP extract $(\mathrm{pH}$ 4.95). The deviation in leachate $\mathrm{pH}$ seen in the TCLP leachates once again shows a limitation of this leach test because it does not provide an accurate indication of the $\mathrm{pH}$ that would be expected to be generated from these samples in a natural setting.

When taking a closer look at the leachate $\mathrm{pH}$ trends for the samples (excluding results from the TCLP leach test), there were only minor differences observed in trends associated with the USGS FLT and the EPA SPLP tests. The FLT results showed that for a short term agitation ( 5 minutes), the azurite sample produced leachate with the highest $\mathrm{pH}(9.1)$, and data from the SPLP tests indicated that for extended (18 hours) agitation time, the bornite sample produced the highest leachate $\mathrm{pH}(9.0)$.

All three leach tests agreed that the chalcopyrite sample produced the lowest leachate $\mathrm{pH}$ of the four samples with an average $\mathrm{pH}$ of $\approx 5.5$. After averaging the leachate $\mathrm{pH}$ values for all four samples obtained using the FLT, SPLP pH 4.2, and SPLP $\mathrm{pH}$ 5.0, the following order was established for leachate $\mathrm{pH}$ : bornite $>$ azurite $>$ malachite $>$ chalcopyrite.

\section{Leachate Specific Conductance (SC)}

Post-leaching specific conductance (SC) was measured on unfiltered aliquots of leachate using a Myron L Portable 


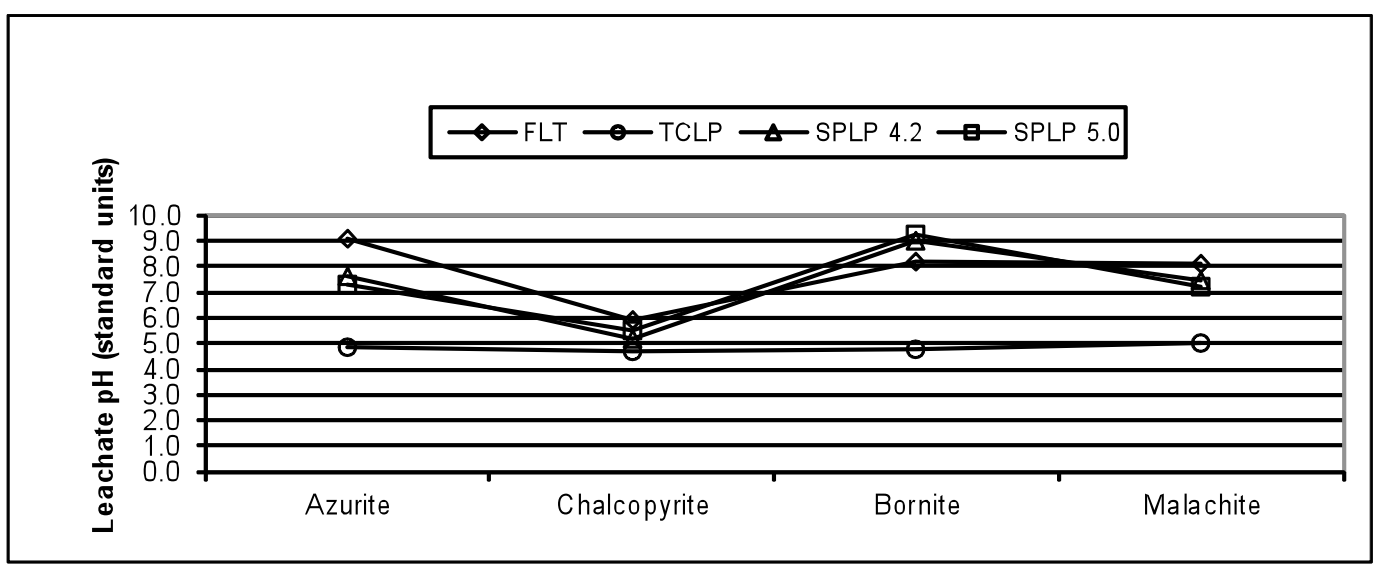

Figure 22. Leachate $\mathrm{pH}$ values for four copper minerals using the FLT, TCLP, SPLP (leachate $\mathrm{pH} 4.2$ ), and SPLP (Leachate $\mathrm{pH}$ 5.0) leaching tests.

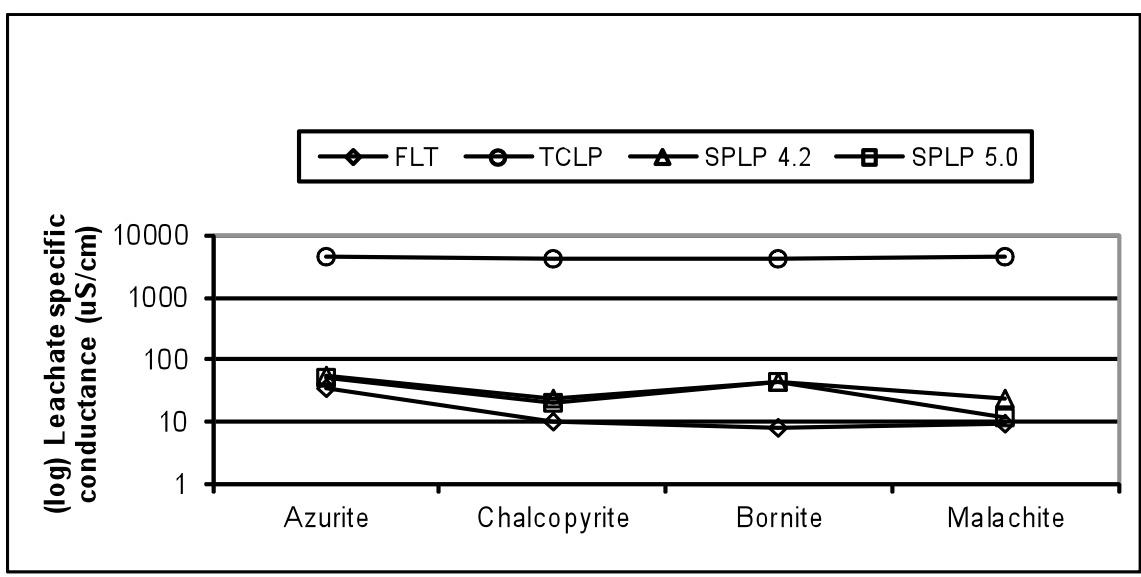

Figure 23. Leachate specific conductance (SC) values for four copper mineral samples using the FLT, TCLP, SPLP (leachate $\mathrm{pH}$ 4.2), and SPLP (Leachate $\mathrm{pH}$ 5.0) leaching tests.

Conductivity meter. Figure 23 shows leachate specific conductance results for the four mineral samples. Leachates produced using the FLT, SPLP pH 4.2, and SPLP pH 5.0 all provide similar SC trends for the samples. The 18-hour SPLP leachates produced slightly higher SC values for the chalcopyrite and especially the bornite sample when compared to the 5-minute FLT data. Overall, all four samples produced relatively low leachate SC values of $<100 \mu \mathrm{S} / \mathrm{cm}$. The SC in the TCLP leachates did not follow the same trend as the other three leach tests. Like the leachate $\mathrm{pH}$ results, it appears that the specific conductance in the TCLP leachates was controlled by the specific conductance of the pre-leach (blank) TCLP leachant $(\approx 4,100 \mu \mathrm{S} / \mathrm{cm})$. TCLP conductivity values for all four samples were more than ten times higher than those produced by the other three leach tests. These results again suggest that the TCLP leach test does not provide relevant specific conductance data in terms of accurately depicting the constituents that may be mobilized from these materials into the natural environment.

After averaging the leachate $\mathrm{SC}$ values for all four samples obtained using the FLT, SPLP pH 4.2, and SPLP pH 5.0, the azurite sample produced leachate with the highest average SC (48 $\mu \mathrm{S} / \mathrm{cm})$. The following order was established for leachate $\mathrm{SC}$ : azurite $>$ bornite $>$ chalcopyrite $>$ malachite.

\section{Major Anions by lon Chromatography}

The leachates from all four leach tests were analyzed for chloride $(\mathrm{Cl})$, fluoride $(\mathrm{F})$, and nitrate $\left(\mathrm{NO}_{3}\right)$ using IC. Analytical data for these analyses are found in table 3. Leachate geochemistry for the three water leach tests (FLT, SPLP pH 4.2, and SPLP pH 5.0) showed similar concentration trends for chloride, fluoride, and nitrate. The TCLP leach test produced much higher concentrations of fluoride and chloride.

\section{Alkalinity}

All leachates except those from the TCLP were analyzed for alkalinity. The TCLP leachates were not analyzed because of the potential for contamination of the instrumentation. Alkalinity results from these analyses are found in table 3 .

\section{Leachable Copper}

One of the primary goals of this study was to assess, quantify, and characterize the release of copper from these minerals as a result of natural leaching in the environment or movement of groundwater through copper-bearing rocks. With 
Table 3. Leachate Ion Chromatography (IC) and akalinity results for four minerals using four leach tests.

[Leaching procedures used were the USGS FLT, U.S. Geological Survey Field Leach Test; USEPA, U.S. Environmental Protection Agency; SPLP, Synthetic Precipitation Leaching Procedure, $\mathrm{pH}$ of 4.2 and 5.0; TCLP, Toxicity Characteristic Leaching Procedure; na, not analyzed]

\begin{tabular}{lccccc}
\hline Leach test & Mineral & $\mathbf{C l}$ & $\mathbf{F}$ & $\mathrm{NO}_{3}$ & $\begin{array}{c}\text { Alkalinity } \\
\mathbf{C a C O}_{3}\end{array}$ \\
\hline USGS FLT & Azurite & $(\mathrm{ppm})$ & $(\mathrm{ppm})$ & $(\mathrm{ppm})$ & $(\mathrm{ppm})$ \\
USGS FLT & Chalcopyrite & 1.6 & 0.15 & 0.40 & 6.1 \\
USGS FLT & Bornite & $<.08$ & 0.10 & 0.30 & 8.6 \\
USGS FLT & Malachite & 0.40 & 0.17 & 0.30 & 4.9 \\
& & & & & 4.1 \\
SPLP pH 4.2 & Azurite & 5.8 & 0.16 & 0.90 & 66 \\
SPLP pH 4.2 & Chalcopyrite & 1.8 & 0.08 & 0.90 & 2.5 \\
SPLP pH 4.2 & Bornite & 0.20 & 0.50 & 0.90 & 64 \\
SPLP pH 4.2 & Malachite & 1.8 & 0.30 & 0.90 & 6.7 \\
& & & & & \\
SPLP pH 5.0 & Azurite & 5.5 & 0.16 & 0.40 & 17.4 \\
SPLP pH 5.0 & Chalcopyrite & 1.8 & $<.08$ & 0.33 & 2.0 \\
SPLP pH 5.0 & Bornite & 1.3 & 0.50 & 0.40 & 10.2 \\
SPLP pH 5.0 & Malachite & 1.5 & 0.40 & 0.36 & 6.9 \\
& & & & & \\
USEPA TCLP & Azurite & 43 & 370 & $<.08$ & na \\
USEPA TCLP & Chalcopyrite & 41 & 370 & $<.08$ & na \\
USEPA TCLP & Bornite & 43 & 360 & $<.08$ & na \\
USEPA TCLP & Malachite & $<.08$ & $<.08$ & $<.08$ & na \\
\hline
\end{tabular}

this focus in mind, the mineral samples were leached using deionized water-based leachants with only slight adjustment to the leachate $\mathrm{pH}$ required in the SPLP leach tests. The aceticacid-based TCLP leach test was included in this study only to illustrate the results that may be obtained if this test is used instead of the more appropriate water-leach tests.

Figures 24-27 show comparisons of the total, or bulk, copper concentration to leached copper concentration for all four samples. To adjust the data to milligrams copper leached per kilogram of sample $(\mathrm{mg} / \mathrm{kg})$, the leachate copper concentration expressed in milligrams per liter $(\mathrm{mg} / \mathrm{L})$ was multiplied by the dilution factor (twenty). The factor of twenty is derived from the 20:1 leaching ratio required by the leach tests.

As was expected, the more easily dissolved copper carbonate minerals (azurite and malachite) released the most copper into solution. Overall, the copper leached from the samples was only a small fraction of the bulk copper concentration. Values for percent copper leached ranged from a high of 1.19 percent (azurite) to a low of 0.07 percent from the bornite sample. All of the TCLP leachates contained significantly higher (two to three orders of magnitude) copper concentration than the leachates produced using the water-based leach tests.

\section{Summary of Leaching Studies}

Several key insights were revealed as a result of the leaching studies. These findings include 1) the TCLP leaching procedure produced abnormally high concentrations of copper when compared to copper concentrations produced using the other leach tests. This finding indicates that it is not appropriate to use the TCLP to assess the general leachability of geogenic materials in a natural setting. Using the TCLP would only be appropriate if the material was going to be disposed of in a municipal landfill; 2) The simplified FLT procedure which uses a 5 minute agitation was just as effective as the long-term (18 hour agitation) leaching tests in assessing the soluble phase of the mineral samples. In fact, because of its short agitation time, the FLT results may be more indicative of the readily soluble phase of a sample that would be mobilized from materials (as run-off) when they are leached by precipitation. This is because other tests that require 18 hour agitation times tend to produce a "worst case" by mechanically breaking down the sample for 18 hours; 3 ) The FLT test that uses deionized water as the leachant produces 


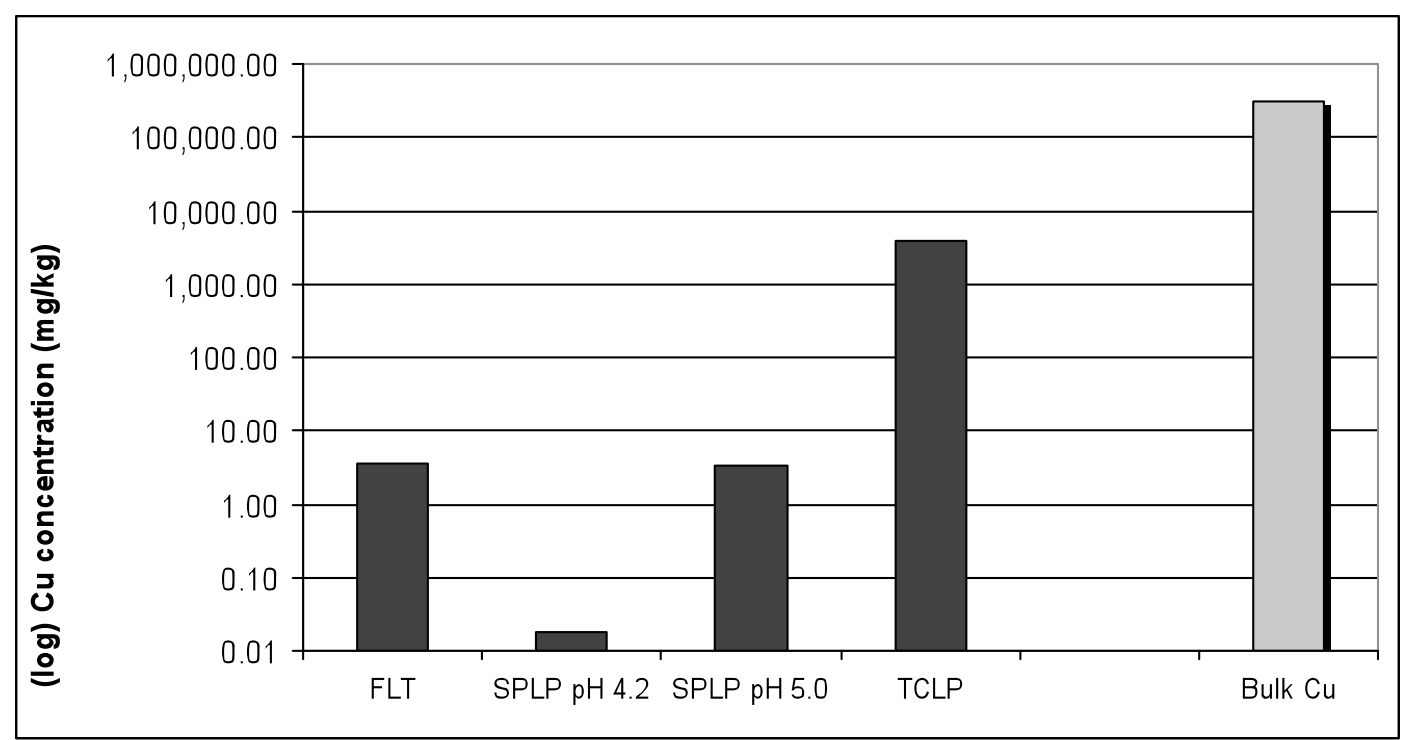

Figure 24. Azurite: Leached copper produced using four leach tests vs. bulk copper (ICP-MS).

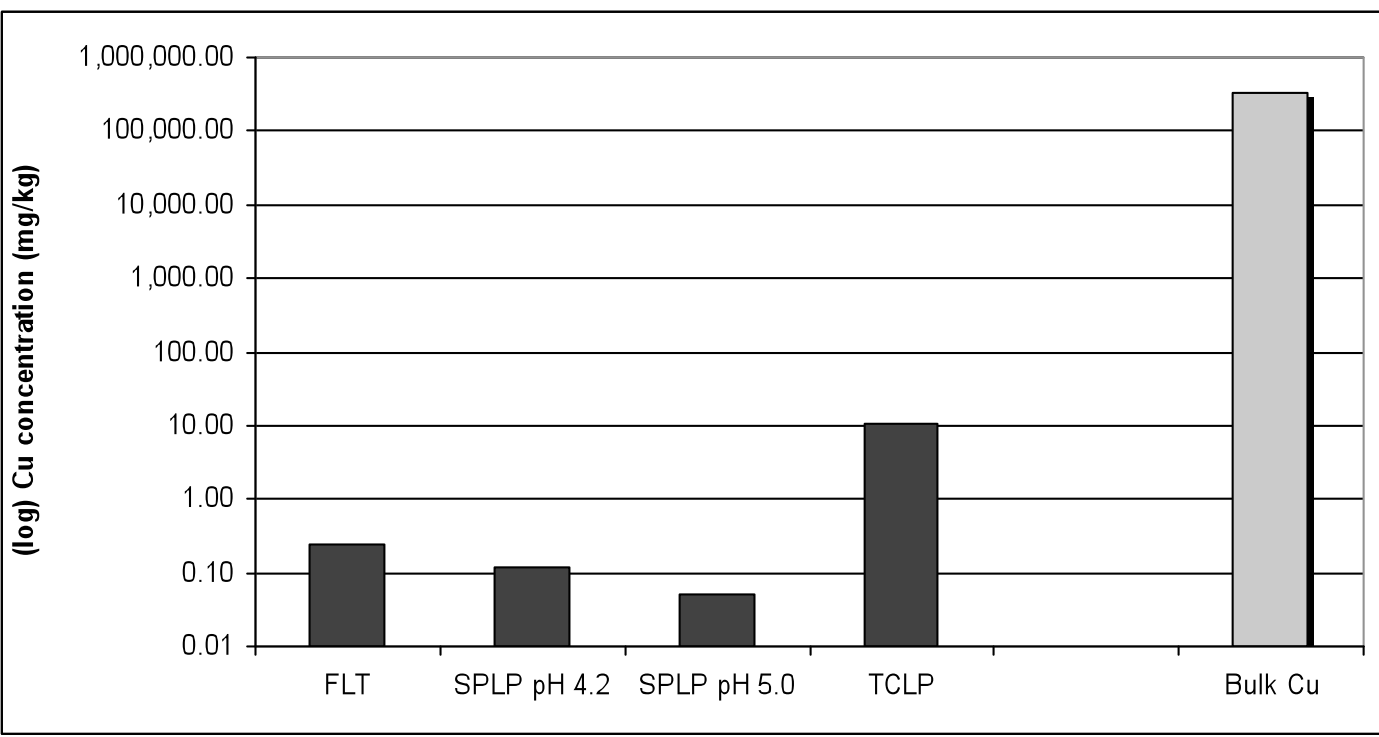

Figure 25. Chalcopyrite: leached copper produced using four leach tests vs. bulk copper.

Figure 26. Malachite:

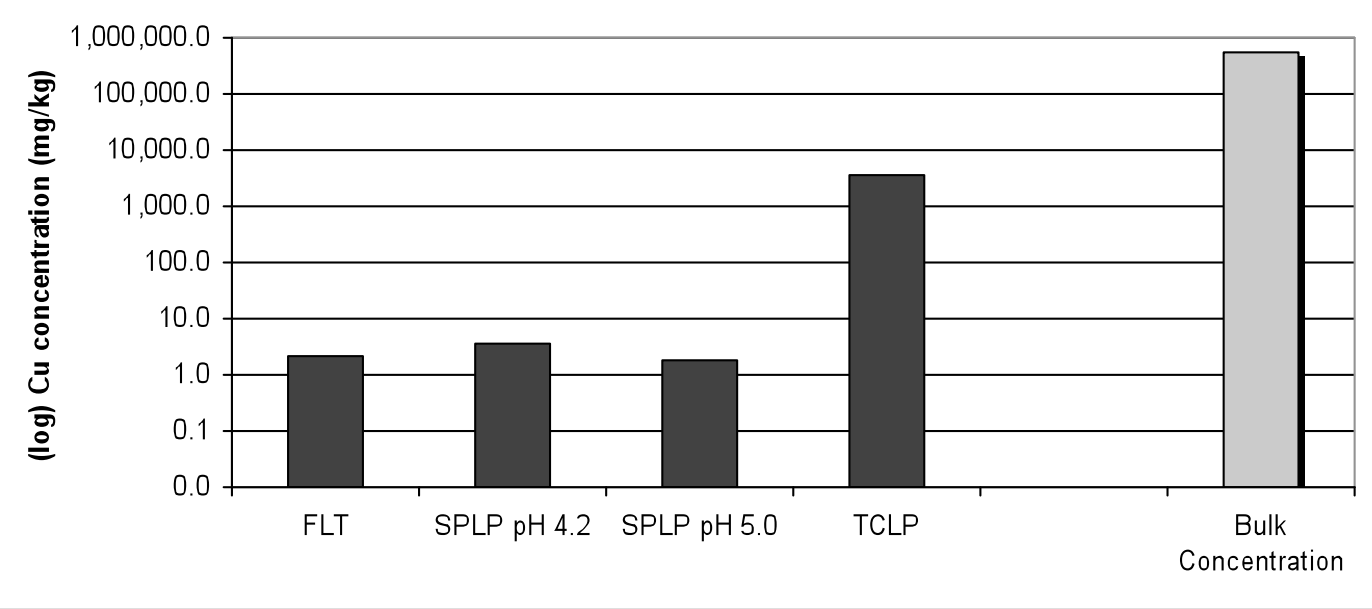
leached copper produced using four leach tests vs. bulk copper. 


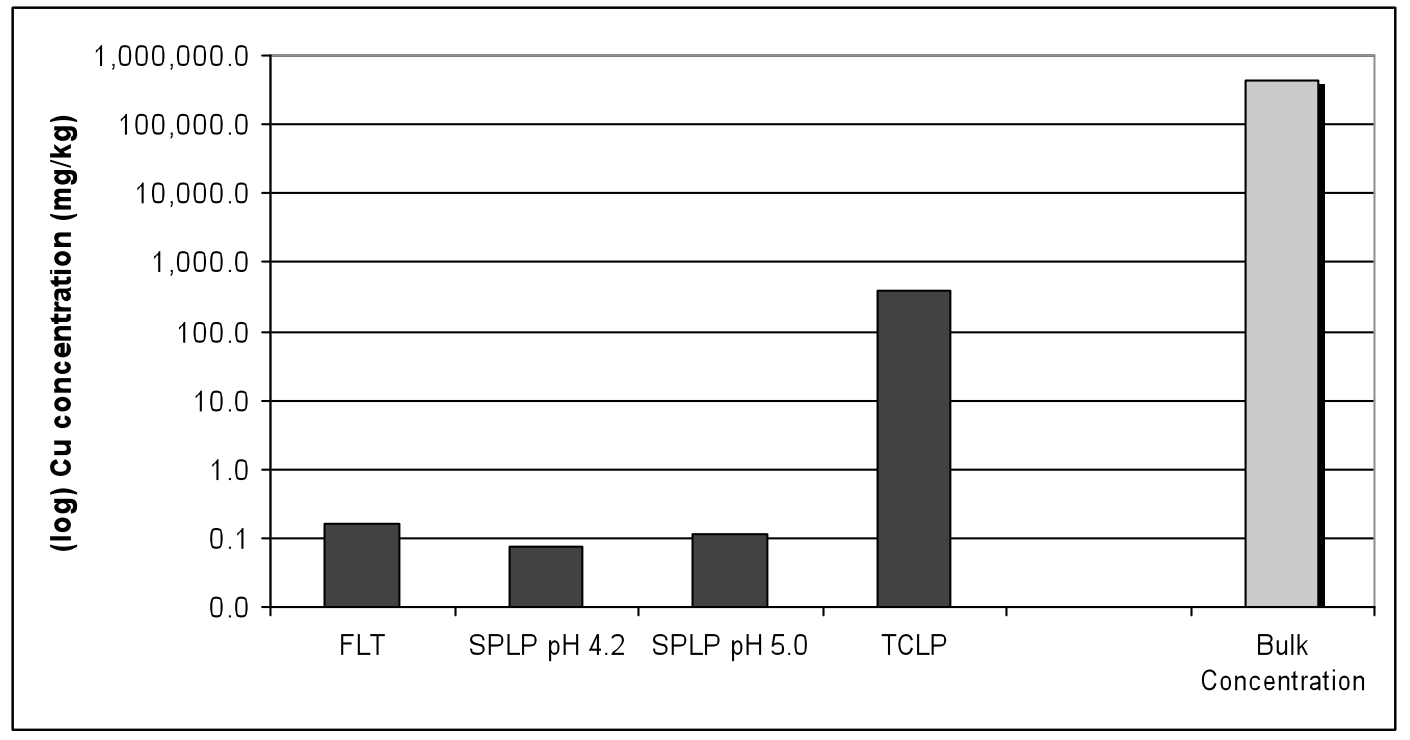

Figure 27. Bornite: Leached copper produced using four leach tests vs. bulk copper.

similar leachate geochemical trends to those produced using the slightly acidified leachants required by the EPA 1312 SPLP leach test.

\section{Acid-Base Accounting (ABA) Studies}

For this study, the net acid production (NAP) and the acid neutralizing capacity (ANC) of the minerals were determined using a modification of a method described by Lapakko and Lawrence (1993). The primary advantage of this method is that it accounts for both the acid-producing and acid-neutralizing potential of the sample using one test. The method requires digesting finely ground samples using 30 pecent hydrogen peroxide $\left(\mathrm{H}_{2} \mathrm{O}_{2}\right)$. The digestion shows that the $\mathrm{H}_{2} \mathrm{O}_{2}$ rapidly oxidizes any sulfides present in the sample thereby forming sulfuric acid $\left(\mathrm{H}_{2} \mathrm{SO}_{4}\right)$, which in turn reacts with any acid- neutralizing minerals that may be present in the sample. After these reactions are complete, the resulting digestate is filtered and titrated (if necessary) to $\mathrm{pH} 7.0$ with $0.1 \mathrm{~N}$ sodium hydroxide $(\mathrm{NaOH})$.

To carry out this procedure, $1.0 \mathrm{~g}$ of prepared sample is weighed into a 250-mL Erlenmeyer glass flask. Fifty-mL 30 percent $\mathrm{H}_{2} \mathrm{O}_{2}$ is slowly added to the sample (this procedure must be done in a hood as it often produces an exothermic reaction and the evolution of vapor). After all reaction has ceased, another 50- $\mathrm{mL} \mathrm{H}_{2} \mathrm{O}_{2}$ is added, and the flask is swirled. Again, the reaction is allowed to go to completion. The final 50- $\mathrm{mL} \mathrm{H}_{2} \mathrm{O}_{2}$ is then added and the flasks are swirled and placed on a hotplate and heated at $90{ }^{\circ} \mathrm{C}$. The samples remain on the hotplate until the reaction is complete. The flask is then removed from the hotplate and allowed to cool for 15 minutes. After cooling, 1-mL copper nitrate $\left(\mathrm{CuNO}_{3}\right)$ is added and the contents are again swirled. The flask is then placed back on the hotplate and brought to boil $\left(\approx 110^{\circ} \mathrm{C}\right)$. After 10 minutes, the flask is removed from the hotplate. When cooled to room temperature, the liquid is filtered into a clean $250-\mathrm{mL}$ glass beaker to remove the solids. As a final step, the solids retained in the filter are rinsed with $1 \mathrm{M}$ calcium chloride $\left(\mathrm{CaCl}_{2}\right)$. Following filtration, the $\mathrm{pH}$ of the filtrate is measured and recorded. If the $\mathrm{pH}$ is greater than 7.0, the sample does not have to be titrated as this indicates there is net-buffering capacity in the sample. If the $\mathrm{pH}$ is less than 7.0, the filtrate is titrated with $0.1 \mathrm{~N}$ sodium hydroxide $(\mathrm{NaOH})$. A stir bar is placed in the beaker and the liquor is constantly stirred during titration. A pH electrode is suspended in the beaker during titration and solution $\mathrm{pH}$ is constantly monitored. When the solution $\mathrm{pH}$ reaches 7.0, the quantity of $\mathrm{NaOH}$ consumed during the titration is recorded for calculation.

Upon completion of the titrations, final NAP is determined by multiplying the number of $\mathrm{ml} \mathrm{NaOH}$ consumed by the titrant concentration (0.1). The sum is then multiplied by 50. Data are reported in kilograms calcium carbonate $\left(\mathrm{CaCO}_{3}\right)$ equivalent required to neutralize 1 ton of sample $\left(\mathrm{kg} / \mathrm{t} \mathrm{CaCO}_{3}\right)$.

\section{Summary of Acid-Base Accounting Study}

After calculating the results, this procedure indicated that all four mineral samples required some $\mathrm{CaCO}_{3}$ in order to buffer the digestates. Post-calculation NAP results for all four minerals are shown in figure 28. ABA results revealed that the chalcopyrite sample required the most $\mathrm{CaCO}_{3}(142.5$ $\mathrm{kg} / \mathrm{ton}$ ) for neutralization, and thus would have the greatest propensity to produce acid. The carbonate minerals, azurite and malachite, required the least $\mathrm{CaCO}_{3}$ (both required 0.5 $\mathrm{kg} / \mathrm{ton}$ ). After ABA testing, the potential of the minerals to produce acid fell in the following order: chalcopyrite $>$ bornite $>$ azurite $=$ malachite . 


\section{Leachate $\mathrm{pH}$ as an Indicator of Acid-Base Potential}

$\mathrm{pH}$ results derived from the paste $\mathrm{pH}$ test or the FLT seem to be a reliable indicator of the "net" tendency of sample to produce or consume acid. This has been observed in other studies as well (for example, Weber and others, 2006). As explained above, prior to titration, $\mathrm{pH}$ measurements were taken on the filtrate produced from the peroxide digestion. When these data are compared to FLT leachate $\mathrm{pH}$ data, the $\mathrm{pH}$ trends are remarkably similar (fig. 29). In other studies, paste $\mathrm{pH}$ has been used for this purpose; however, the big advantage of using the FLT procedure is that the FLT produces sufficient leachate for all the desired chemical analyses, thereby allowing for the water reactivity of the sample to be fully characterized using one test. Paste $\mathrm{pH}$ tests do not produce sufficient leachate for further analysis.

Another example of the relationship between FLT leachate $\mathrm{pH}$ and the acid-base accounting results is seen when FLT leachate $\mathrm{pH}$ data are compared to the final calculated NAP results (fig. 30). In general, the samples producing the highest, most alkaline FLT leachate $\mathrm{pH}$ were also the samples that required the least $\mathrm{CaCO} 3$ after digestion with peroxide. Similarly, the samples producing the lowest, most acidic FLT leachate $\mathrm{pH}$ required the most $\mathrm{CaCO}_{3}$.

The data once again show that the 5 minute FLT is a qualitative predictor (at least for screening purposes) of which samples have the most (or least) potential to produce acid.
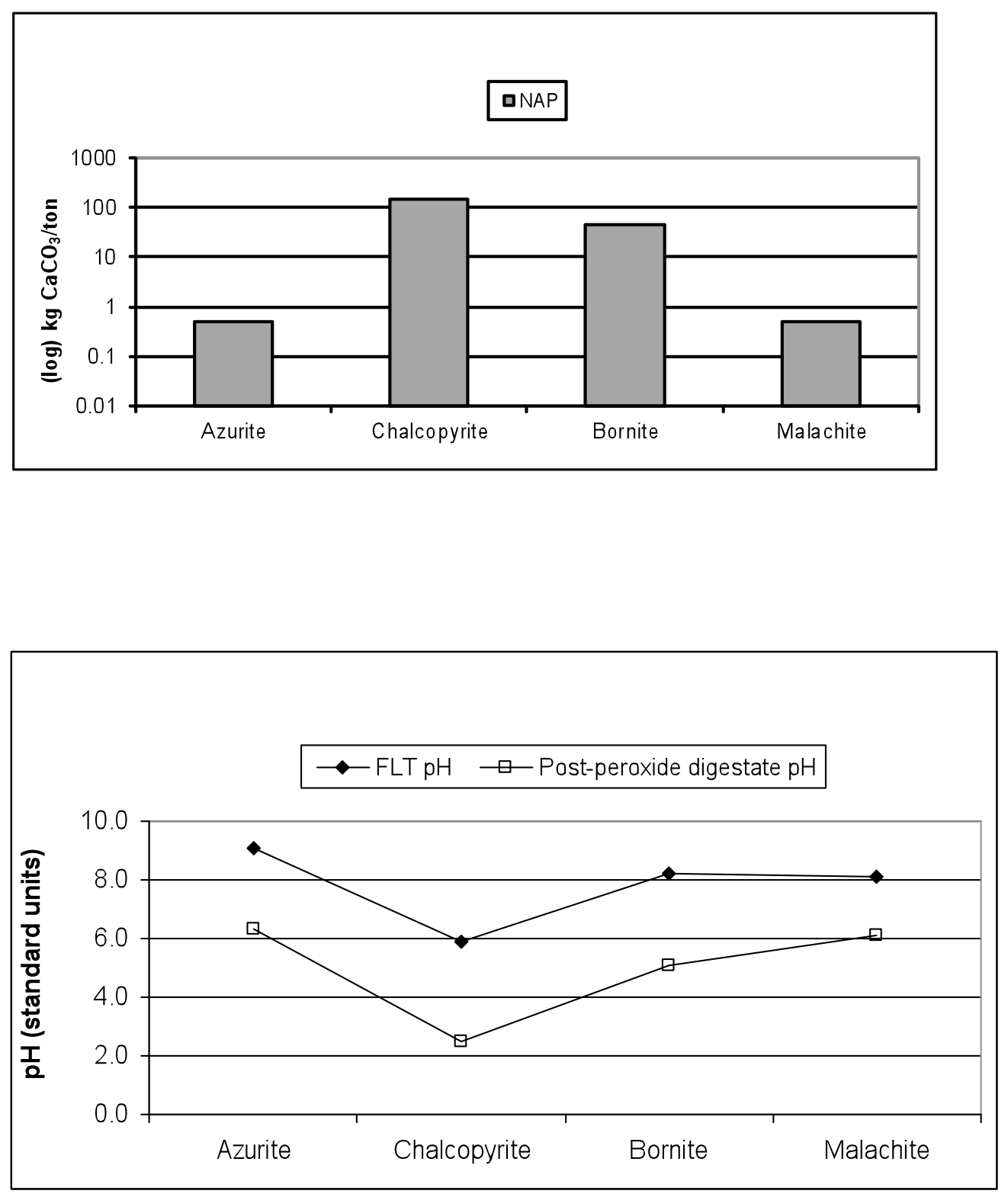

Figure 28. NAP test results for four concentrated mineral samples.

Figure 29. Water leachable $\mathrm{pH}(\mathrm{FLT})$ versus postperoxide digestate $\mathrm{pH}$ for four concentrated mineral samples. 


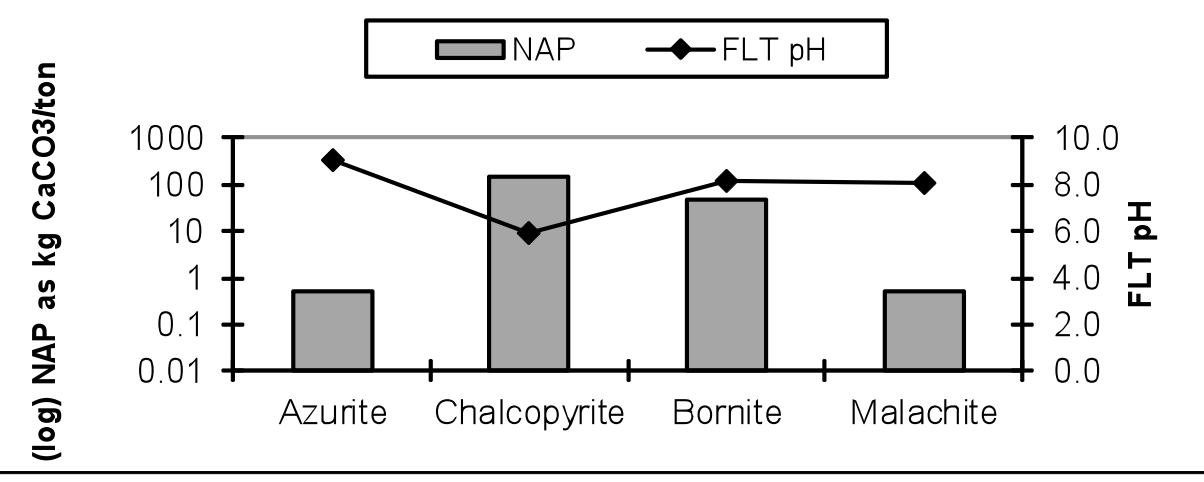

Figure 30. NAP results (log scale) versus FLT pH for four mineral samples.

\section{In Vitro Bioaccessibility Extractions}

\author{
Element Bioaccessibility, Appendix E
}

Author: Suzette Morman

\section{Introduction}

The term "bioaccessibility," the fraction of a potential toxicant in soil or other earth materials (such as volcanic ash, wildfire ash, dust) that becomes soluble in the stomach and is then available for absorption (Ruby and others, 1993), is often confused with "bioavailability," which is the amount of a potential toxicant absorbed and transported to a site of toxicological action. Generally, studies to examine bioavailability and resulting health effects or toxicity are conducted with animal surrogates or cell-line tests, both being time consuming and expensive. In Vitro bioaccessibility (IVBA) tests are inexpensive physiologically based tests designed to estimate the bioaccessibility of elements in soils, dusts, or other environmental materials by measuring the dissolution of the environmental materials in fluids compositionally similar to human body fluids (Morman and others, 2009).

For this study bioaccessibility via both ingestion- and inhalation-exposure pathways were examined, as well as bioaccessibility in a cell-carrier fluid analogous to interstitial fluid.

\section{Methods}

The samples had been previously ground, (see Driscoll, this volume). For the gastrointestinal extractions, the samples were sieved to $<250 \mu \mathrm{m}$ using a three- inch stainless steel sieve. The $<250 \mu \mathrm{m}$ size fraction is important as it is reportedly the size most likely to adhere to the hands of children and be ingested (Van Wijnen and others, 1990). For the remaining extractions, the samples were sieved to
$<20 \mu \mathrm{m}$ using a three- inch stainless-steel sieve and a Retsch A S200 auto-sieve. This fraction is an approximation of the size deemed to be respirable (generally $<5 \mu \mathrm{m}$ ). The extraction solutions were analyzed by ICP-MS for trace elements (Lamothe and others, 2002). The ICP-MS system was calibrated with multi-element standard solutions prepared from commercially available stock solutions. A procedural blank and duplicate sample was added to each sample batch for quality control purposes. All results were blank corrected prior to plotting.

\section{Ingestion Pathway}

For the ingestion pathway, most IVBA methodologies utilize either a single or sequential extraction with adjustments made to solution composition or $\mathrm{pH}$. For this study, a simple gastric extraction (Drexler and Brattin, 2007) listed as a standard operating procedure approved by the U.S. EPA (USEPA, 2008a) to measure the bioaccessibility and estimate the relative bioavailability of lead was chosen. The gastric extraction was followed by an intestinal extraction, described in Basta and others (2007) and developed by Ohio State University researchers (Ohio State University in vitro gastrointestinal method, OSU-IVG).

The simulated gastric fluid (Drexler and Brattin, 2007) is produced by adding approximately $60 \mathrm{~mL}$ concentrated $(12.1 \mathrm{~N}) \mathrm{HCl}$ to $2 \mathrm{~L}$ of $0.4 \mathrm{M}$ glycine solution $(60.06 \mathrm{~g}$ of glycine is added to $1.9 \mathrm{~L}$ of ASTM Type II deionized water). This solution is then brought to a volume of $2 \mathrm{~L}$. The solution is warmed in a water bath until it reaches $37^{\circ} \mathrm{C}$. The $\mathrm{pH}$ of the solution is adjusted to a value of $1.50 \pm 0.05$ by the drop-wise addition of concentrated $\mathrm{HCl}$. After placing the sample material (solid-to-liquid ratio of 1:100 - $1 \mathrm{~g}$ in 100 $\mathrm{mL}$ of solution) into a new acid-washed bottle, the simulated gastric fluid was added and the bottles were placed in an environmental chamber on a wrist action shaker to provide a constant temperature of $37^{\circ} \mathrm{C}$ and constant agitation. After one hour, $10 \mathrm{~mL}$ of solution was removed and filtered into a 
new acid-washed bottle using a $0.45-\mu \mathrm{m}$ nitrocellulose syringe filter. The filtered solutions were stabilized with $\mathrm{HNO}_{3}$ until analysis could be completed.

For the intestinal phase, the remaining solution was titrated to a $\mathrm{pH}$ of $5.5 \pm 0.1$ by adding saturated $\mathrm{Na}_{2} \mathrm{CO}_{3}$ followed by the addition of porcine pancreatin and porcine bile extract (Basta and others, 2007). The solutions were returned to the shaker in the environmental chamber for one hour, centrifuged, filtered through a $0.45 \mu \mathrm{m}$ nitrocellulose filter, and acidified for preservation (the OSU-IVG method uses refrigeration for preservation).

\section{Inhalation Pathway}

To model the inhalation pathway, both a lung (LSF) and phagolysosomal simulant fluid (PSF) were utilized. These simulated body fluids were developed and used to examine a variety of materials (Herting and others, 2006; Sun and others, 2001; Stefaniak and others, 2006), permit modeling of in vivo solubility, an important physiochemical factor that determines the rate and extent that particles are retained at the site of deposition, translocated to other tissues, or excreted (Ansoborlo and others, 1999; Kreyling, 1992; Kanapilly and others, 1973) relative to an inhalation pathway. The lung fluid has neutral $\mathrm{pH}$; the PSF models the lower $\mathrm{pH}$ (4.5) encountered when particles are engulfed by pulmonary alveolar macrophages, specialized lung cells involved in particle removal from the lung.

The simulated lung fluid (adapted from Mattson, 1994, and Kanapilly and others, 1973) is produced by dissolving analytical grade chemicals in ultrapure 18-ohm water. Intermediate solutions are made for ammonium chloride, sodium dihydrogen phosphate, sodium citrate, and sulfuric acid by adding each chemical to a $100 \mathrm{~mL}$ volumetric flask and filling to the mark with 18-ohm water. Our method is a batch design and differs from the flow-through design utilized by Mattson (1994), and the volume of the solutions was adjusted. The ammonium chloride solution is filtered $(0.45 \mu \mathrm{m}$ nitrocellulose filter) into a dark bottle until needed. Formaldehyde and methanol were not used in our procedure due to concerns that these chemicals could introduce excessive metal contaminants. After making the intermediate solutions, the salts and solutions are added to a one-liter flask in the following order to ensure that solids are dissolved before adding the next ingredient by the addition of 18-ohm water as needed; ammonium chloride solution, sodium chloride, sodium bicarbonate, sodium carbonate, sodium dihydrogenphosphate solution, sodium citrate solution, glycine, sulfuric acid solution, and calcium chloride solution. The flask is then filled with 18 -ohm water to the $1 \mathrm{~L}$ mark. The simulated lung fluid is warmed to $37^{\circ} \mathrm{C}$ using a preheated water bath. Finally, the $\mathrm{pH}$ of the solution is titrated to 7.4 by the drop-wise addition of $\mathrm{HCl}$. A solid to liquid ratio of 1:100 was selected based on previous studies. The solid material, previously sieved to $<20 \mu \mathrm{m}$, is placed in new acidwashed bottles to which the simulated lung fluid is added.
The bottles are placed in a preheated $\left(37^{\circ} \mathrm{C}\right)$ incubator to provide both constant rotation and temperature for 24 hours. When removed, the samples are centrifuged at 2,000 rpm for two minutes and the leachate is filtered into a new acidwashed bottle using a $0.45 \mu \mathrm{m}$ nitrocellulose syringe filter. The solutions were preserved with concentrated $\mathrm{HNO}_{3}$ until analyses could be completed.

The composition of the phagolysosomal-simulant fluid used is described by Stefaniak and others (2006). The antifungal agent aldkylbenzyldimethylammonium chloride $(\mathrm{ABDC})$ is not used in our procedure due to concerns that this chemical could introduce contaminants or alter leachate results. The $\mathrm{pH}$ of the solution was titrated to 4.5 by the addition of $0.1 \mathrm{M}$ potassium hydroxide solution. A solid-to-liquid solution ratio of 1:100 was used. The method is the same as for the lung fluid described above. The simulated lysosomal fluid is warmed to $37^{\circ} \mathrm{C}$ using a preheated water bath. The solid material, previously sieved to $<20 \mu$, was placed in new acid-washed bottles to which the simulated lysosomal fluid was added. The bottles were placed in a preheated $\left(37^{\circ} \mathrm{C}\right)$ incubator to provide both constant rotation and temperature for 24 hours. When removed, the samples were centrifuged (2,000 rpm for two minutes) and the leachate was filtered into a new acid-washed bottle using a $0.45 \mu \mathrm{m}$ nitrocellulose syringe filter. The filtered solutions were preserved with concentrated $\mathrm{HNO}_{3}$ until analysis.

\section{Cell-Carrier Fluid}

The cell-carrier fluid is a standard formula designed by Roswell Park Memorial Institute, RPMI 1640, and is generally used to culture and maintain cells. Although commercially available, the solution used in this study utilizes stock chemicals, with the addition of fetal bovine serum, and was made fresh on the day of the extraction. The method used for the extraction is identical to that of the lung and lysosomal fluid described previously.

\section{Results}

Comparison of individual elements by extraction fluid provides some generalizations as too few samples were analyzed for statistical purposes. Some elements including $\mathrm{Ag}, \mathrm{Ba}, \mathrm{Cu}$, and $\mathrm{Pb}$ were more soluble in the acidic-simulated gastric and phagolysosomal fluids than in the neutral $\mathrm{pH}$ of the lung and cell-carrier fluids. As, $\mathrm{Cd}$, and $\mathrm{U}$ were soluble in the near-neutral as well as in the acidic-simulant fluids. Table 4 presents total concentration, leachate concentration, and bioaccessibility or the percentage of the solid soluble in each leachate solution for selected trace metals that have known or suspected human or ecosystem health risk. Bioaccessibility is calculated as:

(mg leached by extraction fluid per $\mathrm{kg}$ soil)/(total concentration in soil; mg/kg) x 100 . 
Table 4. Total metal concentration, leachate concentration, and percent bioaccessibility for selected trace metals by mineral, and as measured in simulated gastric fluid (SGF), simulated intestinal fluid (SIF), simulated lung fluid (SLF), simulated phagolysosomal fluid, (SPF); and cell carrier fluid (CCF).

$[*$, indicates value was less than method detection limit, no value could be calculated because blank correction resulted in a negative number, or value was less than method detection limits. Bioaccessibility values exceeding 100 percent may result from incomplete digestion of the solid or leachate parameters; dup, duplicate sample]

\begin{tabular}{|c|c|c|c|c|c|c|}
\hline Sample & $\begin{array}{c}\text { As } \\
\text { (total, } \mathbf{m g} / \mathbf{k g} \text { ) }\end{array}$ & $\begin{array}{c}\text { As } \\
\text { (mg leached/kg solid) }\end{array}$ & $\begin{array}{c}\text { As } \\
\text { percent bioaccessible }\end{array}$ & $\begin{array}{c}\mathrm{Cd} \\
\text { (total, } \mathrm{mg} / \mathrm{kg} \text { ) }\end{array}$ & $\begin{array}{c}\text { Cd } \\
\text { (mg leached/kg solid) }\end{array}$ & $\begin{array}{c}\text { Cd } \\
\text { percent bioaccessible }\end{array}$ \\
\hline Azurite SGF & 48 & 22 & 46 & 0.02 & $*$ & $*$ \\
\hline dup Azurite SGF & 48 & 21 & 43 & 0.02 & $*$ & $*$ \\
\hline Bornite SGF & 14 & * & * & 416 & 1 & 0.3 \\
\hline Chalcopyrite SGF & 300 & 2 & 1 & 15 & 0.9 & 6 \\
\hline Malachite SGF & 5 & $*$ & $*$ & 0.28 & 0.03 & 11 \\
\hline Azurite SIF & 48 & 23 & 48 & 0.02 & 0.03 & 140 \\
\hline dup Azurite SIF & 48 & 23 & 47 & 0.02 & * & * \\
\hline Bornite SIF & 14 & 1 & 8 & 416 & 1 & 0.3 \\
\hline Chalcopyrite SIF & 300 & 2 & 1 & 15 & 0.8 & 5 \\
\hline Malachite SIF & 5 & * & * & 0.28 & 0.01 & 4 \\
\hline Azurite SLF & 48 & 7 & 14 & 0.02 & $*$ & $*$ \\
\hline Bornite SLF & 14 & $*$ & & 416 & 2 & 0.4 \\
\hline Chalcopyrite SLF & 300 & 3 & 1 & 15 & 0.5 & 3 \\
\hline Malachite SLF & 5 & $*$ & $*$ & 0.28 & $*$ & * \\
\hline Azurite SPF & 48 & 8 & 17 & 0.02 & 0.01 & 60 \\
\hline Bornite SPF & 14 & 0.7 & 5 & 416 & 4 & 1 \\
\hline dup Bornite SPF & 14 & 0.6 & 4 & 416 & 4 & 1 \\
\hline Chalcopyrite SPF & 300 & 3 & 1 & 15 & 2 & 16 \\
\hline Malachite SPF & 5 & 0.6 & 12 & 0.28 & 0.02 & 5 \\
\hline Azurite CCF & 48 & 5 & 11 & 0.02 & * & * \\
\hline Bornite CCF & 14 & 0.2 & 1 & 416 & 3 & 1 \\
\hline Chalcopyrite CCF & 300 & 3 & 1 & 15 & 1 & 9 \\
\hline Malachite CCF & 5 & 0.3 & 7 & 0.28 & * & * \\
\hline dup Malachite CCF & 5 & 0.4 & 7 & 0.28 & $*$ & $*$ \\
\hline
\end{tabular}


Table 4. Total metal concentration, leachate concentration, and percent bioaccessibility for selected trace metals by mineral, and as measured in simulated gastric fluid (SGF), simulated intestinal fluid (SIF), simulated lung fluid (SLF), simulated phagolysosomal fluid, (SPF); and cell carrier fluid (CCF).—Continued

[*, indicates value was less than method detection limit, no value could be calculated because blank correction resulted in a negative number, or value was less than method detection limits. Bioaccessibility values exceeding 100 percent may result from incomplete digestion of the solid or leachate parameters; dup, duplicate sample]

\begin{tabular}{|c|c|c|c|c|c|c|}
\hline & $\begin{array}{c}\mathrm{Cu} \\
\text { (total, } \mathrm{mg} / \mathrm{kg} \text { ) }\end{array}$ & $\begin{array}{c}\mathrm{Cu} \\
\text { (mg leached/kg solid) }\end{array}$ & $\begin{array}{c}\mathrm{Cu} \\
\text { percent bioaccessible }\end{array}$ & $\begin{array}{c}\mathrm{Ni} \\
\text { (total, } \mathrm{mg} / \mathrm{kg} \text { ) }\end{array}$ & $\begin{array}{c}\mathrm{Ni} \\
\text { (mg leached/kg solid) }\end{array}$ & $\begin{array}{c}\mathrm{Ni} \\
\text { percent bioaccessible }\end{array}$ \\
\hline Azurite SGF & 305000 & 221999 & 73 & 7 & 0.7 & 10 \\
\hline dup Azurite SGF & 305000 & 217999 & 71 & 7 & 0.6 & 9 \\
\hline Bornite SGF & 430000 & 8459 & 2 & 6 & 6 & 112 \\
\hline Chalcopyrite SGF & 321000 & 549 & 0.2 & 71 & 1 & 2 \\
\hline Malachite SGF & 534000 & 350000 & 66 & 6530 & 2270 & 35 \\
\hline Azurite SIF & 305000 & 208000 & 68 & 7 & 0.7 & 11 \\
\hline dup Azurite SIF & 305000 & 211000 & 69 & 7 & 0.7 & 10 \\
\hline Bornite SIF & 430000 & 7970 & 2 & 6 & 6 & 104 \\
\hline Chalcopyrite SIF & 321000 & 460 & 0.1 & 71 & 1 & 2 \\
\hline Malachite SIF & 534000 & 309000 & 58 & 6530 & 2190 & 34 \\
\hline Azurite SLF & 305000 & 14600 & 5 & 7 & * & * \\
\hline Bornite SLF & 430000 & 4380 & 1 & 6 & 6 & 100 \\
\hline Chalcopyrite SLF & 321000 & 837 & 0.3 & 71 & 2 & 3 \\
\hline Malachite SLF & 534000 & 13300 & 2 & 6530 & 76 & 1 \\
\hline Azurite SPF & 305000 & 36800 & 12 & 7 & 0.7 & 10 \\
\hline Bornite SPF & 430000 & 4310 & 1 & 6 & 12 & 208 \\
\hline dup Bornite SPF & 430000 & 4580 & 1 & 6 & 13 & 228 \\
\hline Chalcopyrite SPF & 321000 & 441 & 0.1 & 71 & 3 & 4 \\
\hline Malachite SPF & 534000 & 37000 & 7 & 6530 & 258 & 4 \\
\hline Azurite CCF & 305000 & 6808 & 2 & 7 & 0.3 & 5 \\
\hline Bornite CCF & 430000 & 1728 & 0.4 & 6 & 4 & 72 \\
\hline Chalcopyrite CCF & 321000 & 363 & 0.1 & 71 & 2 & 3 \\
\hline Malachite CCF & 534000 & 6008 & 1 & 6530 & 62 & 1 \\
\hline dup Malachite CCF & 534000 & 6168 & 1 & 6530 & 64 & 1 \\
\hline
\end{tabular}


Table 4. Total metal concentration, leachate concentration, and percent bioaccessibility for selected trace metals by mineral, and as measured in simulated gastric

fluid (SGF), simulated intestinal fluid (SIF), simulated lung fluid (SLF), simulated phagolysosomal fluid, (SPF); and cell carrier fluid (CCF).—Continued

${ }^{*}$, indicates value was less than method detection limit, no value could be calculated because blank correction resulted in a negative number, or value was less than method detection limits. Bioaccessibility values exceeding 100 percent may result from incomplete digestion of the solid or leachate parameters; dup, duplicate sample]

\begin{tabular}{|c|c|c|c|c|c|c|}
\hline & $\begin{array}{c}\mathrm{Pb} \\
\text { (total, } \mathrm{mg} / \mathrm{kg} \text { ) }\end{array}$ & $\begin{array}{c}\mathrm{Pb} \\
\text { (mg leached/kg solid) }\end{array}$ & $\begin{array}{c}\mathrm{Pb} \\
\text { percent bioaccessible }\end{array}$ & $\begin{array}{c}\mathrm{U} \\
\text { (total, } \mathrm{mg} / \mathrm{kg} \text { ) }\end{array}$ & $\begin{array}{c}\mathrm{U} \\
\text { (mg leached/kg solid) }\end{array}$ & $\begin{array}{c}\mathrm{U} \\
\text { percent bioaccessible }\end{array}$ \\
\hline Azurite SGF & 30 & 3 & 11 & 4 & 0.4 & 8 \\
\hline dup Azurite SGF & 30 & 4 & 12 & 4 & 0.3 & 8 \\
\hline Bornite SGF & 9830 & 189 & 2 & 11 & 0.8 & 7 \\
\hline Chalcopyrite SGF & 442 & 74 & 17 & 0.4 & $*$ & $*$ \\
\hline Malachite SGF & 315 & 179 & 57 & 374 & 265 & 71 \\
\hline Azurite SIF & 30 & 0.3 & 1 & 4 & $*$ & * \\
\hline dup Azurite SIF & 30 & 0.3 & 1 & 4 & * & * \\
\hline Bornite SIF & 9830 & 66 & 1 & 11 & $*$ & $*$ \\
\hline Chalcopyrite SIF & 442 & 31 & 7 & 0.4 & $*$ & $*$ \\
\hline Malachite SIF & 315 & 10 & 3 & 374 & 5 & 1 \\
\hline Azurite SLF & 30 & $*$ & $*$ & 4 & 0.3 & 6 \\
\hline Bornite SLF & 9830 & 94 & 1 & 11 & 0.7 & 7 \\
\hline Chalcopyrite SLF & 442 & 8 & 2 & 0.4 & 0.2 & 43 \\
\hline Malachite SLF & 315 & * & $*$ & 374 & 49 & 13 \\
\hline Azurite SPF & 30 & 3 & 11 & 4 & 0.2 & 3 \\
\hline Bornite SPF & 9830 & 544 & 6 & 11 & 0.7 & 6 \\
\hline dup Bornite SPF & 9830 & 567 & 6 & 11 & 0.7 & 6 \\
\hline Chalcopyrite SPF & 442 & 84 & 19 & 0.4 & 0.1 & 25 \\
\hline Malachite SPF & 315 & 10 & 3 & 374 & 47 & 13 \\
\hline Azurite CCF & 30 & 0.2 & 1 & 4 & 0.1 & 3 \\
\hline Bornite CCF & 9830 & 53 & 1 & 11 & 0.5 & 5 \\
\hline Chalcopyrite $\mathrm{CCF}$ & 442 & 2 & 1 & 0.4 & 0.1 & 24 \\
\hline Malachite CCF & 315 & 0.7 & 0 & 374 & 19 & 5 \\
\hline dup Malachite CCF & 315 & 0.5 & 0 & 374 & 18 & 5 \\
\hline
\end{tabular}


Table 4. Total metal concentration, leachate concentration, and percent bioaccessibility for selected trace metals by mineral, and as measured in simulated gastric fluid (SGF), simulated intestinal fluid (SIF), simulated lung fluid (SLF), simulated phagolysosomal fluid, (SPF); and cell carrier fluid (CCF)._-Continued

$[*$, indicates value was less than method detection limit, no value could be calculated because blank correction resulted in a negative number, or value was less than method detection limits. Bioaccessibility values exceeding 100 percent may result from incomplete digestion of the solid or leachate parameters; dup, duplicate sample]

\begin{tabular}{|c|c|c|c|c|c|c|}
\hline & $\begin{array}{c}\mathrm{V} \\
\text { (total, } \mathrm{mg} / \mathrm{kg} \text { ) }\end{array}$ & $\begin{array}{c}\mathrm{V} \\
\text { (mg leached/kg solid) }\end{array}$ & $\begin{array}{c}\mathrm{V} \\
\text { percent bioaccessible }\end{array}$ & $\begin{array}{c}\mathrm{Zn} \\
\text { (total, } \mathrm{mg} / \mathrm{kg} \text { ) }\end{array}$ & $\begin{array}{l}\mathrm{Zn} \text { (mg } \\
\text { leached/kg solid) }\end{array}$ & $\begin{array}{c}\mathrm{Zn} \\
\text { percent bioaccessible }\end{array}$ \\
\hline Azurite SGF & 45 & 0.7 & 1 & 32 & $*$ & $*$ \\
\hline dup Azurite SGF & 45 & 0.6 & 1 & 32 & * & * \\
\hline Bornite SGF & 34 & 2 & 6 & 45900 & 110 & 0.2 \\
\hline Chalcopyrite SGF & 1 & 0.1 & 5 & 934 & 24 & 3 \\
\hline Malachite SGF & 9 & * & $*$ & 41 & 4 & 9 \\
\hline Azurite SIF & 45 & 0.2 & 0.5 & 32 & * & * \\
\hline dup Azurite SIF & 45 & 0.1 & 0.1 & 32 & * & * \\
\hline Bornite SIF & 34 & 2 & 6 & 45900 & 82 & 0.2 \\
\hline Chalcopyrite SIF & 1 & * & * & 934 & 18 & 2 \\
\hline Malachite SIF & 9 & $*$ & $*$ & 41 & $*$ & $*$ \\
\hline Azurite SLF & 45 & 1 & 3 & 32 & 5 & 16 \\
\hline Bornite SLF & 34 & 0.7 & 2 & 45900 & 162 & 0.4 \\
\hline Chalcopyrite SLF & 1 & * & * & 934 & 20 & 2 \\
\hline Malachite SLF & 9 & $*$ & $*$ & 41 & * & * \\
\hline Azurite SPF & 45 & 0.7 & 1 & 32 & 2 & 6 \\
\hline Bornite SPF & 34 & 0.9 & 3 & 45900 & 348 & 1 \\
\hline dup Bornite SPF & 34 & 1.0 & 3 & 45900 & 359 & 1 \\
\hline Chalcopyrite SPF & 1 & 0.2 & 12 & 934 & 173 & 19 \\
\hline Malachite SPF & 9 & 0.1 & 1 & 41 & 1 & 2 \\
\hline Azurite $\mathrm{CCF}$ & 45 & 0.6 & 1 & 32 & * & * \\
\hline Bornite CCF & 34 & 0.3 & 1 & 45900 & 192 & 0.4 \\
\hline Chalcopyrite CCF & 1 & $*$ & $*$ & 934 & 39 & 4 \\
\hline Malachite CCF & 9 & 0.04 & 0.4 & 41 & * & * \\
\hline dup Malachite CCF & 9 & 0.1 & 1 & 41 & * & * \\
\hline
\end{tabular}


Blank correction prior to calculations occasionally resulted in a negative number and bioaccessibility was not determined. Leached concentrations for several samples were less than the level of quantification and were not reported in table 4 or Appendix E. Bioaccessibility values exceeding 100 percent may result from analytical error. Factors that may introduce analytical error include incomplete digestion of the solid, sample heterogeneity, and solid-to-solution ratio.

The four samples contained total copper concentrations that ranged from $305,000 \mathrm{mg} / \mathrm{kg}$ (azurite) to $534,000 \mathrm{mg} /$ $\mathrm{kg}$ (malachite). Except for the azurite and malachite SGF and SIF leachates ( $>58$ percent), copper bioaccessibility was low in all leachates $(<10$ percent). Given the total concentrations however, this amounts to elevated concentrations in solution. Figures 31-34 show the bioaccessibility of copper by mineral and leachate type. The two copper carbonate minerals, azurite and malachite, demonstrate greater bioaccessibility despite similar total concentration than the two sulfide minerals (bornite and chalcopyrite). As previously stated, copper concentrations in the acidic SGF are greater than in the high $\mathrm{pH}$ solutions, but once in solution it remained so in the higher $\mathrm{pH}$ sequential-intestinal extraction unlike $\mathrm{Pb}$ and some other metals. The two sulfide minerals display very low copper bioaccessibility in all leachate solutions, less than 2 percent for bornite and less than 0.4 percent for chalcopyrite.
Similarly, arsenic bioaccessibility is significantly higher in azurite than chalcopyrite (figs. 35-36).

\section{Discussion}

The samples chosen for this study included four copperbearing minerals. Copper is an essential element at low concentrations. Most copper exposures are related to industrial or accidental/intentional ingestion but drinking-water concentrations greater than $3 \mathrm{mg} \mathrm{Cu} / \mathrm{L}$ are sufficient to produce gastrointestinal symptoms (Pizarro and others, 1999). For monomineralic samples, such as those examined here, no similar studies to determine bioaccessibility were discovered for comparison.

Most studies have examined bioaccessibility of minerals in mine waste (Ruby and others, 1993, 1996; Schaider and others, 2007) or soils affected by smelters (Karczewska, 1996; Carrizales and others, 2006). Many studies have focused on element mobility and controls on bioaccessibility such as particle size, soil $\mathrm{pH}$, the amount of organic carbon present, the presence of clays, and iron $(\mathrm{Fe})$ or manganese $(\mathrm{Mn})$ oxides. Lacking those controls, this study focused on mineral solubility in fluids of a similar $\mathrm{pH}$ and composition to those of body fluids. For these samples it is evident that mineral form and solution $\mathrm{pH}$ are primary controls of bioaccessibility. Mineral phase is an important determinant of $\mathrm{Pb}$ and As bioaccessibility as discussed in Ruby and others (1999).

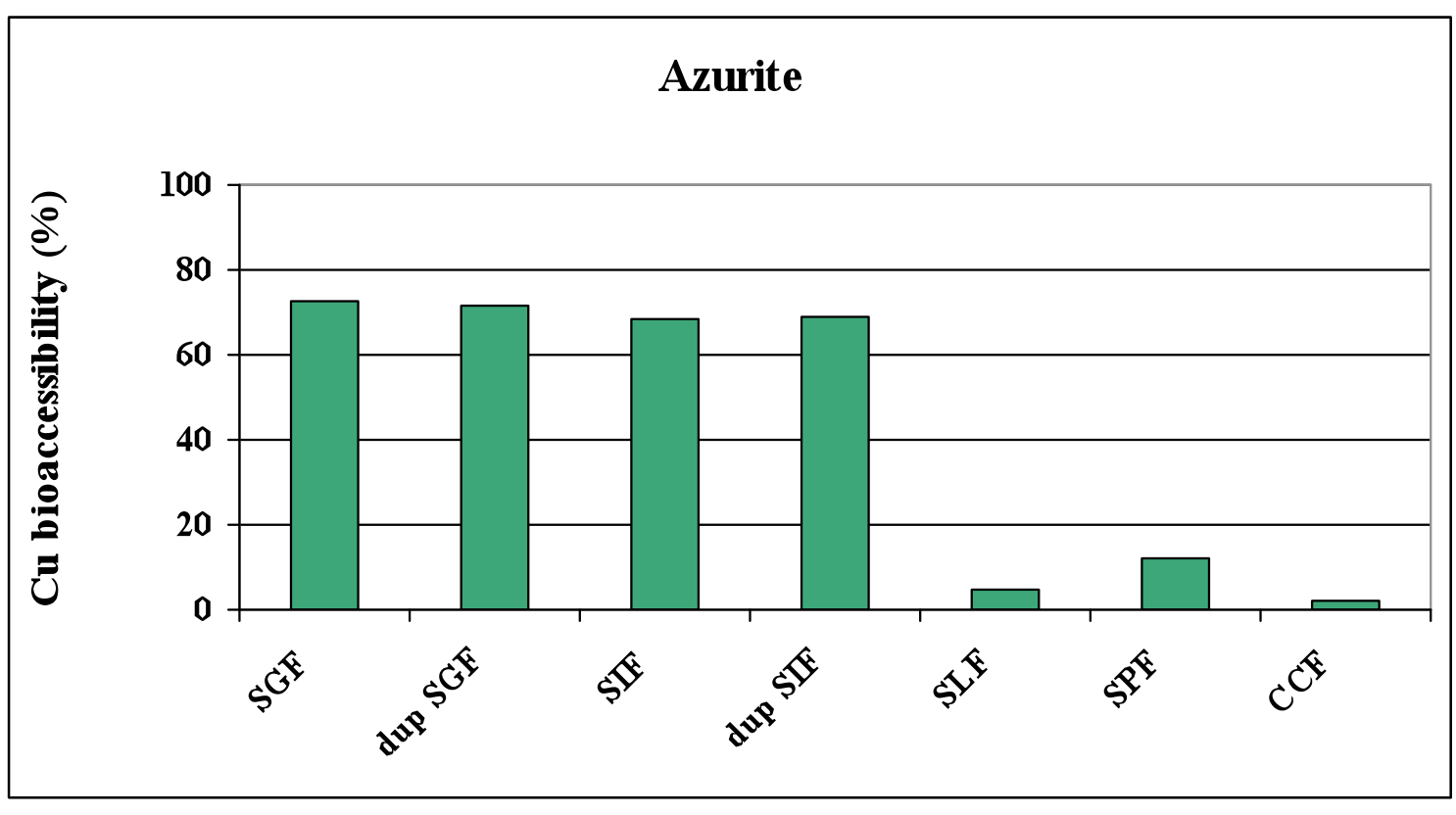

Figure 31. Bioaccessibility of copper in azurite, measured in simulated gastric fluid (SGF), intestinal fluid (SIF), lung fluid (SLF), phagolysosomal fluid (PSF) and cell carrier fluid (CCF) and presented as the per cent of the solid soluble in the fluid. 


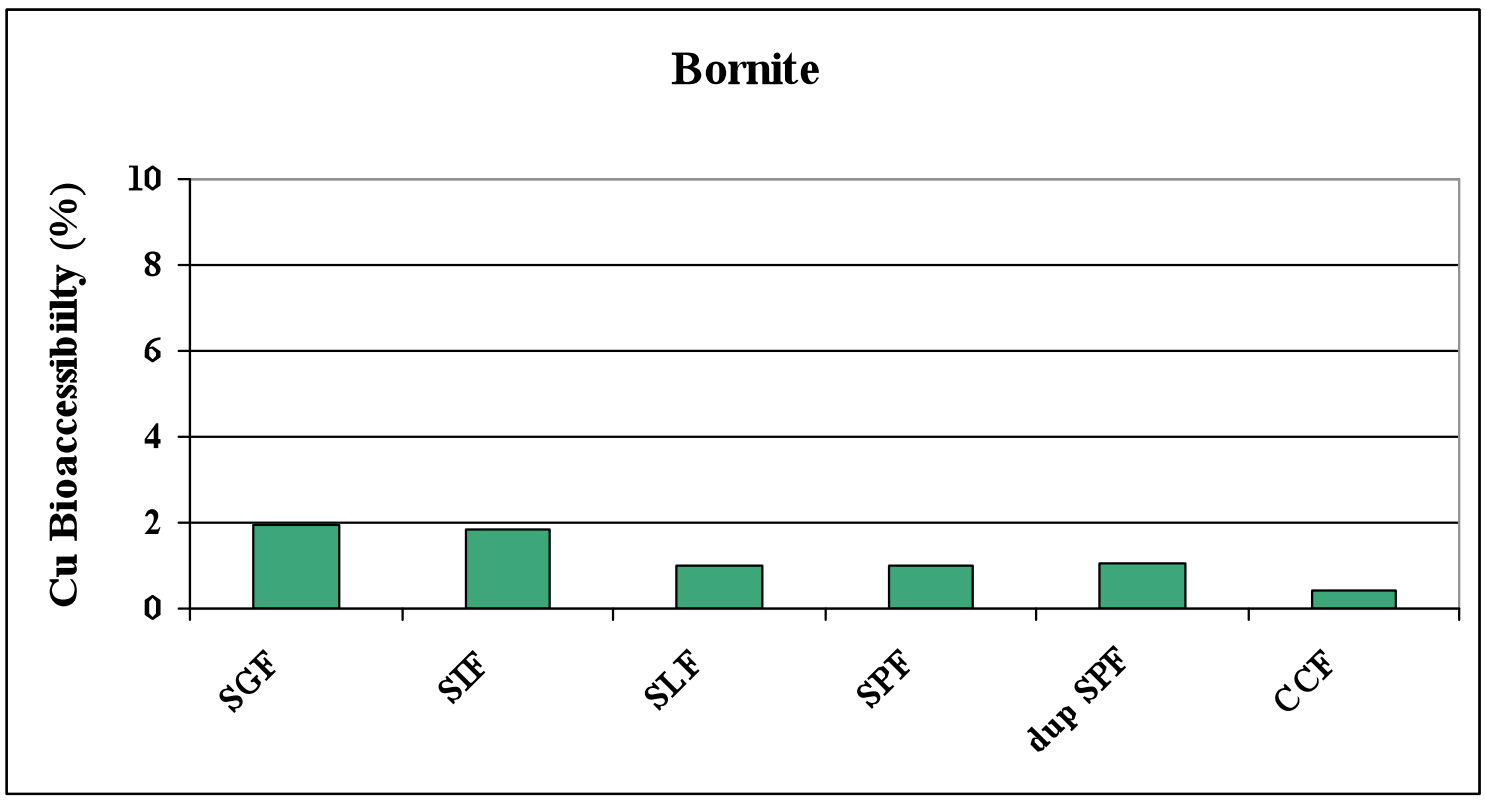

Figure 32. Bioaccessibility of copper in bornite, measured in simulated gastric fluid (SGF), intestinal fluid (SIF), lung fluid (SLF), phagolysosomal fluid (PSF) and cell carrier fluid (CCF) and presented as the per cent of the solid soluble in the fluid.

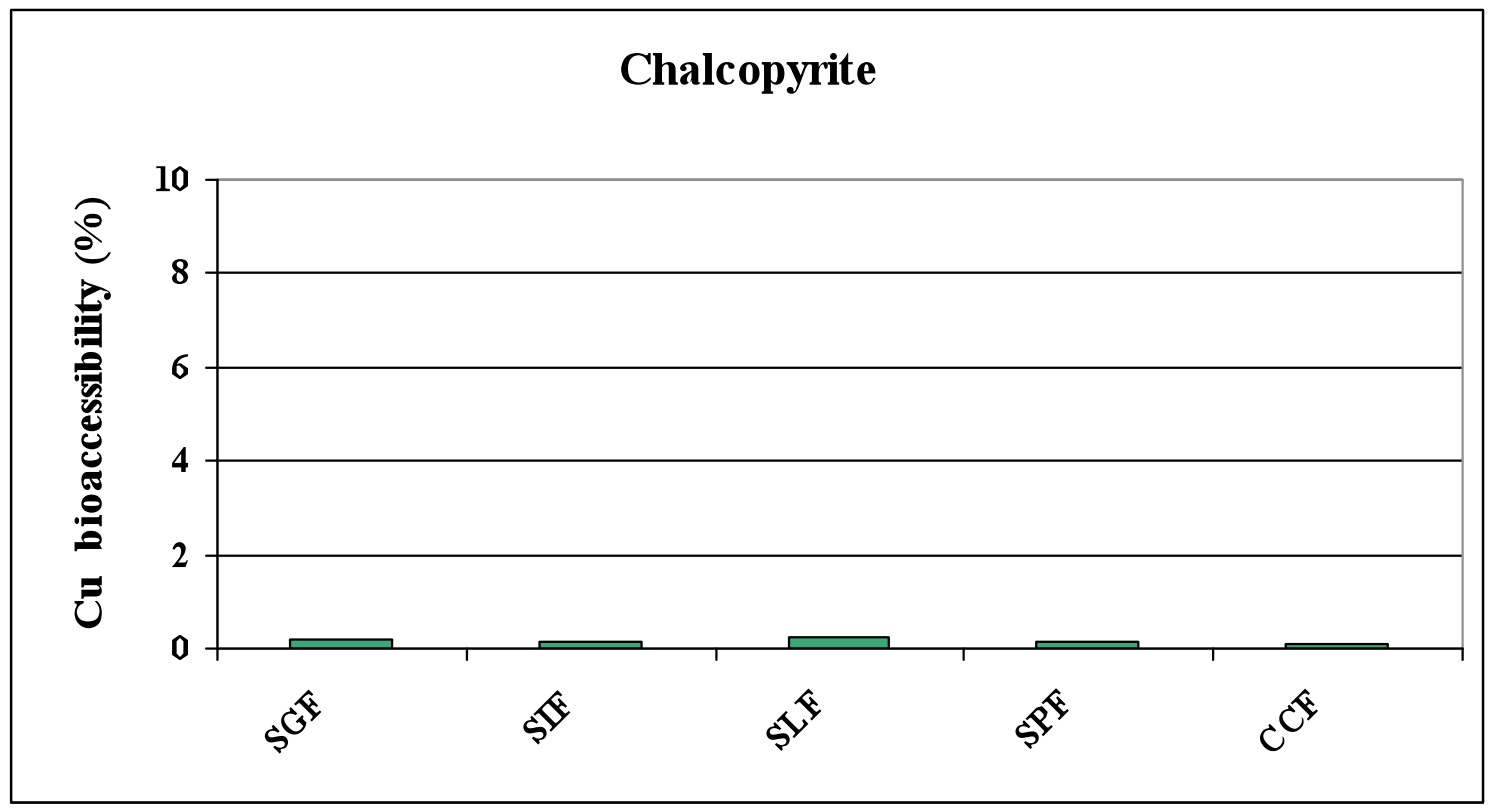

Figure 33. Bioaccessibility of copper in chalcopyrite, measured in simulated gastric fluid (SGF), intestinal fluid (SIF), lung fluid (SLF), phagolysosomal fluid (PSF) and cell carrier fluid (CCF) and presented as the per cent of the solid soluble in the fluid. 


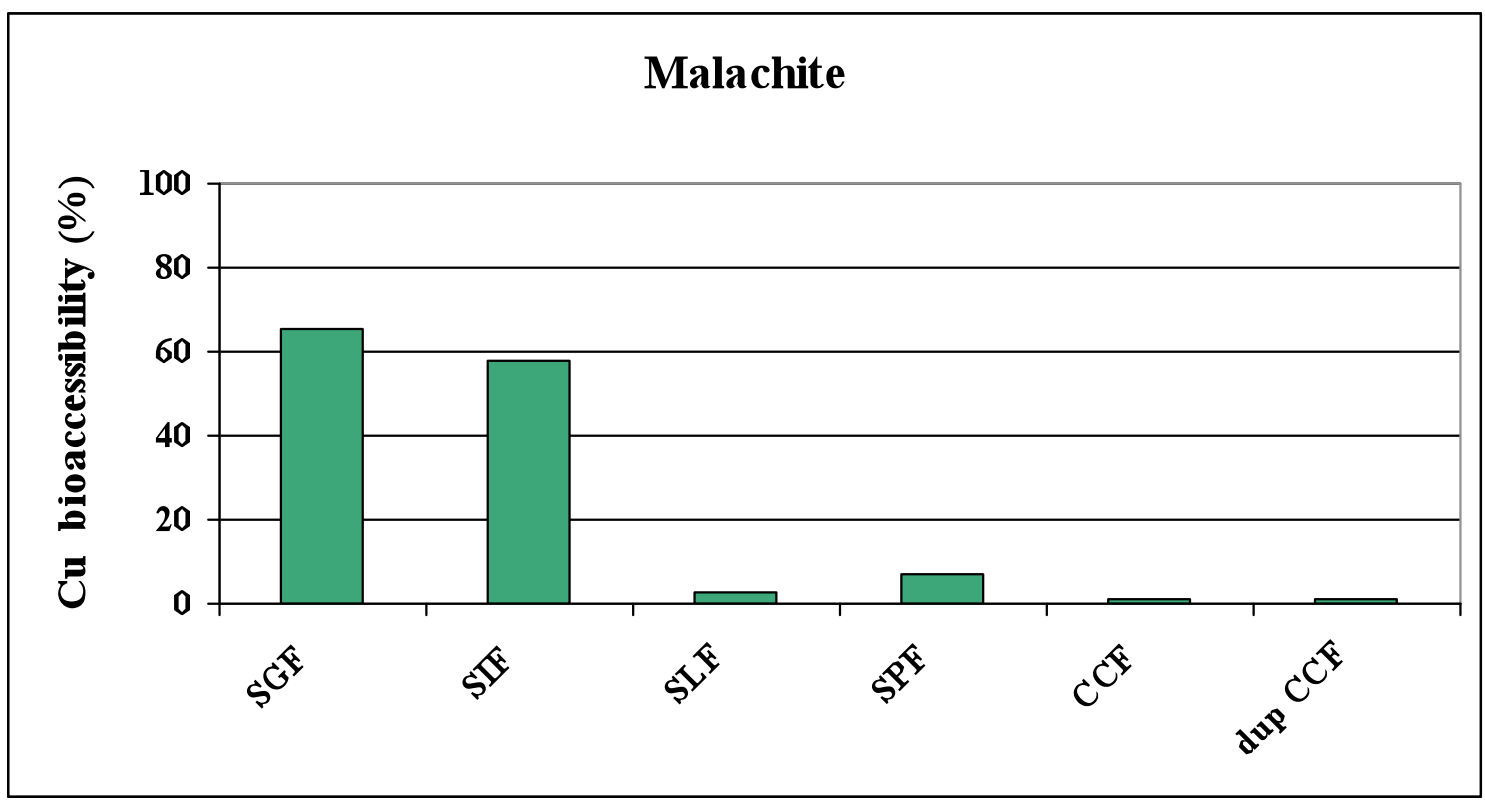

Figure 34. Bioaccessibility of copper in malachite, measured in simulated gastric fluid (SGF), intestinal fluid (SIF), lung fluid (SLF), phagolysosomal fluid (PSF) and cell carrier fluid (CCF) and presented as the per cent of the solid soluble in the fluid.

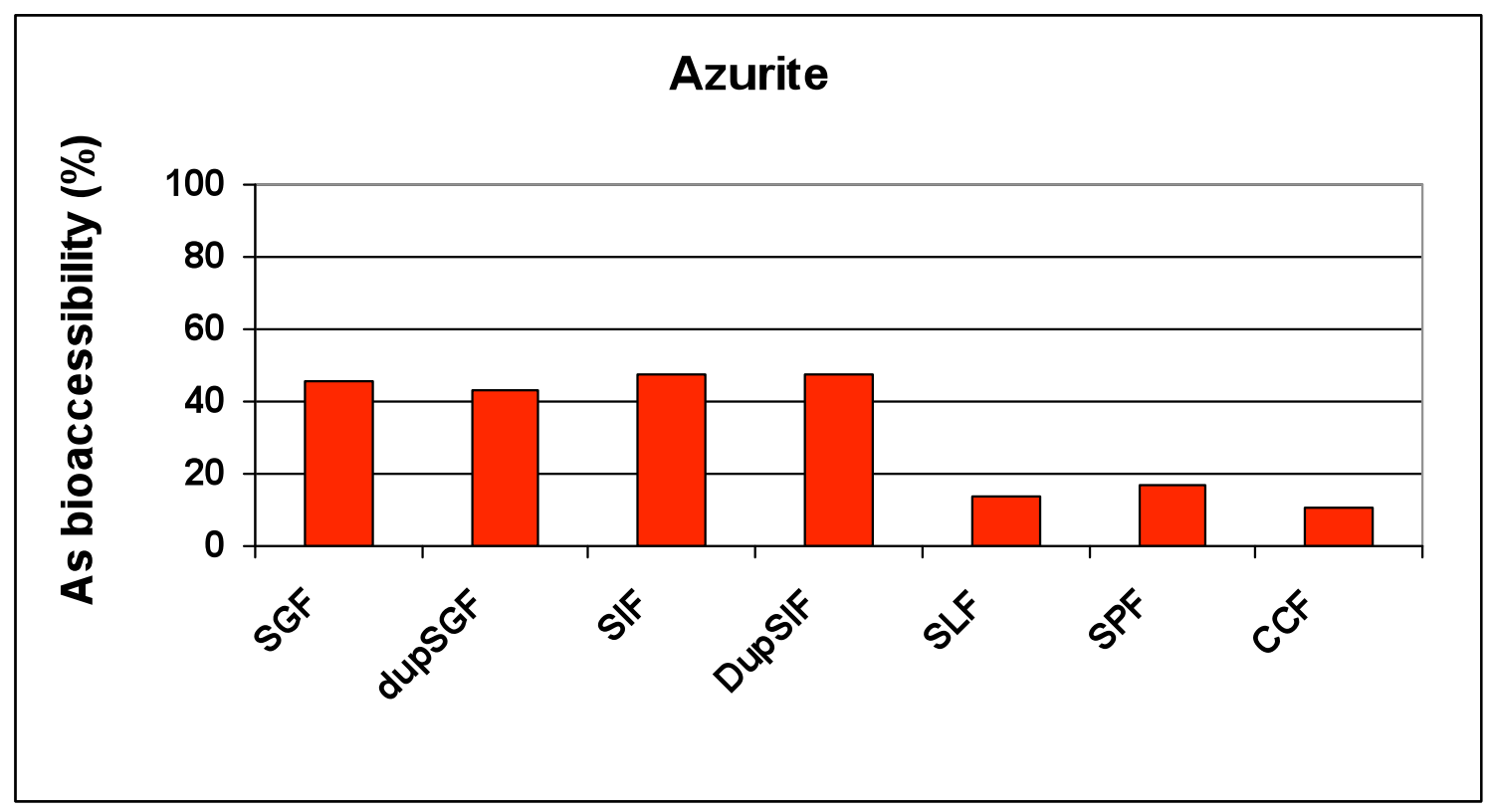

Figure 35. Bioaccessibility of arsenic in azurite, measured in simulated gastric fluid (SGF), intestinal fluid (SIF), lung fluid (SLF), phagolysosomal fluid (PSF) and cell carrier fluid (CCF) and presented as the per cent of the solid soluble in the fluid. 


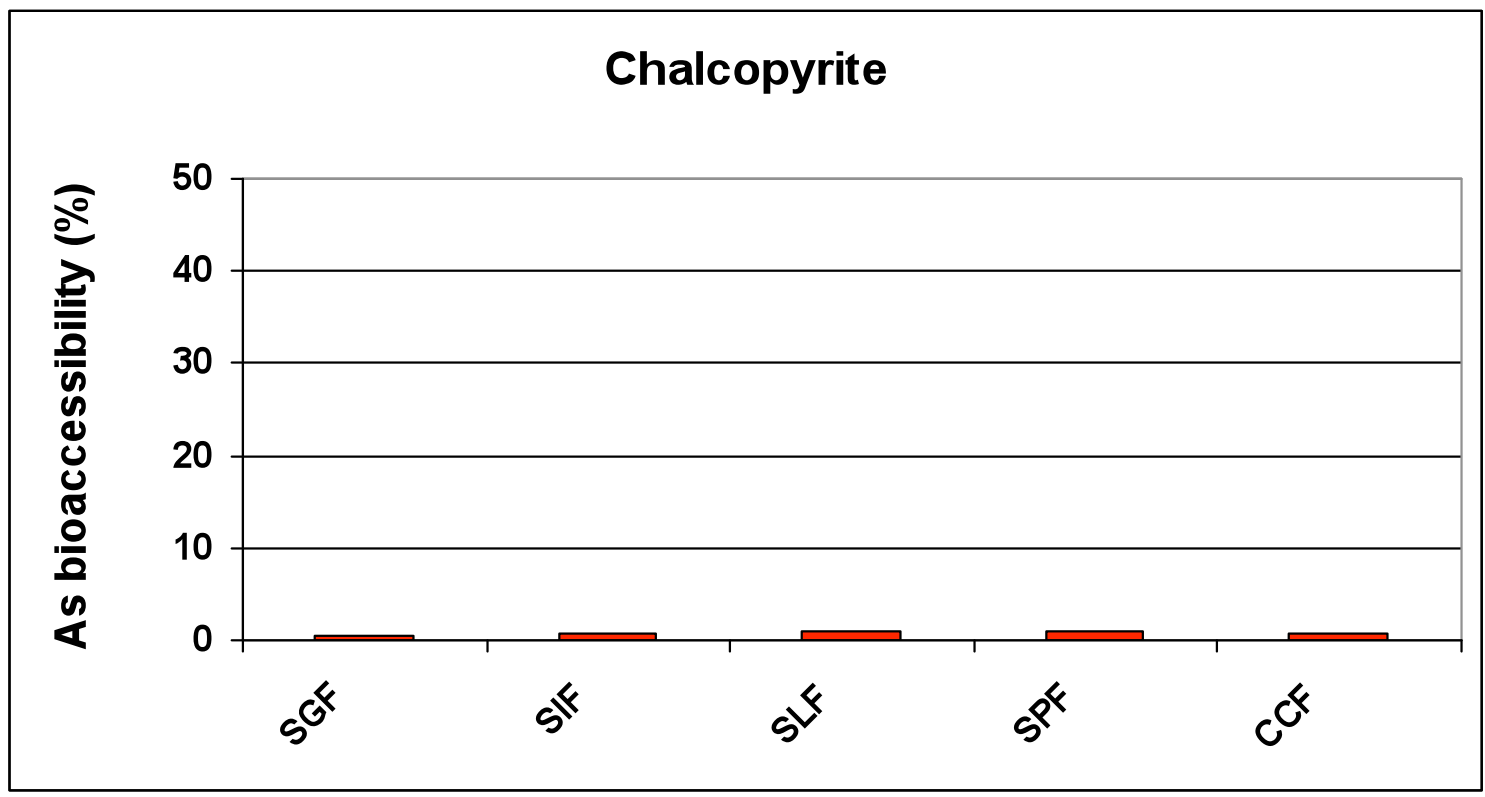

Figure 36. Bioaccessibility of arsenic in chalcopyrite, measured in simulated gastric fluid (SGF), intestinal fluid (SIF), lung fluid (SLF), phagolysosomal fluid (PSF) and cell carrier fluid (CCF) and presented as the per cent of the solid soluble in the fluid.

\section{Limitations of Results}

There are several limitations to the results of this study. Limited research has been conducted utilizing these simulated fluids to examine other exposure pathways, such as inhalation. Further, no uptake studies have been conducted to correlate how accurately the SLF and PSF mimic the complex physiological processes of the lung.

IVBA results express the amount of an element that is available to the body for uptake by target organs such as the kidneys and liver, but not the actual uptake. Many physiological factors control the uptake of elements by the body. To date, there are no reference values for comparison or determination of what is a high or low value. Finally, the minerals used in this study were ground, artificially creating fresh surfaces unlike minerals examined in a soil matrix, and lacking the additional controls on solubility present in such a matrix (particle size, soil $\mathrm{pH}$, the amount of organic carbon present, and the presence of clays, and Fe or Mn oxides) may produce artificially high solubility values for some trace metals.

\section{Summary}

Variations in the trace metal bioaccessibility observed in this study appear specific to the mineral, the $\mathrm{pH}$ of the extraction solution, or both. Many bioaccessibility studies have focused on understanding aspects of the soil matrix to identify factors that influence bioaccessibility. Studies that have examined mineralogy have, in general, focused on $\mathrm{As}, \mathrm{Cd}, \mathrm{Pb}$, and Zn (Ruby and others, 1999; Schaider and others, 2007). This study explored the bioaccessibility of copper-bearing minerals, and provides data which could assist in modeling and understanding variations in copper bioaccessibility. 


\section{Procedure for Determination of Metal Toxicity Using MetPLATETM}

\author{
Author: LaDonna M. Choate
}

\section{Introduction}

The leaching of metals from minerals in the environment can be toxic to aquatic organisms. Metal bioavailability and aquatic toxicity are a complex function of water chemistry (Sunda and Guillard, 1976). Factors that can affect metal toxicity are: metal concentration, competition with other cations $\left(\mathrm{Ca}^{2+}, \mathrm{Mg}^{2+}, \mathrm{Na}^{+}, \mathrm{K}^{+}, \mathrm{H}^{+}\right)$for biological uptake, and complexation by aqueous ligands ${ }^{2}$. Determination of the half maximal effective concentration $\left(\mathrm{EC}_{50}\right)$, defined as the concentration that produces a response in 50 percent of the exposed organisms due to the presence of metals, can be an expensive and time-intensive process if using standard test organisms. It is therefore beneficial to use a screening method to identify samples that may require more in-depth testing. MetPLATETM is an enzymatic bioassay kit that can be used to determine if the leaching of mineral(s) will release metal concentrations that produce toxic effects to Escherichia coli (E. coli) bacteria (Bitton and others, 1994). Toxicity is determined by the inhibition of the production of the enzyme $\beta$-galactosidase. When the $E$. coli bacteria are not stressed, they produce $\beta$-galactosidase which catalyzes the hydrolysis (fig. 37) of a colored chromogenic substrate (cholorphenol red- $\beta$-galactopyranoside), that in turn causes the color of the solution to change from yellow-orange to purple-red.

${ }^{2}$ a group, ion, or molecule coordinated to a central atom or molecule in a complex
When the bacteria are stressed by the presence of metals, their production of the enzyme is inhibited, and less of the colored chromogenic substrate is hydrolyzed. The amount of inhibition is determined by comparison of the color (purplered) of the sample, measured as absorbance at 575-nm wavelength, to that of a control having no inhibition. Figure 38 illustrates a developed MetPLATE ${ }^{\mathrm{TM}}$ test. Columns 1 and 2 are controls, and columns 3 to 12 are samples. Each sample column represents an individual sample with varying concentrations of a toxic substance, in this case copper. The copper concentration decreases going down the column from rows $\mathrm{A}$ to $\mathrm{H}$. The inhibition (directly related to toxicity) decreases with decreasing concentration. Less toxic samples produce a darker color and higher measured absorbance. Absorbance is used to determine the $\mathrm{EC}_{50}$ for the E. coli.

\section{General Method}

The MetPLATETM test kit obtained from MetPLATE LLC (Gainesville, Fla.) is refrigerated until the day of use, when it is removed and allowed to warm to room temperature. The copper-bearing mineralogic samples were leached using the USGS FLT (see Hageman, this volume). Twenty to fifty $\mathrm{mL}$ of the leachate was used for the MetPLATE ${ }^{\mathrm{TM}}$ toxicity test. Dilutions were made by taking $10 \mathrm{~mL}$ of the leachate, adding $10 \mathrm{~mL}$ of diluent-EPA moderately hard water (USEPA, 1994b) —and vortexing for 10 seconds. Subsequent dilutions were preformed using this procedure (beginning with the previous dilution) until the required dilutions were obtained. The test samples were prepared by transferring a $0.9 \mathrm{~mL}$ aliquot of the undiluted sample and each of the dilutions into test tubes and adding $0.1 \mathrm{~mL}$ of the reconstituted bacterial reagent (E. coli). The controls were prepared by adding $0.1 \mathrm{~mL}$ of bacterial reagent to test tubes containing $0.9 \mathrm{~mL}$ of diluent for the negative control and $0.9 \mathrm{~mL}$ of a

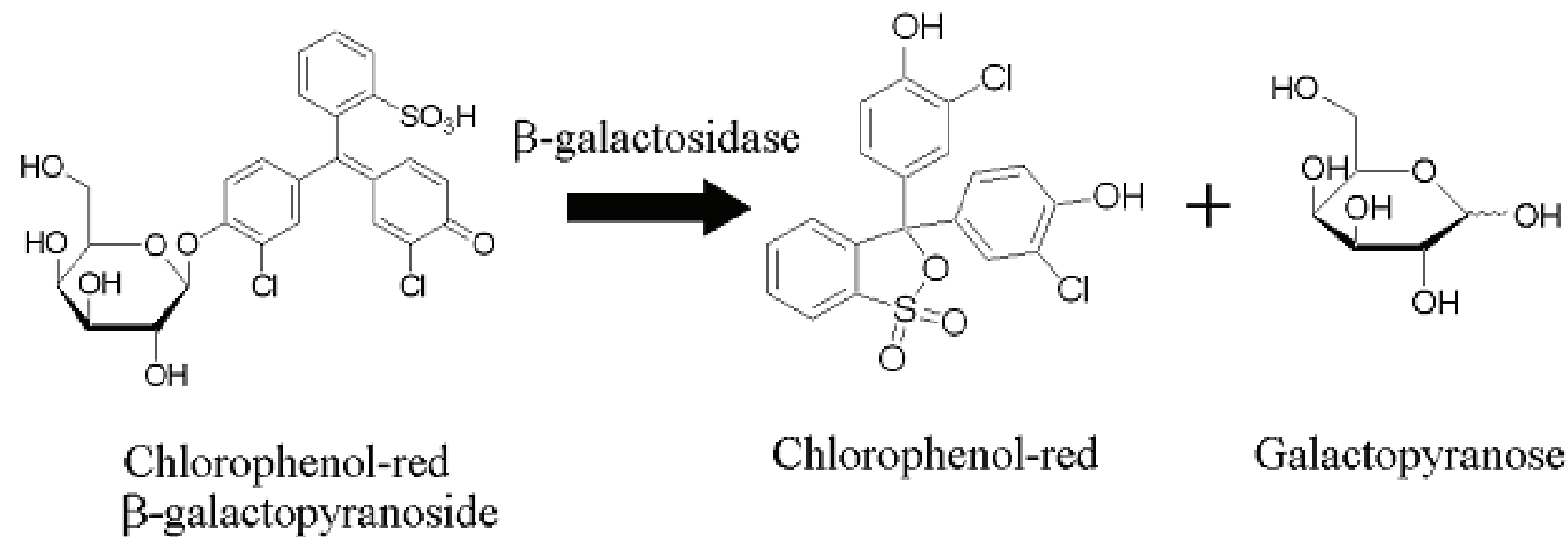

Figure 37. ß-galactosidase catalyzed hydrolysis of chlorophenol red-ß-galactopyraniside (Bitton and Koopman, 1997; Rossel and others, 1997; Ward and others, 2005). 


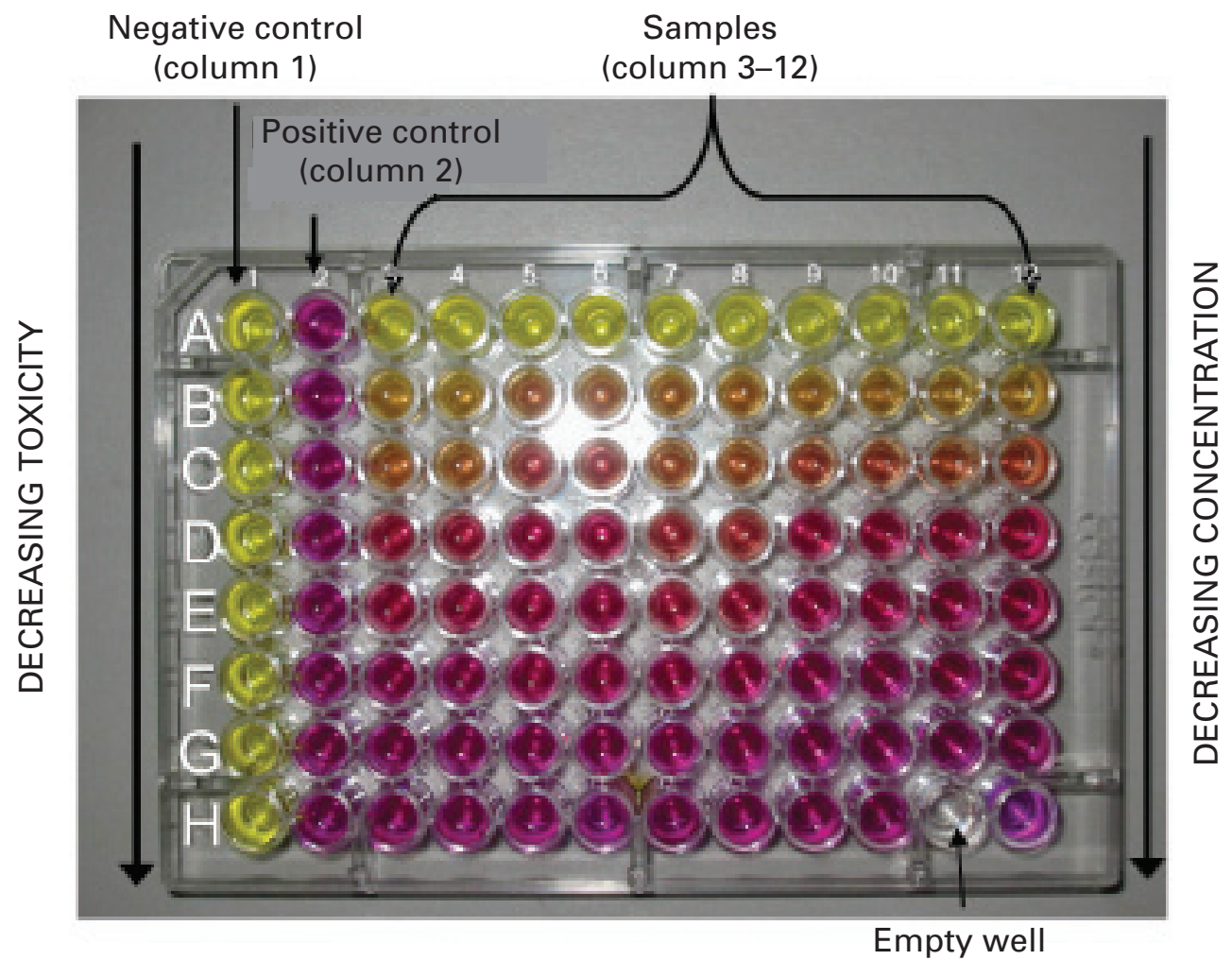

Figure 38. A developed 96-well MetPLATE ${ }^{T M}$ bioassay, showing negative (toxic) and positive (non-toxic) controls and dilution series for several water samples.

standard copper sulfate solution at toxic levels for the positive control. All sample tubes were vortexed for 10 seconds and incubated at $35^{\circ} \mathrm{C}$ for 90 minutes. After incubation, $0.2 \mathrm{~mL}$ of sample was pipetted into the corresponding well in the 96-well microplate (fig. 38) and $0.1 \mathrm{~mL}$ of the reconstituted chromogenic substrate was added to each well.

The microplate is incubated at $35^{\circ} \mathrm{C}$ and the absorbance is measured at $575 \mathrm{~nm}$ every 15 minutes over the course of 2 hours, using a BioTeK PowerWave 350X spectrophotometer and KCjunior ${ }^{\mathrm{TM}}$ software. When the absorbance for the negative control is greater than four, the data from the previous time interval is used to determine the $\mathrm{EC}_{50}$ for the sample. The positive control has the maximum effect-100-percent inhibition of $\beta$-galactosidase production-thus the absorbance should be zero. However, the non-hydrolyzed chromogenic substrate has some color and produces an absorbance value, positive control (fig. 39). The absorbance for all concentrations has been corrected for maximum toxicity by subtracting the absorbance of the positive control absorbance. The percent inhibition is calculated for each sample using the following equation:

$\%$ Inhibition $=(1-(($ Sample Absorbance $) /($ Control Absorbance)) x 100
The control absorbance is the absorbance of the negative control, but as seen in figure 39 the absorbance is greater for the lowest concentrations of the copper minerals. This implies that the leachate matrices contain other elements or compounds that enhance their absorbance at $575 \mathrm{~nm}$. To account for this matrix effect the highest absorbance for each leachate is used as the control absorbance. A plot of metal concentration versus percent inhibition can then be used to determine the metal concentration where half of the $E$. coli is affected, $\mathrm{EC}_{50}$.

\section{Summary}

The data for the four minerals have been plotted as the major metal concentration verses the percent inhibition. Since the goal was to investigate the overall toxicity of the leachates and environmental dilution, and not specific metals, the samples were diluted with diluent. The $\mathrm{pH}$ for all of the 100 -percent leachates was greater than or equal to 5.9 ; the MetPlate is for use with solutions of $\mathrm{pH} 5.0$ to 7.5; three of the 100-percent leachates (azurite, bornite, and malachite) had $\mathrm{pH}$ values greater than 7.5 but the $\mathrm{pH}$ was not adjusted at any point. Copper is the major metal for the azurite, 


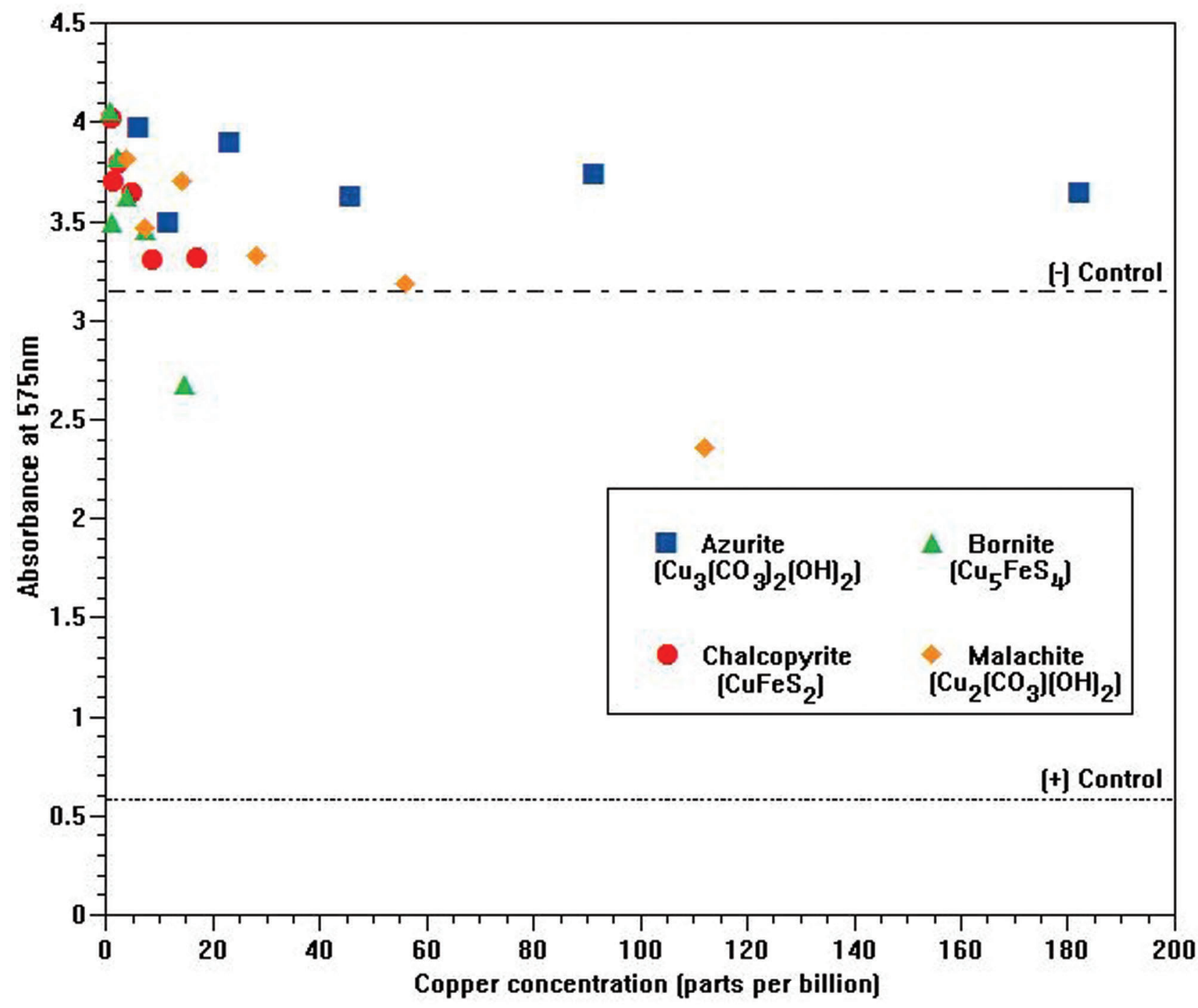

Figure 39. Absorbance at 575-nm of serial dilutions of the USGS-FLT solutions compared to the copper concentrations ( $\mu \mathrm{g} / \mathrm{L}$ ) for the copper minerals.

chalcopyrite, bornite and malachite minerals. A plot of copper concentration versus percent inhibition is shown in figure 40 . This figure shows that the maximum copper concentration is less than 50-percent inhibition for the leachate and leachate dilutions of the azurite, chalcopyrite, bornite, and malachite specimens. Therefore, it is not possible to determine an $\mathrm{EC}_{50}$ for these minerals because it is necessary to bracket the 50-percent inhibition. Lines for the linear regression of the copper data are shown in figure 41 . This shows that the different minerals, even after copper normalization, have different inhibition (toxicity) responses, because the slopes of the lines are different. At much higher copper concentrations, the azurite and malachite are less toxic then the chalcopyrite and bornite. There is something else in the matrix that is modifying their toxicity. The carbonate in the azurite and malachite could be forming soluble complexes with the metals, where the iron sulfide in the chalcopyrite and bornite does not have this complexing effect. This is not an effect of $\mathrm{pH}$ since the $\mathrm{pH}$ values for the 100-percent leachate are as follows: chalcopyrite is 5.9 , bornite is 8.2 , malachite is 8.1 , and azurite is 9.1. If the $\mathrm{pH}$ was the cause, the slope of the line for the bornite should be similar to that of malachite.

A summary of the MetPLATE ${ }^{\mathrm{TM}} \mathrm{EC}_{50}$ is given in table 5 . The MetPLATE ${ }^{\mathrm{TM}}$ results indicate that further aquatic toxicity testing for bornite and chalcopyrite could aid in evaluating their environmental toxicity potential. 


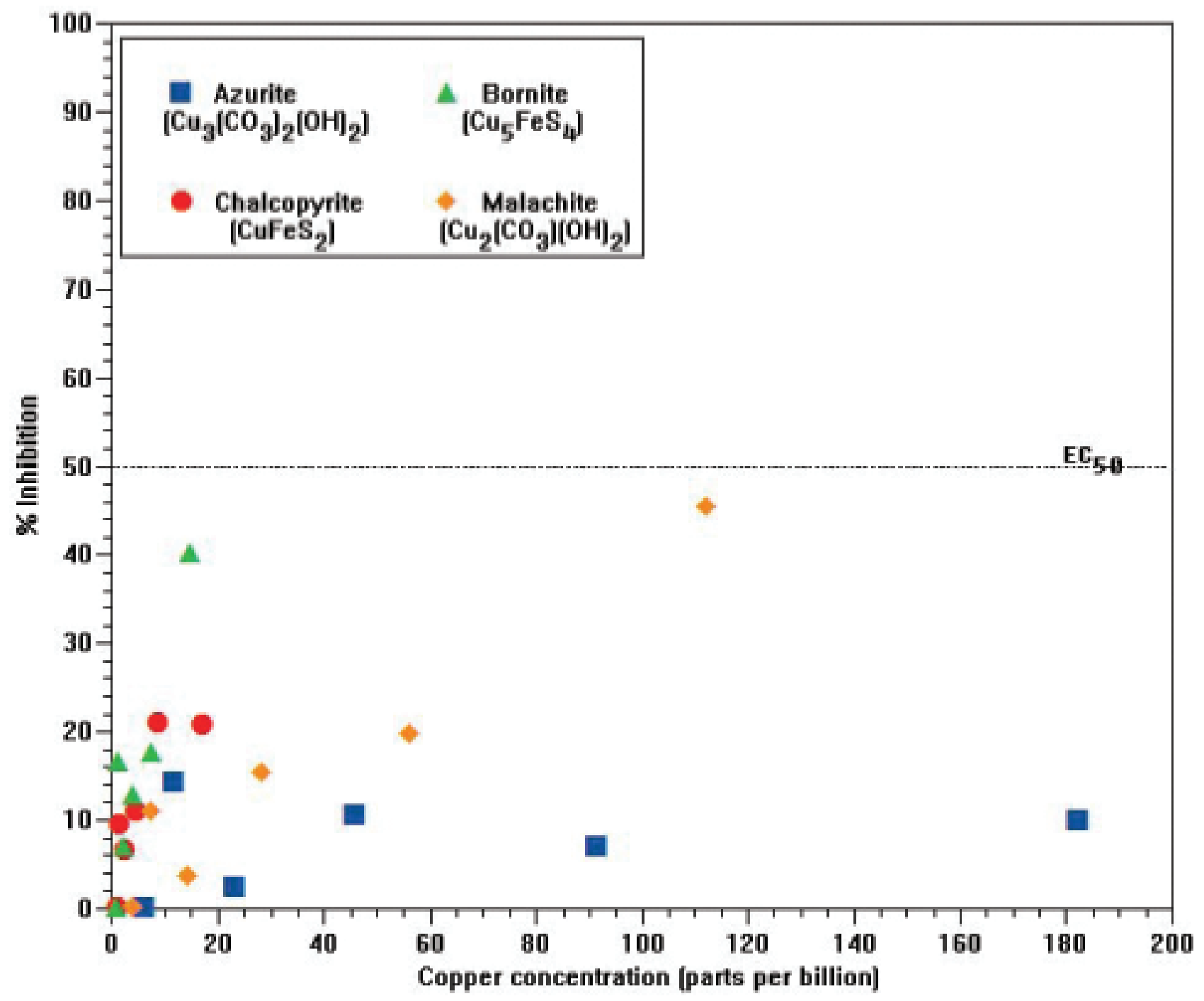

Figure 40. Percent Inhibition of serial dilutions of the USGS-FLT solutions compared to the copper concentrations ( $\mu \mathrm{g} / \mathrm{L}$ ) for the copper minerals.

Table 5. Summary of the $\mathrm{EC}_{50}$ values for four copper-bearing minerals.

[nc, no chronic toxicity at the leach concentration; $\mathrm{EC}_{50}$, outside of the concentration range]

\begin{tabular}{l|c|c|c|c}
\hline Element & \multicolumn{4}{|c}{ Copper } \\
\hline Mineral & Azurite & Chalcopyrite & Bornite & Malachite \\
$\mathrm{EC}_{50}$ & $\mathrm{nc}$ & $\mathrm{nc}$ & $\mathrm{nc}$ & $\mathrm{nc}$ \\
\hline
\end{tabular}




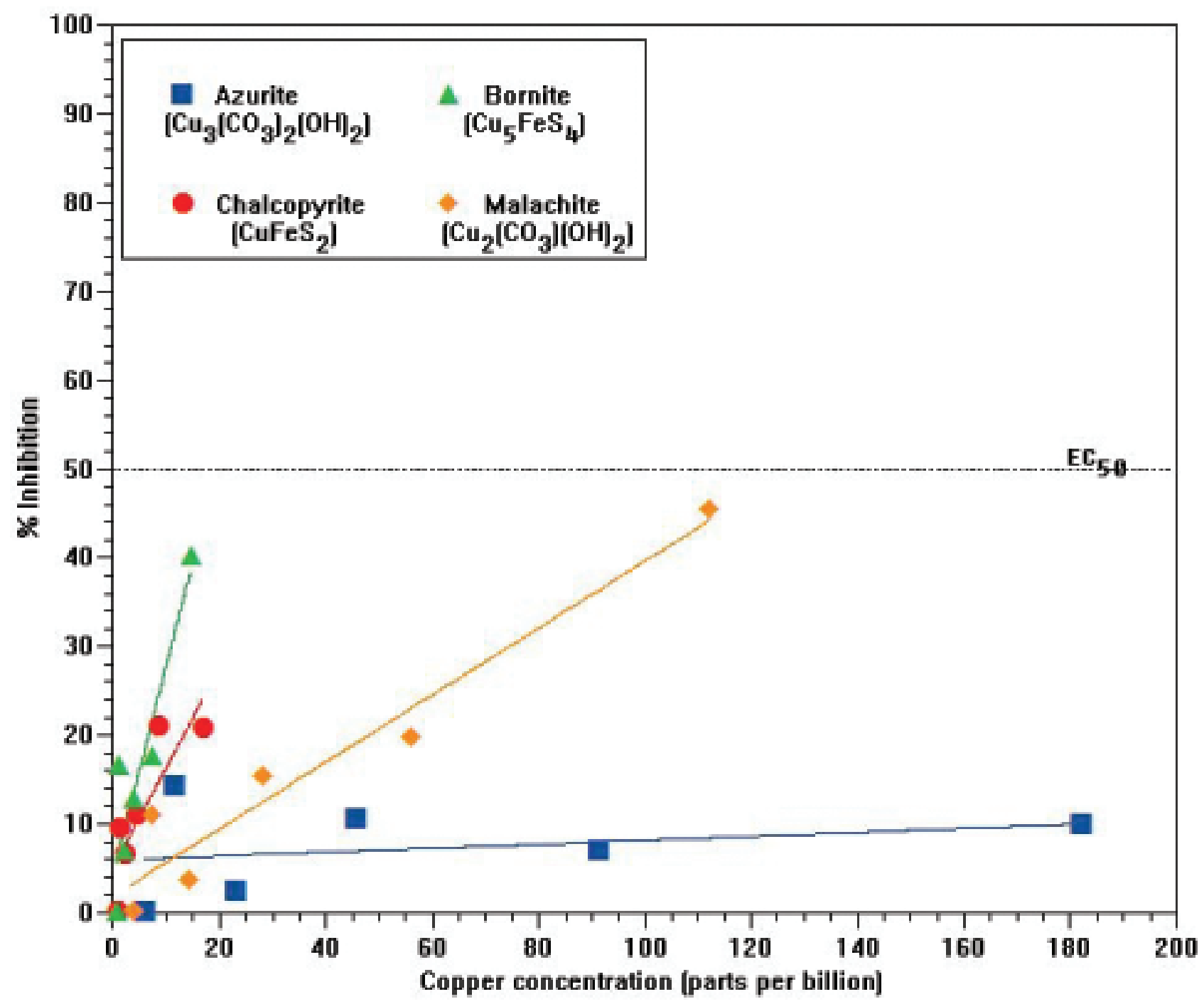

Figure 41. Percent Inhibition of serial dilutions of the USGS-FLT solutions compared to the copper concentrations ( $\mu \mathrm{g} / \mathrm{L}$ ) for the copper minerals, with linear regression shown. 


\section{Conclusion}

The purpose of this study was fourfold: To elucidate the microscopic properties of four common $\mathrm{Cu}$-bearing minerals, to ascertain the chemical composition and investigate the toxic potential of those same four minerals, and to compile a reference of standard analytical methods.

The first of our objectives was conducted using X-ray diffractometry and other microanalytical techniques. The $\mathrm{X}$-ray diffractograms and Rietveld pie-charts that appear in the Mineralogical Analyses section provide phase identity and quantity data for each of the four study specimens, and provide limited information about amorphous or non-crystalline components. The series of micrographs confirm phase identities, provide micro-textural and -structural information, and pinpoint residence sites of potentially toxic elements.

We achieved our second objective through a series of geochemical studies. Bulk chemistry analysis yielded valuable information about the actual chemical composition of each of the four minerals. Three leachate tests (FLT, SPLP $\mathrm{pH}$ 4.2, and SPLP $\mathrm{pH}$ 5.0) provided specific conductance and $\mathrm{pH}$ data for each specimen while a separate digestion experiment showed that leachable copper (copper that is liberated by interaction with water or some other aqueous solution) represents only a small fraction of total copper detected in each sample. All of the data collected from the geochemical experiments indicate that the copper-bearing minerals examined in this study are soluble acid producers that contain traces of suspected toxic elements.

Compositional analyses were followed by specific toxicity studies. The first study focused on the bioaccessibility, or reactivity, of mineral materials in simulated human body fluids. Through laboratory experiments we learned that certain common base metals are soluble in the acidic fluids of the human digestive systems, but that those same base metals may be less reactive in the neutral $\mathrm{pH}$ environment of the lungs.

The bioaccessibility study provides an estimate of element solubility in physiologically based fluids and may be important for future modeling studies. There is currently no scale by which to evaluate these concentrations, although the gastric IVBA has been accepted by the EPA to evaluate bioaccessibility and calculate relative bioavailability of lead. It is likely that continued development and correlation of IVBA studies with animal models will provide acceptance of the method for other metals.

The final experiment addressed the issue of metal toxicity using a trademarked bioassay kit. The objective of this work was to quantify production of an important intestinal enzyme. The enzyme, B-galactosidase, facilitates conversion of the complex milk sugar, lactose, into glucose and galactose (simple-sugar compounds). By exposing E. coli bacteria to systematic dilutions of the FLT leachate it was possible to correlate enzyme production with known concentrations of leached metals. The findings of the E. coli study suggest a probable link between enzymatic health and exposure to metal toxins.

In addition to yielding information about the structure, composition, and toxic potential of the four minerals, the study also produced a catalog of scientific methods. By furnishing step-by-step procedural instructions, we have provided an inquiring public with means to authenticate results or to conduct independent research. All of the experiments can be reproduced using minerals found in every terrain and environment.

It is important to note that the datasets contained in this report do not extend to minerals from other localities; what is true for the chalcopyrite analyzed for this report will not be true for a chalcopyrite from a different location. Minerals of the same name but from different localities can have a different trace-element composition, can host dissimilar micro minerals, and can even have a variant unit cell. To demonstrate the veracity of this statement we did a simple comparison of select physical properties and locality descriptions of three chalcopyrite specimens.

The chalcopyrite analyzed for this report came from the Leonard Mine in the Copper District of Butte, Montana. Chalcopyrite from this geologic district often exhibits covellite $(\mathrm{CuS})$ alteration, a bluish, or indigo, iridescence on crystal faces. Covellite is a supergene mineral found in the sulfide zones of copper deposits. It is an alteration product of chalcopyrite or bornite. Conditions in the Butte Copper District facilitate alteration of chalcopyrite to covellite as evidenced by the distinctive blue tarnish seen on chalcopyrite specimens from the region.

About 380 miles south of Butte, at the Bingham Canyon Copper District in Utah, chalcopyrite occurs throughout granite-like host rock as tiny grains and seams. The Bingham Canyon porphyry has rarely produced a notable chalcopyrite specimen. Chalcopyrite from this district is unremarkable apart from occurring in the world's largest open pit mine (at the time of this paper).

Still farther south of Butte at the San Pedro Mine in Golden, New Mexico, chalcopyrite specimens occur as nonmetallic black crystals surrounding a pyrite core (Tripp, verbal comm., January 19, 2011). This distinctive chalcopyrite derives from a skarn deposit. It occurs in association with coarse gold nuggets and garnets in placers of dry alluvium.

It is apparent from the observations cited above that variations in conditions are responsible for variations in physical properties and, most likely, variations in mineral composition. An assessment of the kind described in this report of the three chalcopyrite specimens would provide further evidence of their unique character or dissimilarities. Thus, for a mineral assessment to have local value, the assessed mineral or minerals should come from the locality of interest or at least a locality of similar type. The randomly selected $\mathrm{Cu}$-bearing minerals used for this study suggest that the methods described herein are reliable and, most important, applicable to nearly all minerals. 
On a large scale we value minerals as commodities or as aesthetically pleasing objects. It isn't until we examine minerals at the microscopic level that we begin to recognize the potential of minerals to adversely affect not only the health of ecosystems, but also human health. As demonstrated in this study, examination of minerals at the microscopic level resolves questions related to precise composition, solubility, acid-generating or -neutralizing potential, and latent toxicity. What we learn about naturally occurring minerals through optical, chemical, and biological investigations allows us to trace elements to their source and to improve our ability to remediate or forestall contamination of living systems. Knowing how minerals behave in the physical world is an advantage and an opportunity for geoscientists. The advantage is the ability to predict effect; the opportunity lies in proposing or developing alternatives or remedies should the demonstrated effect compromise living systems.

With this study of four copper-bearing minerals we have shown that none of the specimens was "pure;" that all were structurally imperfect; that all were, in some ways, chemically similar; that, under normal weathering conditions, each produces acid; that inherent select elements are reactive; and that toxicity is proportionate to element concentration. All of this information can be used to further our understanding of the effects of not just dispersed metals, but of minerals on human and environmental health.

\section{Selected References}

Al-Abed, S.R., Hageman, P.L., Jegadeesan, G., Madhavan, N., and Allen, D., 2005, Comparative evaluation of short-term leach tests for heavy metal release from mineral processing waste: Science of the Total Environment, v. 364, p. 14-23.

Alpers, Charles N., and Hunerlach, Michael P., 2005, Mercury contamination from historic gold mining in California: U.S. Geological Survey Fact Sheet FS-061-00. Available on-line at http://ca.water.usgs.gov/mercury/fs06100.html.

Ansoborlo, E., Henge-Napoli, M.H., Chazel, V., Gilbert, R., and Guilmette, R.A., 1999, Review and critical analysis on available in vitro dissolution tests: Health Physics, v. 77 (6), p. 638-645.

Basta, N.T., Foster, J.N., Dayton, E.A., Rodriguez, R.R., and Casteel, S.W., 2007, The effect of dosing vehicle on arsenic bioaccessibility in smelter-contaminated soils: Journal of Environmental Science and Health, Part A, v. 42 (9), p. $1275-1281$.

Bitton, G., Jung, K., and Koopman, B., 1994, Evaluation of a microplate assay specific for heavy metal toxicity: Archives of Environmental Contamination and Toxicology, v. 27, p. 25-28.

Bitton, G., and Koopman, B., 1997, Assay pad and method for determination of the presence of total coliforms: Patent 5633144, filed 7/19/1994.
Brett, R. and Yund, R.A., 1964, Sulfur rich bornites: American Mineralogist, v. 49, p. 1084-1098.

Brown, Z.A., and Curry, J.K., 2002a, Total carbon by combustion, chap. R, in Taggart, J.E., Jr., ed., Analytical methods for chemical analysis of geologic and other materials: U.S. Geological Survey Open-File Report 02-0223. Available online at http://pubs.usgs.gov/of/2002/ofr-02-0223/.

Brown, Z.A., and Curry, J.K., 2002b, Total sulfur by combustion, chap. Q, in Taggart, J.E., Jr., ed., Analytical methods for chemical analysis of geologic and other materials: U.S. Geological Survey Open-File Report 02-0223. Available online at http://pubs.usgs.gov/of/2002/ofr-02-0223/.

Carrizales, L., Razo, I., Tellez-Hernandez, J.I., Torres-Nerio, R., Torres, A., Batres, L.E., Cubillas, A., and DiazBarriga, F., 2006, Exposure to arsenic and lead of children living near a copper-smelter in San Luis Potosi, Mexico: Importance of soil contamination for exposure of children: Environmental Research, v. 101, p. 1-10.

Chowdhury, U.K., Biswas, B.K., Chowdhury, T.R., Samanta, G., Mandal, B.K., Basu, G.C., Chandra, C.R., Lodh, D., Saha, K.C., Mukherjee, S.K., Roy, S., Kabir, S., Quamruzzaman, Q., and Chakraborti, D., 2000, Groundwater arsenic contamination in Bangladesh and West Bengal, India: Environmental Health Perspective, v. 108(5), p. 393-397.

Diehl, S.F., Hageman, P.L., and Smith, K.S., 2006, What's weathering? Mineralogy and field leach studies in mine waste, Leadville and Montezuma mining districts, Colorado, in Barnhisel, R.I., ed., Proceedings of the Seventh International Conference on Acid Rock Drainage (ICARD 7), St. Louis, Missouri, March 26-30, 2006, p. 507-527. Available online at http://www.imwa.info/docs/imwa_2006/0507Diehl-CO.pdf.

Diehl, S.F., Hageman, P.L., Smith, K.S., Koenig, A.E., Fey, D.L., and Lowers, H.A., 2007, What's weathering in mine waste? Mineralogic evidence for sources of metals in leachates, in Barnhisel, R.I., ed., Proceedings of the Hard Rock 2006 Conference, Tucson, Arizona, November 14-16, 2006: U.S. Environmental Protection Agency, Interactive Hard Rock Mining 2006 Conference CD-ROM (EPA/625/C-07/003).

Diehl, S.F., Koenig, A.E., Hageman, P.L., Smith, K.S., Fey, D.L., and Lowers, H.A., 2007, From the micro to the macro scale: a textural and chemical perspective of characterizing waste-rock material: Society for Mining, Metallurgy, and Exploration, Inc. (SME) Annual Meeting, February 25-28, 2007, Denver, CO, CD ROM, 16 p.

Drexler, J.W., and Brattin, W.J., 2007, An in vitro procedure for estimation of lead relative bioavailability: with validation: Human and Ecological Risk Assessment, v. 13, p. 383-401. 
Hageman, Philip L., 2007a, U.S. Geological Survey field leach test for assessing water reactivity and leaching potential of mine-wastes, soils, and other geologic and environmental materials: U.S. Geological Survey Techniques and Methods, book 5, chap. D3, 14 p. Available online at http://pubs.usgs. gov/tm/2007/05D03/.

Hageman, Philip L., 2007b, Determination of mercury in aqueous and geologic materials by continuous flow-coldvapor-atomic fluorescence spectrometry (CVAFS): U.S. Geological Survey Techniques and Methods, book 5, chap. $\mathrm{D} 2,6 \mathrm{p}$.

Herting, G., Wallinder, O., and Leygraf, C., 2006, Factors that influence the release of metals from stainless steels exposed to physiological media: Corrosion Science, v. 48, p. 2120-2132.

Jade Software, 3D Crystal Structure Viewer, Materials Data Inc. Jade Plus version 9 software, copyright 2011, www. materialsdata.com.

Kanapilly, G.M., Raabe, O.G., Goh, C.H.T., and Chimenti, R.A., 1973, Measurement of in vitro dissolution of aerosol particles for comparison to in vivo dissolution in the lower respiratory track after inhalation, Health Physics, v. 24, p. 497-507.

Karczewska, A., 1996, Metal species distribution in top and sub-soil in an area affected by copper smelter emissions: Applied Geochemistry, v. 11, p. 35-42.

Kim, K.R., Owens, G., and Naidu, R., 2009, Heavy metal distribution, bioaccessibility, and phytoavailability in longterm contaminated soils from Lake Macquarie, Australia: Australian Journal of Soil Research, March 2009. Available online at http:// findarticles.com/p/articles/mi_hb3364/ is_2_47/ai_n32145974/?tag=content;col1.

Kreyling, W., 1992, Intracellular particle dissolution in alveolar macrophages: Environmental Health Perspectives, v. 97 , p. $121-126$.

Lamothe, P.J., Meier, A.L., and Wilson, S., 2002, The deter $\neg$ mination of forty-four elements in aqueous samples in inductively coupled plasma-mass spectrometry, chap. $\mathrm{H}$, in Taggart, J.E., Jr., ed., Analytical methods for chemical analysis of geologic and other materials: U.S. Geological Survey Open-File Report 02-0223. Available online at http://pubs.usgs.gov/of/2002/ofr-02-0223/.

Lapakko, Kim, and Lawrence, R.W., 1993, Modifications of the net acid production (NAP) test: Proceedings of the Seventeenth Annual British Columbia Mine Reclamation Symposium, Port Hardy, British Columbia, 1993, p. 145-159.
Mattson, S., 1994, Glass fibers in simulated lung fluid: dissolution behavior and analytical requirements: Annals of Occupational Hygiene, v. 38, p. 857-877.

Morman, S., Plumlee, G.S., and Smith, D.B., 2009, Application of in vitro extraction studies to evaluate element bioaccessibility in soils from a transect across the United States and Canada: Applied Geochemistry, v. 24 (8), p. 1454-1463.

Pizarro, F., Olivares, M., Gidi, V., and Araya, M., 1999, The gastrointestinal tract and acute effects of copper in drinking water and beverages: Reviews on Environmental Health, v. 14 (4), pp. 231-238.

Rossel, D., Tarradellas, J., Bitton, G., and Morel, J.L., 1997, Use of Enzymes in Soil Ecotoxicology: A case for dehydrogenase and hydrolytic enzymes: Soil Ecotoxicology, CRC Press, Boca Raton, FL., p. 179-206.

Ruby, M.V., Davis, A., Link, T., Schoof, R., Chaney, R., Freman, G., Bergstrom, P., 1993, Development of an in vitro screening test to evaluate the in vivo bioaccessibility of ingested mine-waste lead: Environmental Science and Technology, v. 27, p. 2870-2875.

Ruby, M.V., Davis, A., Schoof, R., Eberle, S., Sellstone, C., 1996, Estimation of lead and arsenic bioavailability using a physiologically based extraction test, Environmental Science and Technology, v. 30, p. 422-430.

Ruby, M.V., Schoof, R., Brattin, W., Goldade, M., Post, G., Harnois, M., Mosby, D.E., Casteel, S.W., Berti, W., Carpenter, M., Edwards, D., Cragin, D., Chappell, W., 1999, Advances in evaluating the oral bioavailability of inorganics in soil for use in human health risk assessment. Environmental Science and Technology, v. 33, p. 3697-3705.

Schaider, L., Senn, D., Brabander, D., McCarthy, K., Shine, J., 2007, Characterization of zinc, lead and cadmium in mine waste: implications for transport, exposure, and bioavailability: Environmental Science and Technology, v. 41, p. 4164-4171.

Stefaniak, A., Day, G., Hoover, M., Breysse, P., and Scripsick, R., 2006, Differences in dissolution behavior in a phagolysosomal fluid for single constituent and multi-constituent materials associated with beryllium sensitization and chronic beryllium disease: Toxicology in Vitro, v. 20, p. 82-95.

Sun, G., Crissman, K., Norwood, J., Richards, J., Slade, R., and Hatch, G., 2001, Oxidative interactions of synthetic lung epithelial lining fluid with metal containing particulate matter: American Journal of Physiology Lung Cellular Molecular Physiology, v. 281, p. 807-815. 
Sunda, W.G., and Guillard, R.R.L., 1976, The relationship between cupric ion activity and the toxicity of copper to phytoplankton: Journal of Marine Research, v. 34, p. 511-529.

Theodorakos, P.M., d'Angelo, W.M., and Ficklin, W.H., 2002, Fluoride, chloride, nitrate, and sulfate in aqueous solution by using AutoSuppression chemically suppressed ion chromatography, chap. V, in Taggart, J.E., Jr., ed., Analytical methods for chemical analysis of geologic and other materials: U.S. Geological Survey Open-File Report 02-0223. Available online at http://pubs.usgs.gov/of/2002/ ofr-02-0223/.

U.S. Environmental Protection Agency (USEPA), 1994, Synthetic Precipitation Leaching Procedure (SW-846), revision 1, September, 1994. Last accessed February 16, 2008, at URL http://www.epa.gov/osw/hazard/testmethods/sw846/ pdfs/1312.pdf.

U.S. Environmental Protection Agency, 1994b, Short-term methods for estimating the chronic toxicity of effluents and receiving waters to freshwater organisms (3d ed): Environmental Monitoring Systems Laboratory, Cincinnati, $\mathrm{OH}$, July 1994. URL http://www.EPA/600/4-91/002.

U.S. Environmental Protection Agency (USEPA), 2004, Toxicity characteristic leaching procedure, (SW-846), revision 6, November, 2004. Last accessed February 12, 2008, at
URL http://www.epa.gov/osw/hazard/testmethods/sw846/ pdfs/1311.pdf.

U.S. Environmental Protection Agency (USEPA), 2008a, Standard operating procedure for an in vitro bioaccessibility assay for lead in soil: EPA 9200.1-86, November 2008. Available on-line at http://www.epa.gov/superfund/bioavailability/pb_ivba_sop_final.pdf.

U.S. Geological Survey, 1995, Natural environmental effects of silver-lead-zinc deposits in the Brooks Range, Alaska: U.S. Geological Survey Fact Sheet FS-092-95. Available on-line at http://pubs.usgs.gov/fs/fs-0092-95/.

Van Wijnen, J.H., Clausing, P., and Brunekreef, B., 1990, Estimated soil ingestion by children: Environmental Research, v. 51, p. 147-162.

Ward, Marnie L., Bitton G., and Townsend T., 2005, Heavy metal binding capacity (HMBC) of municipal solid waste landfill leachates: Chemosphere, v. 60, p. 206-215.

Weber, P.A., Hughes J.B., Conner L.B., Lindsay, P., and Smart, R., 2006, Short-term acid rock drainage characteristics determined by paste $\mathrm{pH}$ and kinetic NAG testing: Cypress prospect, New Zealand, in Barnhisel, R.I., ed., Proceedings of 7th ICARD, St Louis, March 2006, p. 2289-2295.

Young, R.A. ed., 1995, The Rietveld Method: International Union of Crystallography, Oxford University Press, 298 p. 


\section{Appendix A}

\section{Digital Photographs of Copper Minerals}

Four Copper-Bearing Minerals Prior to Reduction and Analysis Distribution

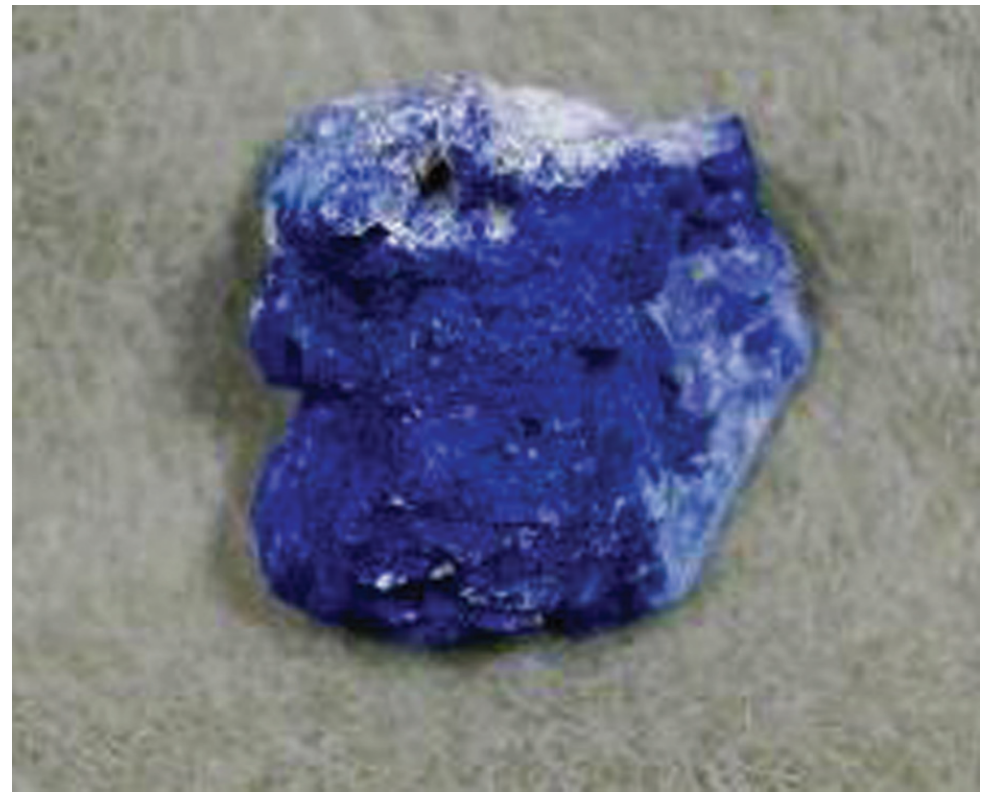

Azurite, Anhui Province, China

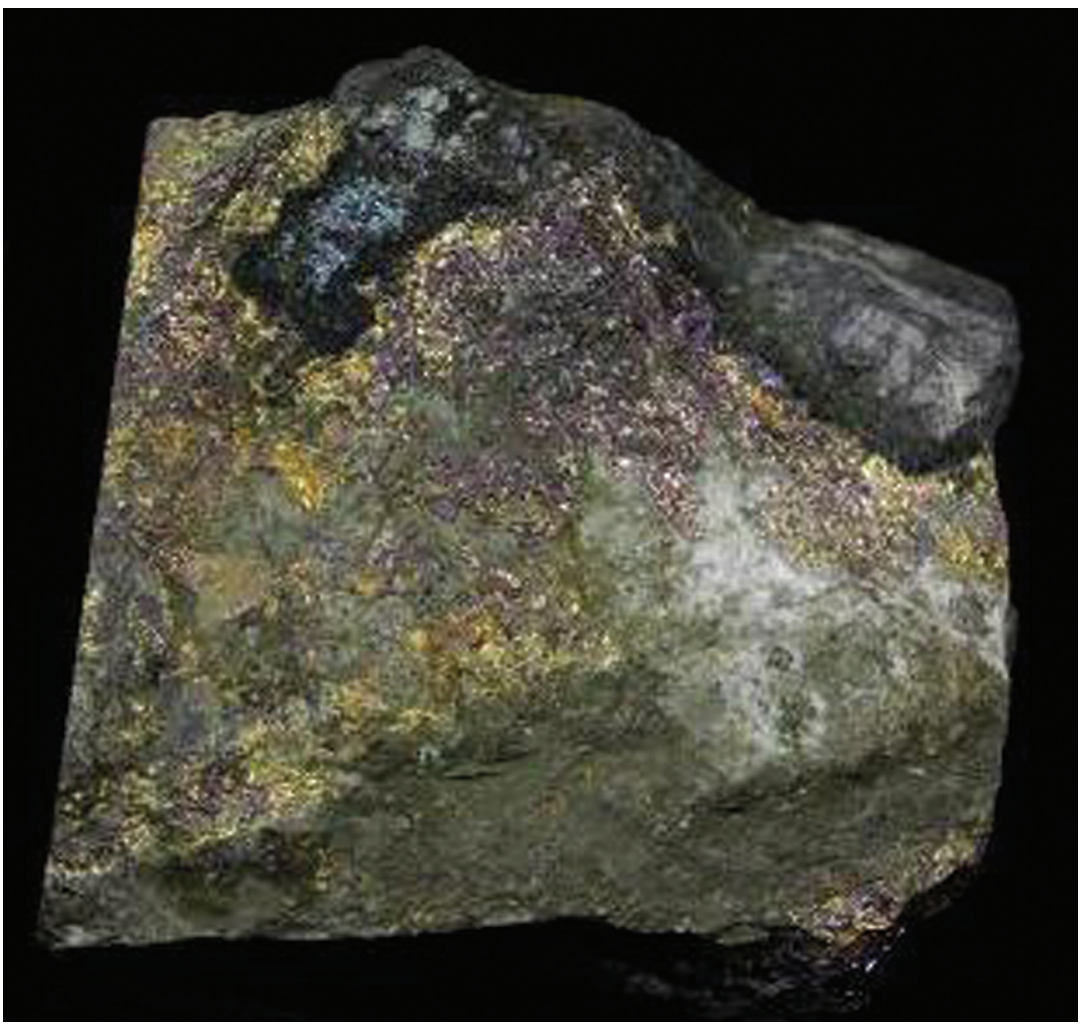

Bornite, Superior, Arizona 


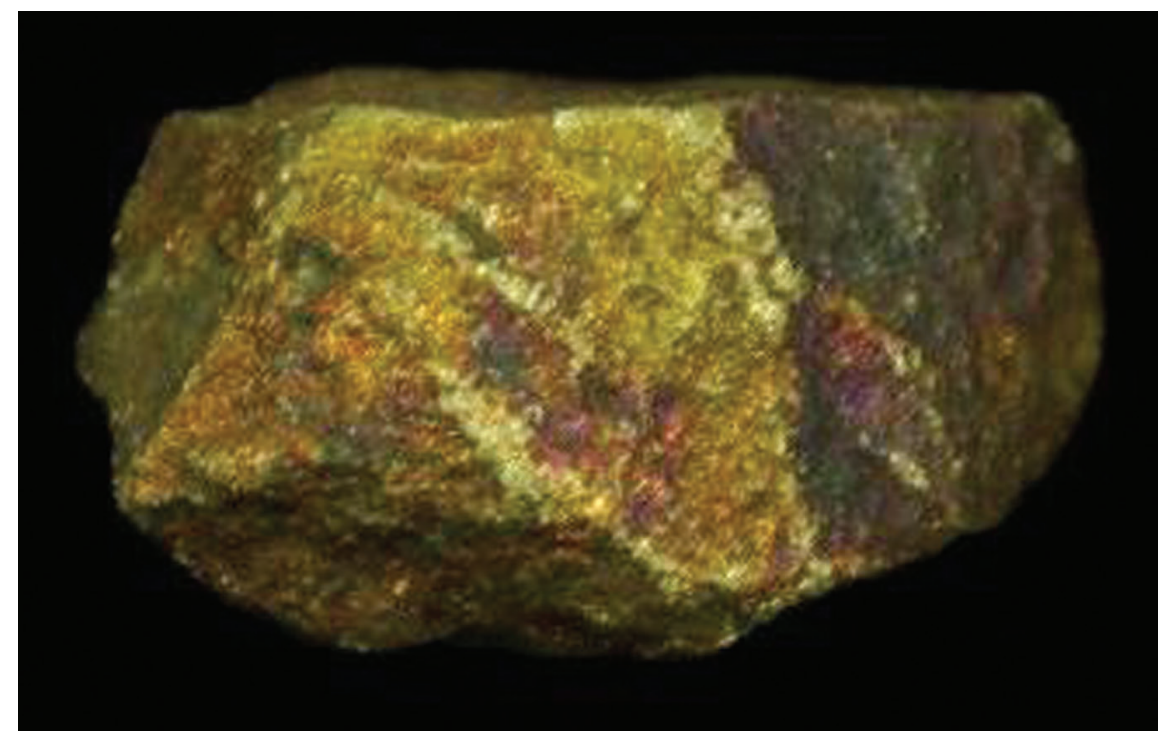

Chalcopyrite, Butte, Montana

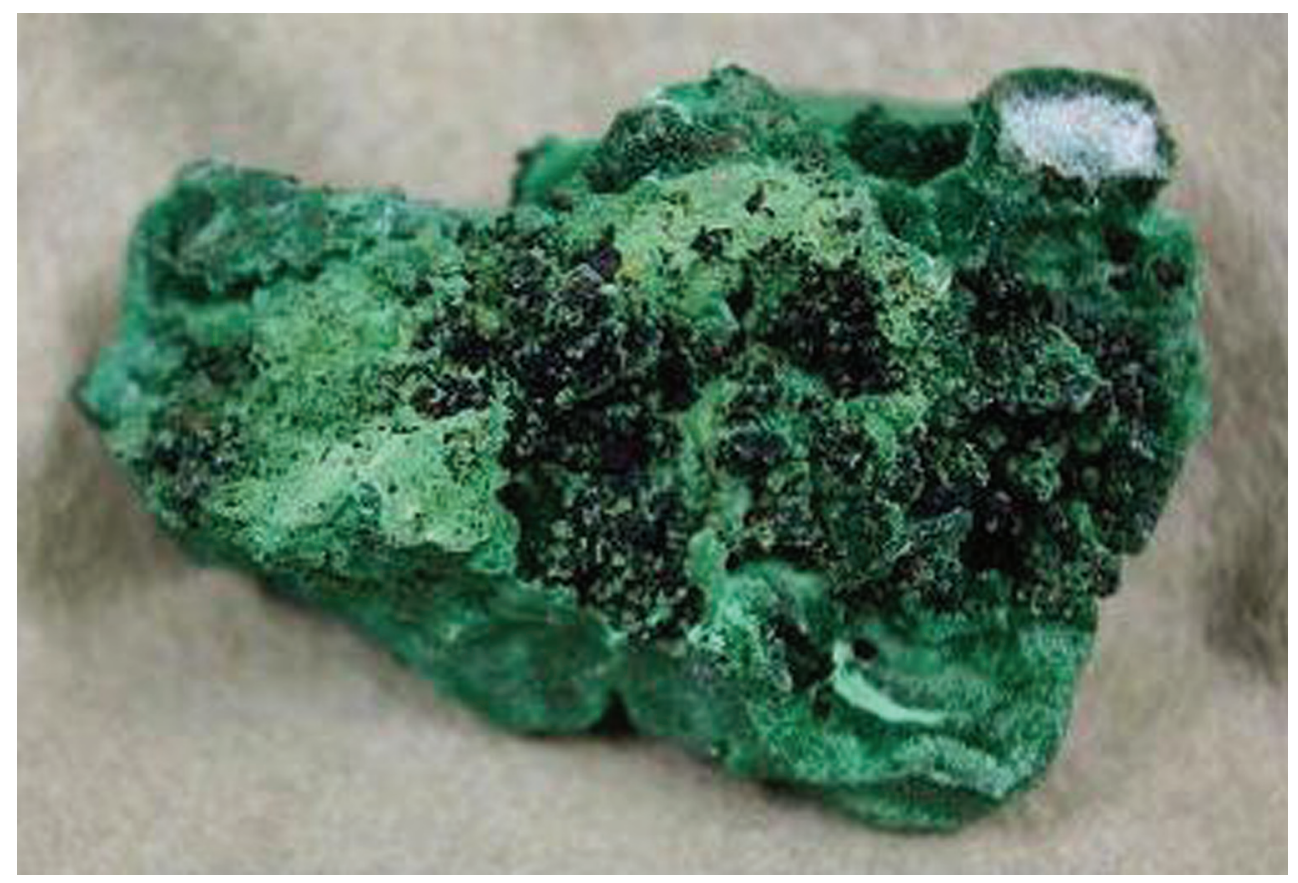

Malachite, Zaire, Africa 


\section{Appendix B}

\section{Scintag X-ray Diffractometer Instrument Set-Up and Scan Conditions Used to Collect Data}

The following instrument conditions were used to collect scan data :

- $\quad$ voltage $(\mathrm{kV})$

45

- $\quad$ current $(\mathrm{mA})$

35

- $\quad$ scan range $\left({ }^{\circ} 2 \theta\right)$

5 to $75^{\circ} 2 \theta$

- $\quad$ step

$0.02^{\circ} 2 \theta$

- $\quad$ seconds per step

5

- $\quad$ tube divergence slit

$2^{\circ}$

- $\quad$ tube scatter slit

$4^{\circ}$

- detector scatter slit

$0.5^{\circ}$

- detector reference slit

$0.2^{\circ}$

The Scintag X-ray diffractometer (XRD) was calibrated using National Institute of Standards and Technology Silicon x-ray Diffraction standard SRM 640. The calibration involves measuring the full width half maximum (FWHM) of the silicon standard over full scan range of the instrument, 0 to $90^{\circ} 2 \theta$ for the Scintag. The line broadening and goniometer aberrations are plotted to create a calibration curve specific to each instrument. The data-processing software described below uses this calibration to correct the measured sample scans.

In general, XRD has a detection limit of approximately 3 weight percent (wt\%). Highly crystalline minerals have a lower detection (approximately $1-3$ percent) limit and poorly crystalline minerals have a higher detection limit (approximately 3-5 percent). Amorphous materials do not produce unique reflections; however, they do contribute to the background intensity of the scan, which allows an estimate to be made of the total amorphous content.

\section{Data Processing}

First, the observed pattern, or data, is acquired from the XRD instrument. X-ray powder diffraction scans were reviewed for mineral phases present in each specimen. Mineral phases are identified in a scan by comparing observed reflections, both two-theta position and intensity, with reference standards. Mineral databases from the International Center for Diffraction Data (ICDD) and the National Institute of Standards and Technology Inorganic Crystal Structure Database (ICSD) were used to search for phases. Once all the reflections are assigned to mineral phases, the data was analyzed using Jade Whole Pattern Fit Analyses software (WPF v. 9.0.0). With the Jade software, whole pattern fitting of the observed data and Rietveld refinement of crystal structures are performed simultaneously (Young, 1995).

\section{Limitations of the data}

The WPF software normalizes the data to 100 percent for all identified phases. The typical detection limit by $\mathrm{X}$-ray diffraction is between 1 and $3 \mathrm{wt} \%$, depending on the crystallinity of the phase and interference from overlapping lines from other phases. Thus, there may be trace phases present, but not identified, and they are not included in the model. Furthermore, the amorphous content is calculated based on the internal standard. Any error introduced by grinding and blending that alters the weight ratio of the sample to internal standard will yield anomalous amorphous content, which in turn will be carried forward into the normalization and effect the mineral contents.

The WPF software calculates the unit cell for phases selected by the user. The unit cell (or lattice parameter) calculation produces the best results for major components because the XRD scan includes sufficient information (reflections and intensity). Minor and trace components having less intensity and often weak reflections do not show up in the scan. Lastly, as the number of phases increase in the sample, the line overlap (interference) increases, which reduces the accuracy of the unit-cell calculation. 


\section{Appendix C}

Appendix C. Bulk chemistry composition for four copper minerals.

[All by ICP-MS except mercury by CVAFS, and total carbon and total sulfur by LECO; na, not analyzed; \%, percent; ppm, parts per million; <, less than]

\begin{tabular}{|l|c|c|c|c|c|c|c|c|}
\hline \multicolumn{1}{|c|}{ Mineral } & $\mathbf{A g}$ & $\mathbf{A l}$ & $\mathbf{A s}$ & $\mathbf{B a}$ & $\mathbf{B e}$ & $\mathbf{B i}$ & $\mathbf{C O}_{2}$ & Carbonate C \\
\hline & $(\mathrm{ppm})$ & $(\mathrm{ppm})$ & $(\mathrm{ppm})$ & $(\mathrm{ppm})$ & $(\mathrm{ppm})$ & $(\mathrm{ppm})$ & $(\%)$ & $(\%)$ \\
\hline Azurite & 4.72 & 27300 & 47.5 & 14400 & 1.3 & $<0.06$ & 15.4 & 4.21 \\
\hline Chalcopyrite & 211 & 178 & 300 & 0.28 & 0.06 & 444 & na & na \\
\hline Bornite & 690 & 8670 & 13.5 & 179 & 0.24 & 404 & na & na \\
\hline Malachite & 0.723 & 168 & 4.9 & 6 & 1.7 & 2.24 & 19.3 & 5.26 \\
\hline
\end{tabular}

\begin{tabular}{|l|c|c|c|c|c|c|c|c|c|c|c|c|c|c|c|c|c|c|c|c|c|c|c|}
\hline \multicolumn{1}{|c}{ Mineral } & $\mathbf{C a}$ & $\mathbf{C d}$ & $\mathbf{C e}$ & $\mathbf{C o}$ & $\mathbf{C r}$ & $\mathbf{C s}$ & $\mathbf{C u}$ & $\mathbf{F e}$ & $\mathbf{H g}$ & $\mathbf{G a}$ & $\mathbf{K}$ & $\mathbf{L a}$ & $\mathbf{L i}$ & $\mathbf{M g}$ \\
\hline & $(\mathrm{ppm})$ & $(\mathrm{ppm})$ & $(\mathrm{ppm})$ & $(\mathrm{ppm})$ & $(\mathrm{ppm})$ & $(\mathrm{ppm})$ & $(\mathrm{ppm})$ & $(\mathrm{ppm})$ & $(\mathrm{ppm})$ & $(\mathrm{ppm})$ & $(\mathrm{ppm})$ & $(\mathrm{ppm})$ & $(\mathrm{ppm})$ & $(\mathrm{ppm})$ \\
\hline Azurite & 153 & 0.02 & 25.2 & 33.9 & 20.1 & 4.1 & 305000 & 2960 & 0.71 & 7.7 & 11300 & 14.2 & 21.9 & 3240 \\
\hline Chalcopyrite & 8900 & 15.3 & 0.3 & 2410 & $<0.5$ & 0.06 & 321000 & 266000 & 0.06 & 0.33 & $<20$ & 0.14 & $<0.3$ & 343 \\
\hline Bornite & 4210 & 416 & 15 & 14.8 & 1.6 & 2.4 & 430000 & 102000 & 0.06 & 3.6 & 9400 & 9.5 & $<0.3$ & 839 \\
\hline Malachite & $<100$ & 0.28 & 13.4 & 12400 & 4.9 & $<0.003$ & 534000 & 2260 & $<0.02$ & 1.8 & 48.2 & 9.6 & $<0.3$ & 124 \\
\hline
\end{tabular}

Results are preliminary.

\begin{tabular}{|l|c|c|c|c|c|c|c|c|c|c|c|c|}
\hline \multicolumn{1}{|c}{ Mineral } & $\mathbf{M n}$ & $\mathbf{M o}$ & $\mathbf{N a}$ & $\mathbf{N b}$ & $\mathbf{N i}$ & $\mathbf{P}$ & $\mathbf{P b}$ & $\mathbf{R b}$ & Total S & $\mathbf{S b}$ & $\mathbf{S c}$ & $\mathbf{S r}$ \\
\hline & $(\mathrm{ppm})$ & $(\mathrm{ppm})$ & $(\mathrm{ppm})$ & $(\mathrm{ppm})$ & $(\mathrm{ppm})$ & $(\mathrm{ppm})$ & $(\mathrm{ppm})$ & $(\mathrm{ppm})$ & $(\%)$ & $(\mathrm{ppm})$ & $(\mathrm{ppm})$ & $(\mathrm{ppm})$ \\
\hline Azurite & 12 & 2.9 & 519 & $<0.1$ & 6.6 & 96.4 & 29.7 & 60.6 & na & 3.6 & 5.5 & 13 \\
\hline Chalcopyrite & 129 & 3.8 & $<20$ & $<0.1$ & 71.1 & 79.8 & 442 & 0.04 & 27.6 & 2 & 0.09 & $<0.8$ \\
\hline Bornite & 78.6 & 4.5 & 424 & $<0.1$ & 5.7 & 180 & 9830 & 53.2 & 24.8 & 10 & 1.7 & 77.7 \\
\hline Malachite & 3190 & 24.8 & $<20$ & $<0.1$ & 6530 & 75.8 & 315 & 0.03 & na & $<0.04$ & 99.1 & $<0.8$ \\
\hline
\end{tabular}

\begin{tabular}{|l|c|c|c|c|c|c|c|}
\hline \multicolumn{1}{|c}{ Mineral } & Th & Ti & Tl & U & V & Y & Zn \\
\hline & $(p p m)$ & $(p p m)$ & $(p p m)$ & $(p p m)$ & $(p p m)$ & $(p p m)$ & $(p p m)$ \\
\hline Azurite & 6.43 & 1040 & 0.28 & 4.48 & 44.7 & 13.4 & 31.5 \\
\hline Chalcopyrite & 0.12 & $<40$ & $<0.08$ & 0.36 & 1.3 & 0.3 & 934 \\
\hline Bornite & 0.72 & 380 & 1.38 & 10.8 & 33.9 & 40.6 & 45900 \\
\hline Malachite & $<0.1$ & $<40$ & 0.13 & 374 & 9.2 & 41.6 & 41 \\
\hline
\end{tabular}




\section{Appendix D}

Appendix D. Leachate chemical composition of four copper mineral samples.

[Leaching procedures used for this study were the USGS FLT, U.S. Geological Survey Field Leach Test; USEPA, U.S. Environmental Protection Agency (SPLP), Synthetic Precipitation Leaching Procedure leachate $\mathrm{pH}$ of 4.2 and 5.0; and USEPA (TCLP) Toxicity Characteristic Leaching Procedure]. All data produced using ICP-MS except $\mathrm{pH}$ and specific conductance (hand-held meters), and mercury (CVAFS); na $=$ not analyzed; $<=$ less than; $\mathrm{mg} / \mathrm{L}=\mathrm{milligrams} \mathrm{per} \mathrm{liter;}$ $\mu \mathrm{g} / \mathrm{L}=$ micrograms per liter; $\mathrm{ng} / \mathrm{L}=$ nanograms per liter; $\mu \mathrm{s} / \mathrm{cm}$, microsecond per centimeter; Std, standard]

\begin{tabular}{|c|c|c|c|c|c|c|c|c|c|}
\hline Leach test & Mineral & $\begin{array}{c}\text { pH } \\
\text { (Std. units) }\end{array}$ & $\begin{array}{c}\text { Conductivity } \\
(\mu \mathrm{S} / \mathrm{cm})\end{array}$ & $\begin{array}{c}\mathbf{A g} \\
(\mu \mathrm{g} / \mathrm{L})\end{array}$ & $\begin{array}{c}\text { Al } \\
(\mu \mathrm{g} / \mathrm{L})\end{array}$ & $\begin{array}{c}\text { As } \\
(\mu \mathrm{g} / \mathrm{L})\end{array}$ & $\begin{array}{c}\mathrm{Ba} \\
(\mu \mathrm{g} / \mathrm{L})\end{array}$ & $\begin{array}{c}\mathrm{Be} \\
(\mu \mathrm{g} / \mathrm{L})\end{array}$ & $\begin{array}{c}\mathbf{B i} \\
(\mu \mathrm{g} / \mathrm{L})\end{array}$ \\
\hline USGS FLT & Azurite & 9.1 & 35 & $<1$ & 185 & 2 & 8.52 & $<0.05$ & $<0.2$ \\
\hline USGS FLT & Chalcopyrite & 5.9 & 10.20 & $<1$ & $<2$ & $<1$ & 216 & $<0.05$ & $<0.2$ \\
\hline USGS FLT & Bornite & 8.2 & 8.30 & $<1$ & 5.1 & $<1$ & 268 & $<0.05$ & $<0.2$ \\
\hline USGS FLT & Malachite & 8.1 & 9.50 & $<1$ & 2.1 & $<1$ & 240 & $<0.05$ & $<0.2$ \\
\hline USEPA SPLP pH 4.2 & Azurite & 7.6 & 56.0 & $<1$ & 4.6 & $<1$ & 186 & $<0.05$ & $<0.2$ \\
\hline USEPA SPLP pH 4.2 & Chalcopyrite & 5.2 & 23.0 & $<1$ & $<2$ & 3 & 142 & $<0.05$ & $<0.2$ \\
\hline USEPA SPLP pH 4.2 & Bornite & 9.0 & 44.0 & $<1$ & 58.5 & $<1$ & 128 & $<0.05$ & $<0.2$ \\
\hline USEPA SPLP pH 4.2 & Malachite & 7.5 & 23.0 & $<1$ & $<2$ & $<1$ & 245 & $<0.05$ & $<0.2$ \\
\hline USEPA SPLP pH 5.0 & Azurite & 7.3 & 53.0 & $<1$ & $<2$ & $<1$ & 693 & $<0.05$ & $<0.2$ \\
\hline USEPA SPLP pH 5.0 & Chalcopyrite & 5.5 & 20.00 & $<1$ & $<2$ & $<1$ & 115 & $<0.05$ & $<0.2$ \\
\hline USEPA SPLP pH 5.0 & Bornite & 9.3 & 44.0 & $<1$ & 50.2 & $<1$ & 144 & $<0.05$ & $<0.2$ \\
\hline USEPA SPLP pH 5.0 & Malachite & 7.2 & 12.0 & $<1$ & $<2$ & $<1$ & 204 & $<0.05$ & $<0.2$ \\
\hline USEPA TCLP & Azurite & 4.9 & 4400 & $<1$ & 200 & 7 & 2100 & 0.5 & $<0.2$ \\
\hline USEPA TCLP & Chalcopyrite & 4.7 & 4200 & $<1$ & 89.7 & 3.2 & 431 & 0.05 & 8.03 \\
\hline USEPA TCLP & Bornite & 4.8 & 4300 & $<1$ & 227 & $<1$ & 402 & 0.3 & 10.3 \\
\hline USEPA TCLP & Malachite & 5.0 & 4400 & $<1$ & 11.3 & 1 & 341 & 2.1 & $<0.2$ \\
\hline
\end{tabular}

\begin{tabular}{|c|c|c|c|c|c|c|c|c|c|}
\hline Leach test & Mineral & $\begin{array}{c}\mathbf{C a} \\
(\mathrm{mg} / \mathrm{L}) \\
\end{array}$ & $\begin{array}{c}\mathbf{C d} \\
(\mu \mathrm{g} / \mathrm{L}) \\
\end{array}$ & $\begin{array}{c}\mathrm{Ce} \\
(\mu \mathrm{g} / \mathrm{L}) \\
\end{array}$ & $\begin{array}{c}\text { Co } \\
(\mu \mathrm{g} / \mathrm{L}) \\
\end{array}$ & $\begin{array}{c}\mathbf{C r} \\
(\mu \mathrm{g} / \mathrm{L}) \\
\end{array}$ & $\begin{array}{c}\text { Cs } \\
(\mu \mathrm{g} / \mathrm{L}) \\
\end{array}$ & $\begin{array}{c}\mathrm{Cu} \\
(\mu \mathrm{g} / \mathrm{L})\end{array}$ & $\begin{array}{c}\text { Dy } \\
(\mu \mathrm{g} / \mathrm{L})\end{array}$ \\
\hline USGS FLT & Azurite & $<0.2$ & $<0.02$ & 0.02 & 0.23 & 1.3 & 0.08 & 178 & 0.04 \\
\hline USGS FLT & Chalcopyrite & 0.76 & 3.49 & $<0.01$ & 12.1 & $<1$ & 0.02 & 12 & $<0.005$ \\
\hline USGS FLT & Bornite & 1.4 & 0.03 & $<0.01$ & 0.35 & 1.2 & $<0.02$ & 8.3 & 0.01 \\
\hline USGS FLT & Malachite & 0.47 & $<0.02$ & $<0.01$ & 4.3 & 3.1 & $<0.02$ & 104 & $<0.005$ \\
\hline USEPA SPLP pH 4.2 & Azurite & 0.79 & 0.29 & 0.01 & 1.1 & 1.1 & $<0.02$ & 0.88 & $<0.005$ \\
\hline USEPA SPLP pH 4.2 & Chalcopyrite & 1.48 & 7.38 & $<0.01$ & 31.7 & 1 & 0.07 & 5.9 & $<0.005$ \\
\hline USEPA SPLP pH 4.2 & Bornite & 6.62 & 0.09 & $<0.01$ & 0.14 & $<1$ & $<0.02$ & 3.7 & $<0.005$ \\
\hline USEPA SPLP pH 4.2 & Malachite & 0.8 & $<0.02$ & $<0.01$ & 368 & 4.5 & $<0.02$ & 183 & $<0.005$ \\
\hline USEPA SPLP pH 5.0 & Azurite & 0.56 & $<0.02$ & $<0.01$ & 0.68 & 1.4 & $<0.02$ & 171 & $<0.005$ \\
\hline USEPA SPLP pH 5.0 & Chalcopyrite & 1.63 & 4.08 & $<0.01$ & 28.6 & 1.6 & 0.05 & 2.6 & $<0.005$ \\
\hline USEPA SPLP pH 5.0 & Bornite & 7.45 & $<0.02$ & $<0.01$ & 0.03 & 1.1 & 0.03 & 5.8 & $<0.005$ \\
\hline USEPA SPLP pH 5.0 & Malachite & 0.61 & $<0.02$ & $<0.01$ & 207 & 2.1 & $<0.02$ & 91.7 & $<0.005$ \\
\hline USEPA TCLP & Azurite & 1.53 & 0.07 & 0.8 & 8.58 & 6.8 & 0.16 & 194000 & 0.78 \\
\hline USEPA TCLP & Chalcopyrite & 1.76 & 9.48 & 0.04 & 27 & 10.6 & 1.47 & 545 & 0.01 \\
\hline USEPA TCLP & Bornite & 24.4 & 6.31 & 0.55 & 10.7 & 11.5 & 23.5 & 19700 & 0.67 \\
\hline USEPA TCLP & Malachite & 0.56 & 0.12 & 9.8 & 1700 & 9.1 & $<0.02$ & 173000 & 43.8 \\
\hline
\end{tabular}


Appendix D. Leachate chemical composition of four copper mineral samples.-Continued

[Leaching procedures used for this study were the USGS FLT, U.S. Geological Survey Field Leach Test; USEPA, U.S. Environmental Protection Agency (SPLP), Synthetic Precipitation Leaching Procedure leachate $\mathrm{pH}$ of 4.2 and 5.0; and USEPA (TCLP) Toxicity Characteristic Leaching Procedure]. All data produced using ICP-MS except $\mathrm{pH}$ and specific conductance (hand-held meters), and mercury (CVAFS); na = not analyzed; $<=$ less than; $\mathrm{mg} / \mathrm{L}=\mathrm{milligrams}$ per liter; $\mu \mathrm{g} / \mathrm{L}=$ micrograms per liter; $\mathrm{ng} / \mathrm{L}=$ nanograms per liter; $\mu \mathrm{s} / \mathrm{cm}$, microsecond per centimeter; Std, standard]

\begin{tabular}{|c|c|c|c|c|c|c|c|c|c|c|}
\hline Leach test & Mineral & $\begin{array}{c}\mathrm{Er} \\
(\mu \mathrm{g} / \mathrm{L})\end{array}$ & $\begin{array}{c}\text { Eu } \\
(\mu \mathrm{g} / \mathrm{L})\end{array}$ & $\begin{array}{c}\mathrm{Fe} \\
(\mu \mathrm{g} / \mathrm{L}) \\
\end{array}$ & $\begin{array}{c}\text { Ga } \\
(\mu \mathrm{g} / \mathrm{L}) \\
\end{array}$ & $\begin{array}{c}\text { Gd } \\
(\mu \mathrm{g} / \mathrm{L})\end{array}$ & $\begin{array}{c}\text { Ge } \\
(\mu \mathrm{g} / \mathrm{L})\end{array}$ & $\begin{array}{c}\mathrm{Hg} \\
(\mathrm{ng} / \mathrm{L})\end{array}$ & $\begin{array}{c}\text { Ho } \\
(\mu \mathrm{g} / \mathrm{L})\end{array}$ & $\begin{array}{c}\mathrm{K} \\
(\mathrm{mg} / \mathrm{L}) \\
\end{array}$ \\
\hline USGS FLT & Azurite & 0.03 & $<0.005$ & $<50$ & 0.07 & 0.02 & $<0.05$ & 280 & 0.01 & 0.41 \\
\hline USG & Chalcopyrite & $<0.005$ & 0.02 & $<50$ & $<0.05$ & $<0.005$ & $<0.05$ & $<5$ & $<0.005$ & 0.1 \\
\hline USG & Bornite & $<0.005$ & 0.02 & $<50$ & $<0.05$ & $<0.005$ & $<0.05$ & $<5$ & $<0.005$ & 0.1 \\
\hline USGS FLT & Malachite & $<0.005$ & 0.02 & $<50$ & $<0.05$ & $<0.005$ & $<0.05$ & 10 & $<0.005$ & 0.68 \\
\hline USEPA SPLP & Azurite & $<0.005$ & 0.02 & $<50$ & $<0.05$ & $<0.005$ & $<0.05$ & 290 & $<0.005$ & 0.1 \\
\hline USEPA SPLP pH 4.2 & Chalcopyrite & $<0.005$ & 0.01 & 1040 & $<0.05$ & $<0.005$ & $<0.05$ & $<5$ & $<0.005$ & 0.2 \\
\hline USEPA SPLP pH 4.2 & Bornite & $<0.005$ & 0.01 & $<50$ & 0.25 & $<0.005$ & $<0.05$ & $<5$ & $<0.005$ & 0.07 \\
\hline USEPA SPLP pH 4.2 & Malachite & $<0.005$ & 0.02 & $<50$ & $<0.05$ & $<0.005$ & $<0.05$ & 16 & $<0.005$ & 2.12 \\
\hline USEPA SPLP $p$ & Azurite & $<0.005$ & 0.06 & $<50$ & $<0.05$ & $<0.005$ & $<0.05$ & 300 & $<0.005$ & 1.2 \\
\hline USEPA SPLP pH 5.0 & Chalcopyrite & $<0.005$ & 0.01 & 681 & $<0.05$ & $<0.005$ & $<0.05$ & $<5$ & $<0.005$ & 0.2 \\
\hline USEPA SPLP pH 5.0 & Bornite & $<0.005$ & 0.01 & $<50$ & 0.24 & $<0.005$ & $<0.05$ & $<5$ & $<0.005$ & 0.1 \\
\hline USEPA SPLP pH 5.0 & Malachite & $<0.005$ & 0.02 & $<50$ & $<0.05$ & $<0.005$ & $<0.05$ & 6 & $<0.005$ & 0.81 \\
\hline USEPA TCLP & Azurite & 0.57 & 0.45 & $<50$ & $<0.05$ & 0.73 & $<0.05$ & 700 & 0.18 & 2.4 \\
\hline USEPA TCLP & Chalcopyrite & 0.005 & 0.05 & 1520 & $<0.05$ & 0.007 & $<0.05$ & 16 & $<0.005$ & 2.12 \\
\hline USEPA TCLP & Bornite & 0.42 & 0.14 & 1390 & $<0.05$ & 0.63 & $<0.05$ & $<5$ & 0.14 & 2.18 \\
\hline USEPA TCLP & Malachite & 21.3 & 18.5 & $<50$ & 0.42 & 47.6 & 0.28 & 73 & 7.56 & 2.55 \\
\hline
\end{tabular}

\begin{tabular}{|c|c|c|c|c|c|c|c|c|c|c|c|}
\hline Leach test & Mineral & $\begin{array}{c}\text { La } \\
(\mu \mathrm{g} / \mathrm{L})\end{array}$ & $\begin{array}{c}\mathrm{Li} \\
(\mu \mathrm{g} / \mathrm{L})\end{array}$ & $\begin{array}{c}\text { Lu } \\
(\mu \mathrm{g} / \mathrm{L})\end{array}$ & $\begin{array}{c}\mathrm{Mg} \\
(\mathrm{mg} / \mathrm{L})\end{array}$ & $\begin{array}{c}\text { Mn } \\
(\mu \mathrm{g} / \mathrm{L})\end{array}$ & $\begin{array}{c}\text { Mo } \\
(\mu \mathrm{g} / \mathrm{L}) \\
\end{array}$ & $\begin{array}{c}\mathrm{Na} \\
\mathrm{mg} / \mathrm{L}\end{array}$ & $\begin{array}{c}\mathbf{N b} \\
(\mu \mathrm{g} / \mathrm{L})\end{array}$ & $\begin{array}{c}\text { Nd } \\
(\mu \mathrm{g} / \mathrm{L})\end{array}$ & $\begin{array}{c}\mathbf{N i} \\
(\mu \mathrm{g} / \mathrm{L})\end{array}$ \\
\hline USGS FLT & Azurite & $<0.01$ & $<0.1$ & $<0.1$ & 0.02 & $<0.2$ & $<2$ & 6.32 & $<0.2$ & 0.01 & $<0.4$ \\
\hline USGS FLT & Chalcopyrite & $<0.01$ & 5 & $<0.1$ & 0.08 & 28.3 & $<2$ & 2.13 & $<0.2$ & $<0.01$ & 1.7 \\
\hline USGS FLT & Bornite & $<0.01$ & $<0.1$ & $<0.1$ & 0.09 & 2.8 & $<2$ & 2.43 & $<0.2$ & $<0.01$ & 0.4 \\
\hline USGS FLT & Malachite & $<0.01$ & $<0.1$ & $<0.1$ & 0.05 & 0.6 & $<2$ & 2.2 & $<0.2$ & $<0.01$ & 5.4 \\
\hline USEPA SPLP pH 4.2 & Azurite & 0.01 & $<0.1$ & $<0.1$ & 0.22 & 2.1 & $<2$ & 2.45 & $<0.2$ & $<0.01$ & 1.1 \\
\hline USEPA SPLP pH 4.2 & Chalcopyrite & $<0.01$ & 6.7 & $<0.1$ & 0.1 & 70.3 & $<2$ & 1.67 & $<0.2$ & $<0.01$ & 4.3 \\
\hline USEPA SPLP pH 4.2 & Bornite & $<0.01$ & 0.3 & $<0.1$ & 0.16 & 6.2 & $<2$ & 1.44 & $<0.2$ & $<0.01$ & $<0.4$ \\
\hline USEPA SPLP pH 4.2 & Malachite & $<0.01$ & 0.3 & $<0.1$ & 0.12 & 3.6 & $<2$ & 2.93 & $<0.2$ & $<0.01$ & 560 \\
\hline USEPA SPLP pH & Azurite & $<0.01$ & 0.3 & $<0.1$ & 0.1 & 0.8 & $<2$ & 9.75 & $<0.2$ & $<0.01$ & $<0.4$ \\
\hline USEPA SPLP pH 5.0 & Chalcopyrite & $<0.01$ & 6.1 & $<0.1$ & 0.11 & 56.6 & $<2$ & 1.59 & $<0.2$ & $<0.01$ & 2.8 \\
\hline USEPA SPLP pH 5.0 & Bornite & $<0.01$ & 0.5 & $<0.1$ & 0.15 & 1.2 & $<2$ & 1.78 & $<0.2$ & $<0.01$ & $<0.4$ \\
\hline USEPA SPLP pH 5.0 & Malachite & $<0.01$ & $<0.1$ & $<0.1$ & 0.08 & 2.4 & $<2$ & 2.26 & $<0.2$ & $<0.01$ & 318 \\
\hline USEPA TCLP & Azurite & 0.33 & $<0.1$ & $<0.1$ & 0.52 & 12.3 & $<2$ & $\mathrm{nr}$ & $<0.2$ & 0.94 & 1.8 \\
\hline USEPA TCLP & Chalcopyrite & 0.03 & 3 & $<0.1$ & 0.14 & 56.8 & $<2$ & $\mathrm{nr}$ & $<0.2$ & 0.03 & 4.4 \\
\hline USEPA TCLP & Bornite & 0.26 & $<0.1$ & $<0.1$ & 0.38 & 240 & $<2$ & $\mathrm{nr}$ & $<0.2$ & 0.61 & 5.6 \\
\hline USEPA TCLP & Malachite & 24.8 & $<0.1$ & 2.8 & 0.19 & 467 & $<2$ & $\mathrm{nr}$ & $<0.2$ & 187 & 1650 \\
\hline
\end{tabular}


Appendix D. Leachate chemical composition of four copper mineral samples.-Continued

[Leaching procedures used for this study were the USGS FLT, U.S. Geological Survey Field Leach Test; USEPA, U.S. Environmental Protection Agency (SPLP), Synthetic Precipitation Leaching Procedure leachate $\mathrm{pH}$ of 4.2 and 5.0; and USEPA (TCLP) Toxicity Characteristic Leaching Procedure]. All data produced using ICP-MS except $\mathrm{pH}$ and specific conductance (hand-held meters), and mercury (CVAFS); na $=$ not analyzed; $<=$ less than; $\mathrm{mg} / \mathrm{L}=\mathrm{milligrams}$ per liter; $\mu \mathrm{g} / \mathrm{L}=$ micrograms per liter; $\mathrm{ng} / \mathrm{L}=$ nanograms per liter; $\mu \mathrm{s} / \mathrm{cm}$, microsecond per centimeter; Std, standard]

\begin{tabular}{|c|c|c|c|c|c|c|c|c|c|c|}
\hline Leach test & Mineral & $\begin{array}{c}\mathbf{P} \\
(\mathrm{mg} / \mathrm{L}) \\
\end{array}$ & $\begin{array}{c}\mathbf{P b} \\
(\mu \mathrm{g} / \mathrm{L}) \\
\end{array}$ & $\begin{array}{c}\mathrm{Pr} \\
(\mu \mathrm{g} / \mathrm{L}) \\
\end{array}$ & $\begin{array}{c}\mathbf{R b} \\
(\mu \mathrm{g} / \mathrm{L}) \\
\end{array}$ & $\begin{array}{c}\text { Sb } \\
(\mu \mathrm{g} / \mathrm{L}) \\
\end{array}$ & $\begin{array}{c}\text { Sc } \\
(\mu \mathrm{g} / \mathrm{L}) \\
\end{array}$ & $\begin{array}{c}\mathrm{Se} \\
(\mu \mathrm{g} / \mathrm{L}) \\
\end{array}$ & $\begin{array}{c}\mathrm{SiO}_{2} \\
(\mathrm{mg} / \mathrm{L}) \\
\end{array}$ & $\begin{array}{c}\mathrm{Sm} \\
(\mu \mathrm{g} / \mathrm{L}) \\
\end{array}$ \\
\hline USGS FLT & Azurite & 0.05 & 0.09 & $<0.01$ & 0.46 & $<0.3$ & $<0.6$ & $<1$ & 0.8 & $<0.01$ \\
\hline USGS FLT & Chalcopyrite & 0.1 & 0.3 & $<0.01$ & 0.06 & $<0.3$ & $<0.6$ & $<1$ & $<0.2$ & $<0.01$ \\
\hline USGS FLT & Bornite & 0.06 & 0.78 & $<0.01$ & 0.04 & $<0.3$ & $<0.6$ & $<1$ & $<0.2$ & $<0.01$ \\
\hline USGS FLT & Malachite & 0.03 & $<0.05$ & $<0.01$ & 0.14 & $<0.3$ & $<0.6$ & $<1$ & $<0.2$ & $<0.01$ \\
\hline USEPA SPLP pH 4.2 & Azurite & $<0.01$ & 2710 & $<0.01$ & 0.05 & 4.88 & $<0.6$ & $<1$ & 0.4 & $<0.01$ \\
\hline USEPA SPLP pH 4.2 & Chalcopyrite & 0.2 & 0.2 & $<0.01$ & 0.16 & 1.79 & $<0.6$ & $<1$ & 0.4 & $<0.01$ \\
\hline USEPA SPLP pH 4.2 & Bornite & 0.04 & 0.3 & $<0.01$ & 0.05 & 0.75 & $<0.6$ & $<1$ & 0.4 & $<0.01$ \\
\hline USEPA SPLP pH 4.2 & Malachite & $<0.01$ & 0.06 & $<0.01$ & 0.67 & $<0.3$ & $<0.6$ & $<1$ & 2.2 & $<0.01$ \\
\hline USEPA SPLP pH 5.0 & Azurite & $<0.01$ & 0.2 & $<0.01$ & 0.45 & $<0.3$ & $<0.6$ & $<1$ & 1.6 & $<0.01$ \\
\hline USEPA SPLP pH 5.0 & Chalcopyrite & $<0.01$ & 0.2 & $<0.01$ & 0.13 & 1.33 & $<0.6$ & $<1$ & $<0.2$ & $<0.01$ \\
\hline USEPA SPLP pH 5.0 & Bornite & $<0.01$ & 0.2 & $<0.01$ & 0.1 & 0.54 & $<0.6$ & $<1$ & 0.2 & $<0.01$ \\
\hline USEPA SPLP pH 5.0 & Malachite & $<0.01$ & 0.09 & $<0.01$ & 0.22 & $<0.3$ & $<0.6$ & $<1$ & 0.7 & $<0.01$ \\
\hline USEPA TCLP & Azurite & $<0.01$ & 6 & 0.14 & 1.35 & $<0.3$ & $<0.6$ & $<1$ & 2.6 & 0.33 \\
\hline USEPA TCLP & Chalcopyrite & 0.2 & 115 & $<0.01$ & 1.74 & 4.67 & $<0.6$ & $<1$ & 2 & 0.01 \\
\hline USEPA TCLP & Bornite & $<0.01$ & 990 & 0.1 & 11.8 & 5.82 & 1 & $<1$ & 2.3 & 0.35 \\
\hline USEPA TCLP & Malachite & $<0.01$ & 383 & 33.7 & 1.26 & $<0.3$ & 5.9 & $<1$ & 2 & 62.6 \\
\hline
\end{tabular}

\begin{tabular}{|c|c|c|c|c|c|c|c|c|c|c|}
\hline Leach test & Mineral & $\begin{array}{c}\mathrm{SO}_{4} \\
(\mathrm{mg} / \mathrm{L}) \\
\end{array}$ & $\begin{array}{c}\text { Sr } \\
(\mu \mathrm{g} / \mathrm{L}) \\
\end{array}$ & $\begin{array}{c}\text { Ta } \\
(\mu \mathrm{g} / \mathrm{L}) \\
\end{array}$ & $\begin{array}{c}\text { Tb } \\
(\mu \mathrm{g} / \mathrm{L})\end{array}$ & $\begin{array}{c}\text { Th } \\
(\mu \mathrm{g} / \mathrm{L})\end{array}$ & $\begin{array}{c}\mathrm{Ti} \\
(\mu \mathrm{g} / \mathrm{L}) \\
\end{array}$ & $\begin{array}{c}\text { TI } \\
(\mu \mathrm{g} / \mathrm{L}) \\
\end{array}$ & $\begin{array}{c}\mathrm{Tm} \\
(\mu \mathrm{g} / \mathrm{L})\end{array}$ & $\begin{array}{c}\mathbf{U} \\
(\mu \mathrm{g} / \mathrm{L}) \\
\end{array}$ \\
\hline USGS FLT & Azurite & $<2$ & $<0.5$ & $<0.02$ & $<0.005$ & $<0.2$ & 1 & $<0.1$ & $<0.005$ & 0.1 \\
\hline USG & Chalcopyrite & 6 & 7.74 & $<0.02$ & $<0.005$ & $<0.2$ & $<0.5$ & $<0.1$ & $<0.005$ & $<0.1$ \\
\hline USGS FLT & Bornite & 6 & 10.8 & $<0.02$ & $<0.005$ & $<0.2$ & $<0.5$ & $<0.1$ & $<0.005$ & $<0.1$ \\
\hline USG & Malachite & 4 & 6.43 & $<0.02$ & $<0.005$ & $<0.2$ & $<0.5$ & $<0.1$ & $<0.005$ & $<0.1$ \\
\hline USEI & Azurite & 7 & 7.49 & $<0.02$ & $<0.005$ & $<0.2$ & $<0.5$ & $<0.1$ & $<0.005$ & $<0.1$ \\
\hline USEPA SPLP pH 4.2 & Chalcopyrite & 8 & 6.13 & $<0.02$ & $<0.005$ & $<0.2$ & $<0.5$ & $<0.1$ & $<0.005$ & $<0.1$ \\
\hline USEPA SPLP pH 4.2 & Bornite & 9 & 12.6 & $<0.02$ & $<0.005$ & $<0.2$ & $<0.5$ & $<0.1$ & $<0.005$ & $<0.1$ \\
\hline USEPA SPLP pH 4.2 & Malachite & 7 & 7.35 & $<0.02$ & $<0.005$ & $<0.2$ & $<0.5$ & $<0.1$ & $<0.005$ & $<0.1$ \\
\hline USEPA SPLP pH 5.0 & Azurite & 9 & 5.97 & $<0.02$ & $<0.005$ & $<0.2$ & $<0.5$ & $<0.1$ & $<0.005$ & $<0.1$ \\
\hline USEPA SPLP pH 5.0 & Chalcopyrite & 9 & 6.02 & $<0.02$ & $<0.005$ & $<0.2$ & $<0.5$ & $<0.1$ & $<0.005$ & $<0.1$ \\
\hline USEPA SPLP pH 5.0 & Bornite & 12 & 16.2 & $<0.02$ & $<0.005$ & $<0.2$ & $<0.5$ & $<0.1$ & $<0.005$ & $<0.1$ \\
\hline USEPA SPLP pH 5.0 & Malachite & 6 & 6.58 & $<0.02$ & $<0.005$ & $<0.2$ & $<0.5$ & $<0.1$ & $<0.005$ & $<0.1$ \\
\hline USEPA TCLP & Azurite & 3 & 35.9 & $<0.02$ & 0.11 & $<0.2$ & $<0.5$ & $<0.1$ & 0.075 & 1.64 \\
\hline USEPA TCLP & Chalcopyrite & 5 & 40 & $<0.02$ & $<0.005$ & $<0.2$ & $<0.5$ & 0.3 & $<0.005$ & 0.17 \\
\hline USEPA TCLP & Bornite & 5 & 69.5 & $<0.02$ & 0.1 & $<0.2$ & $<0.5$ & 0.87 & 0.065 & 2.68 \\
\hline USEPA TCLP & Malachite & $<2$ & 24.9 & $<0.02$ & 7.67 & $<0.2$ & $<0.5$ & 0.2 & 3.05 & 1300 \\
\hline
\end{tabular}


Appendix D. Leachate chemical composition of four copper mineral samples.-Continued

[Leaching procedures used for this study were the USGS FLT, U.S. Geological Survey Field Leach Test; USEPA, U.S. Environmental Protection Agency (SPLP), Synthetic Precipitation Leaching Procedure leachate $\mathrm{pH}$ of 4.2 and 5.0; and USEPA (TCLP) Toxicity Characteristic Leaching Procedure]. All data produced using ICP-MS except $\mathrm{pH}$ and specific conductance (hand-held meters), and mercury (CVAFS); na $=$ not analyzed; $<=$ less than; $\mathrm{mg} / \mathrm{L}=$ milligrams per liter; $\mu \mathrm{g} / \mathrm{L}=$ micrograms per liter; $\mathrm{ng} / \mathrm{L}=$ nanograms per liter; $\mu \mathrm{s} / \mathrm{cm}$, microsecond per centimeter; Std, standard]

\begin{tabular}{|l|c|c|c|c|c|c|c|}
\hline Leach test & Mineral & $\mathbf{V}$ & $\mathbf{W}$ & $\mathbf{Y}$ & $\mathbf{Y b}$ & $\mathbf{Z n}$ & $\mathbf{Z r}$ \\
\hline & & $(\mu \mathrm{g} / \mathrm{L})$ & $(\mu \mathrm{g} / \mathrm{L})$ & $(\mu \mathrm{g} / \mathrm{L})$ & $(\mu \mathrm{g} / \mathrm{L})$ & $(\mu \mathrm{g} / \mathrm{L})$ & $(\mu \mathrm{g} / \mathrm{L})$ \\
\hline USGS FLT & Azurite & 1.6 & $<0.5$ & 0.27 & 0.04 & 1.1 & 1.2 \\
\hline USGS FLT & Chalcopyrite & $<0.5$ & $<0.5$ & $<0.01$ & $<0.005$ & 227 & $<0.2$ \\
\hline USGS FLT & Bornite & 0.5 & $<0.5$ & 0.02 & $<0.005$ & 46.4 & $<0.2$ \\
\hline USGS FLT & Malachite & $<0.5$ & $<0.5$ & $<0.01$ & $<0.005$ & 49.5 & $<0.2$ \\
\hline & & & & & & & \\
\hline USEPA SPLP pH 4.2 & Azurite & $<0.5$ & $<0.5$ & $<0.01$ & $<0.005$ & 278 & $<0.2$ \\
\hline USEPA SPLP pH 4.2 & Chalcopyrite & $<0.5$ & $<0.5$ & $<0.01$ & $<0.005$ & 396 & $<0.2$ \\
\hline USEPA SPLP pH 4.2 & Bornite & $<0.5$ & $<0.5$ & $<0.01$ & $<0.005$ & 31 & $<0.2$ \\
\hline USEPA SPLP pH 4.2 & Malachite & 0.7 & $<0.5$ & $<0.01$ & $<0.005$ & 163 & $<0.2$ \\
\hline & & & & & & & \\
\hline USEPA SPLP pH 5.0 & Azurite & $<0.5$ & $<0.5$ & $<0.01$ & $<0.005$ & 133 & $<0.2$ \\
\hline USEPA SPLP pH 5.0 & Chalcopyrite & $<0.5$ & $<0.5$ & $<0.01$ & $<0.005$ & 255 & $<0.2$ \\
\hline USEPA SPLP pH 5.0 & Bornite & $<0.5$ & $<0.5$ & $<0.01$ & $<0.005$ & 33.2 & $<0.2$ \\
\hline USEPA SPLP pH 5.0 & Malachite & $<0.5$ & $<0.5$ & $<0.01$ & $<0.005$ & 116 & $<0.2$ \\
\hline & & & & & & & \\
\hline USEPA TCLP & Azurite & 2 & $<0.5$ & 6.53 & 0.5 & 172 & $<0.2$ \\
\hline USEPA TCLP & Chalcopyrite & 2.7 & $<0.5$ & 0.07 & 0.005 & 381 & $<0.2$ \\
\hline USEPA TCLP & Bornite & 2.8 & $<0.5$ & 4.25 & 0.54 & 452 & $<0.2$ \\
\hline USEPA TCLP & Malachite & 1.6 & $<0.5$ & 25.5 & 22 & 105 & $<0.2$ \\
\hline
\end{tabular}




\section{Appendix E}

Appendix E. Leachate concentrations as milligrams leached per kilograms solid for measured elements by mineral, and as measured in simulated gastric fluid (SGF) simulated intestinal fluid (SIF), simulated lung fluid (SLF), simulated phagolysosomal fluid (SPF), and cell carrier fluid (CCF).

${ }^{*}$, blank correction resulted in a negative number; $<$, less than; >, greater than; mg, milligrams; kg, kilograms; nr, not reported due to excess concentration; $<$ RL, value less than the reported limit; chemistry results were corrected for dilution and blank corrected prior to calculations]

\begin{tabular}{|c|c|c|c|c|c|c|c|}
\hline & $\begin{array}{c}\mathrm{Ag} \\
\text { (mg leached/kg solid) }\end{array}$ & $\begin{array}{c}\mathrm{Al} \\
\text { (mg leached/kg solid) }\end{array}$ & $\begin{array}{c}\text { As } \\
\text { (mg leached/kg solid) }\end{array}$ & $\begin{array}{c}\mathrm{Ba} \\
\text { (mg leached/kg solid) }\end{array}$ & $\begin{array}{c}\mathrm{Be} \\
\text { (mg leached/kg solid) }\end{array}$ & $\begin{array}{c}\mathrm{Bi} \\
\text { (mg leached/kg solid) }\end{array}$ & $\begin{array}{c}\mathrm{Ca} \\
\text { (mg leached/kg solid) }\end{array}$ \\
\hline Azurite SGF & 2 & 144 & 22 & 601 & 0.2 & $<\mathrm{RL}$ & $<\mathrm{RL}$ \\
\hline dup Azurite SGF & 2 & 146 & 21 & 573 & 0.1 & $<R L$ & $<R L$ \\
\hline Bornite SGF & 15 & 59 & $<R L$ & 4 & $<R L$ & 28 & 1610 \\
\hline Chalcopyrite SGF & 47 & 18 & 2 & 0.6 & $<\mathrm{RL}$ & 84 & $<\mathrm{RL}$ \\
\hline Malachite SGF & $<\mathrm{RL}$ & 71 & $<\mathrm{RL}$ & 1 & 1 & $<R L$ & $<\mathrm{RL}$ \\
\hline Azurite SIF & 5 & 54 & 23 & 572 & 0.06 & $<R L$ & 4 \\
\hline dup Azurite SIF & 5 & 52 & 23 & 561 & 0.07 & $<R L$ & * \\
\hline Bornite SIF & $<R L$ & 38 & 1 & 4 & $<R L$ & 0.2 & 1610 \\
\hline Chalcopyrite SIF & 1 & 6 & 2 & 0.8 & $<\mathrm{RL}$ & 2 & 89 \\
\hline Malachite SIF & 3 & 13 & $<\mathrm{RL}$ & 0.8 & 0.4 & $<R L$ & * \\
\hline Azurite SLF & $<R L$ & 18 & 7 & 12 & $<R L$ & $<R L$ & 117 \\
\hline Bornite SLF & $<R L$ & 8 & $<R L$ & 1 & $<R L$ & $<R L$ & 174 \\
\hline Chalcopyrite SLF & $<R L$ & 6 & 3 & $<R L$ & $<R L$ & 3 & 27 \\
\hline Malachite SLF & $<R L$ & $<\mathrm{RL}$ & $<\mathrm{RL}$ & * & $<R L$ & $<\mathrm{RL}$ & 4 \\
\hline Azurite SPF & & & & & & & \\
\hline Bzurnite SPF & 2 & 6 & $\begin{array}{c}8 \\
0.7\end{array}$ & $\begin{array}{c}63 \\
5\end{array}$ & $\begin{array}{l}0.1 \\
0.1\end{array}$ & $\begin{array}{l}<\mathrm{RL} \\
0.02\end{array}$ & $\begin{array}{c}194 \\
1814\end{array}$ \\
\hline dup Bornite SPF & 0.4 & 7 & 0.6 & 5 & 0.1 & $<R L$ & 1984 \\
\hline Chalcopyrite SPF & 1 & * & 3 & 3 & 0.1 & 2 & 87 \\
\hline Malachite SPF & 0.2 & * & 0.6 & 4 & 0.2 & $<R L$ & * \\
\hline Azurite CCF & 0.2 & 13 & 5 & 37 & $<R L$ & $<R L$ & 164 \\
\hline Bornite CCF & 0.2 & 1 & 0.2 & 3 & $<R L$ & 0.1 & 282 \\
\hline Chalcopyrite CCF & 2 & 0.3 & 3 & * & $<R L$ & 0.2 & 33 \\
\hline Malachite CCF & $<\mathrm{RL}$ & $<\mathrm{RL}$ & 0.3 & 1 & $<R L$ & $<\mathrm{RL}$ & * \\
\hline dup Malachite CCF & $<R L$ & $<R L$ & 0.4 & 1 & $<R L$ & $<R L$ & * \\
\hline
\end{tabular}


Appendix E. Leachate concentrations as milligrams leached per kilograms solid for measured elements by mineral, and as measured in simulated gastric fluid (SGF), simulated intestinal fluid (SIF), simulated lung fluid (SLF), simulated phagolysosomal fluid (SPF), and cell carrier fluid (CCF).—Continued

[*, blank correction resulted in a negative number; <, less than; >, greater than; mg, milligrams; kg, kilograms; nr, not reported due to excess concentration; $<\mathrm{RL}$, value less than the reported limit; chemistry results were corrected for dilution and blank corrected prior to calculations]

\begin{tabular}{|c|c|c|c|c|c|c|c|}
\hline & $\begin{array}{c}\mathrm{Cd} \\
\text { (mg leached } / \mathrm{kg} \text { solid) }\end{array}$ & $\begin{array}{c}\mathrm{Ce} \\
\text { (mg leached/kg solid) }\end{array}$ & $\begin{array}{c}\text { Co } \\
\text { (mg leached/kg solid) }\end{array}$ & $\begin{array}{c}\mathrm{Cr} \\
\text { (mg leached/kg solid) }\end{array}$ & $\begin{array}{c}\text { Cs } \\
\text { (mg leached/kg solid) }\end{array}$ & $\begin{array}{c}\mathrm{Cu} \\
\text { (mg leached } / \mathrm{kg} \text { solid) }\end{array}$ & $\begin{array}{c}\text { Dy } \\
\text { (mg leached/kg solid) }\end{array}$ \\
\hline Azurite SGF & $<R L$ & 0.2 & 3 & * & 0.1 & 221999 & 0.2 \\
\hline dup Azurite SGF & $<R L$ & 0.2 & 2 & * & 0.1 & 217999 & 0.2 \\
\hline Bornite SGF & 1 & 1 & 17 & 0.3 & 0.8 & 8459 & 0.7 \\
\hline Chalcopyrite SGF & 0.9 & 0.08 & 6 & * & 0.1 & 549 & 0.01 \\
\hline Malachite SGF & 0.03 & 2 & 570 & * & $<\mathrm{RL}$ & $>350000$ & 32 \\
\hline Azurite SIF & 0.03 & 0.007 & 2 & * & 0.1 & 208000 & 0.02 \\
\hline dup Azurite SIF & $<R L$ & 0.004 & 2 & * & 0.1 & 211000 & 0.02 \\
\hline Bornite SIF & 1 & 0.2 & 16 & 0.7 & 0.9 & 7970 & 0.1 \\
\hline Chalcopyrite SIF & 0.8 & 0.1 & 5 & 0.2 & 0.1 & 460 & 0.002 \\
\hline Malachite SIF & 0.01 & 0.1 & 563 & * & $<\mathrm{RL}$ & 309000 & 1 \\
\hline Azurite SLF & $<R L$ & $<R L$ & 0.8 & * & 0.3 & 14600 & $<\mathrm{RL}$ \\
\hline Bornite SLF & 2 & $<\mathrm{RL}$ & 10 & * & 0.9 & 4380 & $<\mathrm{RL}$ \\
\hline Chalcopyrite SLF & 0.5 & $<R L$ & 12 & * & 0.2 & 837 & $<R L$ \\
\hline Malachite SLF & $<R L$ & $<\mathrm{RL}$ & 30 & * & $<\mathrm{RL}$ & 13300 & 0.2 \\
\hline & & & & & & & \\
\hline Azurite SPF & 0.01 & * & 6 & * & 0.03 & 36800 & 0.01 \\
\hline Bornite SPF & 4 & * & 29 & * & 1 & 4310 & 0.03 \\
\hline dup Bornite SPF & 4 & * & 32 & 0.1 & 1 & 4580 & 0.03 \\
\hline Chalcopyrite SPF & 2 & * & 17 & * & 0.2 & 441 & 0 \\
\hline Malachite SPF & 0.02 & ${ }^{*}$ & 195 & 0.6 & * & 37000 & 0.9 \\
\hline Azurite CCF & $<\mathrm{RL}$ & 0.01 & 0.8 & * & 0.1 & 6808 & 001 \\
\hline Bornite CCF & 3 & 0.02 & 7 & 0.2 & 0.9 & 1728 & 0.04 \\
\hline Chalcopyrite CCF & 1 & 0 & 12 & * & 0.2 & 363 & $<R L$ \\
\hline Malachite CCF & $<R L$ & 0.04 & 138 & 0.09 & 0.001 & 6008 & 0.1 \\
\hline dup Malachite CCF & * & 0.05 & 140 & 0.2 & * & 6168 & 0.1 \\
\hline
\end{tabular}


Appendix E. Leachate concentrations as milligrams leached per kilograms solid for measured elements by mineral, and as measured in simulated gastric fluid (SGF), simulated intestinal fluid (SIF), simulated lung fluid (SLF), simulated phagolysosomal fluid (SPF), and cell carrier fluid (CCF).—Continued

[*, blank correction resulted in a negative number; <, less than; $>$, greater than; mg, milligrams; kg, kilograms; nr, not reported due to excess concentration; $<$ RL, value less than the reported limit; chemistry results were corrected for dilution and blank corrected prior to calculations]

\begin{tabular}{|c|c|c|c|c|c|c|c|}
\hline & $\begin{array}{c}E r \\
\text { (mg leached/kg solid) }\end{array}$ & $\begin{array}{c}\mathrm{Eu} \\
\text { (mg leached } / \mathrm{kg} \text { solid) }\end{array}$ & $\begin{array}{c}\mathrm{Fe} \\
\text { (mg leached/kg solid) }\end{array}$ & $\begin{array}{c}\mathrm{Ga} \\
\text { (mg leached/kg solid) }\end{array}$ & $\begin{array}{c}\mathrm{Gd} \\
\text { (mg leached/kg solid) }\end{array}$ & $\begin{array}{c}\mathrm{Ge} \\
\text { (mg leached/kg solid) }\end{array}$ & $\begin{array}{c}\text { Ho } \\
\text { (mg leached/kg solid) }\end{array}$ \\
\hline Azurite SGF & 0.2 & 0.2 & $<\mathrm{RL}$ & 0.1 & 0.1 & $<R L$ & 0.1 \\
\hline dup Azurite SGF & 0.2 & 0.2 & $<\mathrm{RL}$ & 0.1 & 0.1 & $<\mathrm{RL}$ & 0.1 \\
\hline Bornite SGF & 0.2 & 0.4 & 1580 & 0.1 & 2 & $<R L$ & 0.1 \\
\hline Chalcopyrite SGF & 0.006 & $<\mathrm{RL}$ & 642 & $<\mathrm{RL}$ & 0.02 & $<R L$ & $<\mathrm{RL}$ \\
\hline Malachite SGF & 25 & 7 & $<R L$ & 0.6 & 22 & $<R L$ & 7 \\
\hline Azurite SIF & 0.02 & 0.2 & $<R L$ & $<R L$ & 0.01 & $<R L$ & 0.01 \\
\hline dup Azurite SIF & 0.04 & 0.1 & $<R L$ & $<R L$ & 0.02 & $<\mathrm{RL}$ & 0.01 \\
\hline Bornite SIF & 0.04 & 0.1 & 325 & 0.1 & 0.3 & $<\mathrm{RL}$ & 0.02 \\
\hline Chalcopyrite SIF & 0.001 & $<\mathrm{RL}$ & 222 & $<\mathrm{RL}$ & 0.001 & $<\mathrm{RL}$ & $<R L$ \\
\hline Malachite SIF & 1 & 0.2 & $<\mathrm{RL}$ & 0.3 & 0.7 & $<\mathrm{RL}$ & 0.3 \\
\hline Azurite SLF & 0.005 & $<R L$ & $<R L$ & 0.009 & $<R L$ & $<R L$ & $<R L$ \\
\hline Bornite SLF & $<\mathrm{RL}$ & $<R L$ & $<\mathrm{RL}$ & 0.008 & $<\mathrm{RL}$ & $<R L$ & $<R L$ \\
\hline Chalcopyrite SLF & $<R L$ & $<R L$ & 216 & 0.002 & $<R L$ & $<R L$ & $<R L$ \\
\hline Malachite SLF & 0.2 & 0.02 & $<\mathrm{RL}$ & 0 & 0.1 & $<\mathrm{RL}$ & 0.06 \\
\hline & & & & & & & \\
\hline Azurite SPF & 0.01 & 0.00 & $<R L$ & * & 0.00 & $<R L$ & 0.00 \\
\hline Bornite SPF & 0.03 & 0.01 & 27 & * & 0.01 & $<\mathrm{RL}$ & 0.01 \\
\hline dup Bornite SPF & 0.02 & 0.01 & 29 & * & 0.01 & 0.01 & 0.01 \\
\hline Chalcopyrite SPF & 0.00 & $<\mathrm{RL}$ & 25 & * & $<\mathrm{RL}$ & 0.01 & 0.00 \\
\hline Malachite SPF & 0.6 & 0.4 & $<R L$ & 0.01 & 0.14 & 0.01 & 0.20 \\
\hline Azurite CCF & 0.01 & 0.002 & 4 & $<R L$ & $<R L$ & 0.02 & 0.002 \\
\hline Bornite CCF & 0.03 & 0.01 & 4 & 0.005 & 0.01 & 0.01 & 0.02 \\
\hline Chalcopyrite CCF & $<\mathrm{RL}$ & $<\mathrm{RL}$ & 7 & $<R L$ & $<R L$ & 0.02 & $<\mathrm{RL}$ \\
\hline Malachite CCF & 0.06 & 0.03 & $<\mathrm{RL}$ & $<\mathrm{RL}$ & 0.01 & 0.02 & 0.02 \\
\hline dup Malachite CCF & 0.04 & 0.03 & 2 & 0.006 & 0.01 & 0.01 & 0.02 \\
\hline
\end{tabular}


Appendix E. Leachate concentrations as milligrams leached per kilograms solid for measured elements by mineral, and as measured in simulated gastric fluid (SGF), simulated intestinal fluid (SIF), simulated lung fluid (SLF), simulated phagolysosomal fluid (SPF), and cell carrier fluid (CCF).—Continued

[*, blank correction resulted in a negative number; <, less than; >, greater than; mg, milligrams; kg, kilograms; nr, not reported due to excess concentration; $<$ RL, value less than the reported limit; chemistry results were corrected for dilution and blank corrected prior to calculations]

\begin{tabular}{|c|c|c|c|c|c|c|c|}
\hline & $\begin{array}{c}\mathrm{K} \\
\text { (mg leached/kg solid) }\end{array}$ & $\begin{array}{c}\mathrm{La} \\
\text { (mg leached/kg solid) }\end{array}$ & $\begin{array}{c}\mathrm{Li} \\
\text { (mg leached/kg solid) }\end{array}$ & $\begin{array}{c}\mathrm{Lu} \\
\text { (mg leached/kg solid) }\end{array}$ & $\begin{array}{c}\mathrm{Mg} \\
\text { (mg leached/kg solid) }\end{array}$ & $\begin{array}{c}\mathrm{Mn} \\
\text { (mg leached/kg solid) }\end{array}$ & $\begin{array}{c}\text { Mo } \\
\text { (mg leached/kg solid) }\end{array}$ \\
\hline Azurite SGF & 52 & 0.08 & $<R L$ & $<R L$ & 37 & 3 & $<R L$ \\
\hline dup Azurite SGF & 49 & 0.08 & $<\mathrm{RL}$ & $<\mathrm{RL}$ & 36 & 2 & $<\mathrm{RL}$ \\
\hline Bornite SGF & 49 & 0.4 & 0.4 & $<R L$ & 48 & 28 & $<R L$ \\
\hline Chalcopyrite SGF & 30 & 0.04 & 0.7 & $<\mathrm{RL}$ & 11 & 8 & $<R L$ \\
\hline Malachite SGF & $<\mathrm{RL}$ & 4 & 0.5 & 4 & 17 & 142 & $<R L$ \\
\hline Azurite SIF & * & 0.01 & $<R L$ & $<R L$ & 29 & 5 & $<R L$ \\
\hline dup Azurite SIF & * & 0.01 & $<R L$ & $<R L$ & 25 & 5 & $<R L$ \\
\hline Bornite SIF & * & 0.08 & $<\mathrm{RL}$ & $<\mathrm{RL}$ & 60 & 29 & $<R L$ \\
\hline Chalcopyrite SIF & * & 0.01 & $<\mathrm{RL}$ & $<R L$ & 3 & 11 & $<R L$ \\
\hline Malachite SIF & * & 0.2 & $<R L$ & 0.2 & 2 & 180 & $<R L$ \\
\hline Azurite SLF & 115 & $<R L$ & * & $<R L$ & 27 & 1 & $<R L$ \\
\hline Bornite SLF & 82 & $<R L$ & * & $<R L$ & 10 & 7 & $<R L$ \\
\hline Chalcopyrite SLF & 50 & $<\mathrm{RL}$ & 0.3 & $<\mathrm{RL}$ & $<\mathrm{RL}$ & 4 & $<R L$ \\
\hline Malachite SLF & 94 & $<R L$ & * & $<\mathrm{RL}$ & $<R L$ & 4 & $<R L$ \\
\hline & & & & & & & \\
\hline Azurite SPF & * & 0.01 & & $<R L$ & 54 & 5 & $<R L$ \\
\hline Bornite SPF & * & 0.03 & 0.7 & $<R L$ & 37 & 34 & $<\mathrm{RL}$ \\
\hline dup Bornite SPF & * & 0.03 & 0.5 & $<\mathrm{RL}$ & 40 & 36 & $<R L$ \\
\hline Chalcopyrite SPF & * & 0.008 & 1 & $<\mathrm{RL}$ & 26 & 17 & $<R L$ \\
\hline Malachite SPF & * & 0.4 & 0.3 & 0.08 & 10 & 69 & $<R L$ \\
\hline Azurite CCF & 90 & 0.004 & $<\mathrm{RL}$ & $<R L$ & 10 & 2 & $<R L$ \\
\hline Bornite CCF & 80 & 0.006 & $<R L$ & $<R L$ & * & 8 & $<R L$ \\
\hline Chalcopyrite CCF & * & * & $<\mathrm{RL}$ & $<\mathrm{RL}$ & * & 5 & $<R L$ \\
\hline Malachite CCF & * & 0.04 & $<R L$ & $<R L$ & * & 74 & 0.6 \\
\hline dup Malachite CCF & * & 0.03 & $<R L$ & 0.01 & * & 78 & 0.7 \\
\hline
\end{tabular}


Appendix E. Leachate concentrations as milligrams leached per kilograms solid for measured elements by mineral, and as measured in simulated gastric fluid (SGF), simulated intestinal fluid (SIF), simulated lung fluid (SLF), simulated phagolysosomal fluid (SPF), and cell carrier fluid (CCF).—Continued

${ }^{*}$, blank correction resulted in a negative number; <, less than; $>$, greater than; mg, milligrams; kg, kilograms; nr, not reported due to excess concentration; $<$ RL, value less than the reported limit; chemistry results were corrected for dilution and blank corrected prior to calculations]

\begin{tabular}{|c|c|c|c|c|c|c|c|}
\hline & $\begin{array}{c}\mathrm{Na} \\
\text { (mg leached/kg solid) }\end{array}$ & $\begin{array}{c}\mathrm{Nb} \\
\text { (mg leached/kg solid) }\end{array}$ & $\begin{array}{c}\mathrm{Nd} \\
\text { (mg leached/kg solid) }\end{array}$ & $\begin{array}{c}\mathrm{Ni} \\
\text { (mg leached/kg solid) }\end{array}$ & $\begin{array}{c}\mathrm{P} \\
\text { (mg leached/kg solid) }\end{array}$ & $\begin{array}{c}\mathrm{Pb} \\
\text { (mg leached/kg solid) }\end{array}$ & $\begin{array}{c}\mathrm{Pr} \\
\text { (mg leached } / \mathrm{kg} \text { solid) }\end{array}$ \\
\hline Azurite SGF & 360 & $<\mathrm{RL}$ & 0.2 & 0.7 & 10 & 3 & 0.04 \\
\hline dup Azurite SGF & 374 & $<R L$ & 0.2 & 0.6 & 20 & 4 & 0.03 \\
\hline Bornite SGF & 48 & $<R L$ & 3 & 6 & 150 & 189 & 0.3 \\
\hline Chalcopyrite SGF & 50 & $<R L$ & 0.1 & 1 & 100 & 74 & 0.01 \\
\hline Malachite SGF & 21 & $<R L$ & 53 & 2270 & $<R L$ & 179 & 8 \\
\hline Azurite SIF & $\mathrm{nr}$ & $<\mathrm{RL}$ & 0.03 & 0.7 & * & 03 & $<R L$ \\
\hline dup Azurite SIF & $\mathrm{nr}$ & $<R L$ & 0.03 & 0.7 & * & 0.3 & $<R L$ \\
\hline Bornite SIF & $\mathrm{nr}$ & $<R L$ & 0.5 & 6 & * & 66 & 0.1 \\
\hline Chalcopyrite SIF & $\mathrm{nr}$ & $<R L$ & 0.02 & 1 & * & 31 & $<R L$ \\
\hline \multirow[t]{2}{*}{ Malachite SIF } & $\mathrm{nr}$ & $<\mathrm{RL}$ & 2 & 2190 & * & 10 & 0.3 \\
\hline & $\mathrm{nr}$ & & & & & & \\
\hline Azurite SLF & $\mathrm{nr}$ & $<R L$ & $<R L$ & $<R L$ & * & $<R L$ & $<R L$ \\
\hline Bornite SLF & $\mathrm{nr}$ & $<R L$ & $<R L$ & 6 & 20 & 94 & $<R L$ \\
\hline Chalcopyrite SLF & $\mathrm{nr}$ & $<R L$ & $<R L$ & 2 & * & 8 & $<R L$ \\
\hline Malachite SLF & $\mathrm{nr}$ & $<\mathrm{RL}$ & 0.06 & 76 & * & $<\mathrm{RL}$ & $<\mathrm{RL}$ \\
\hline & & & & & & & \\
\hline Azurite SPF & $\mathrm{nr}$ & $<R L$ & 0.006 & 0.7 & * & 3 & 0.005 \\
\hline Bornite SPF & $\mathrm{nr}$ & $<\mathrm{RL}$ & 0.10 & 12 & * & 544 & 0.02 \\
\hline dup Bornite SPF & $\mathrm{nr}$ & $<\mathrm{RL}$ & 0.1 & 13 & * & 567 & 0.02 \\
\hline Chalcopyrite SPF & $\mathrm{nr}$ & $<\mathrm{RL}$ & 0.01 & 3 & * & 84 & 0.002 \\
\hline Malachite SPF & $\mathrm{nr}$ & $<\mathrm{RL}$ & 3 & 258 & * & 10 & 0.51 \\
\hline Azurite CCF & * & 0.04 & 0.008 & 0.3 & * & 0.19 & $<R L$ \\
\hline Bornite CCF & * & $<\mathrm{RL}$ & 0.01 & 4 & * & 53 & 0.002 \\
\hline Chalcopyrite CCF & * & 0.048 & $<\mathrm{RL}$ & 2 & * & 2 & $<R L$ \\
\hline Malachite CCF & * & $<R L$ & 0.2 & 62 & * & 0.68 & 0.04 \\
\hline dup Malachite CCF & * & $<\mathrm{RL}$ & 0.2 & 64 & * & 0.46 & 0.04 \\
\hline
\end{tabular}


Appendix E. Leachate concentrations as milligrams leached per kilograms solid for measured elements by mineral, and as measured in simulated gastric fluid (SGF),

simulated intestinal fluid (SIF), simulated lung fluid (SLF), simulated phagolysosomal fluid (SPF), and cell carrier fluid (CCF).—Continued

[*, blank correction resulted in a negative number; <, less than; >, greater than; mg, milligrams; kg, kilograms; nr, not reported due to excess concentration; <RL, value less than the reported limit; chemistry results were corrected for dilution and blank corrected prior to calculations]

\begin{tabular}{|c|c|c|c|c|c|c|c|}
\hline & $\begin{array}{c}\mathrm{Rb} \\
\text { (mg leached/kg solid) }\end{array}$ & $\begin{array}{c}\mathrm{Sb} \\
\text { (mg leached/kg solid) }\end{array}$ & $\begin{array}{c}\mathrm{Sc} \\
\text { (mg leached/kg solid) }\end{array}$ & $\begin{array}{c}\mathrm{Se} \\
\text { (mg leached/kg solid) }\end{array}$ & $\begin{array}{c}\mathrm{SiO} 2 \\
\text { (mg leached/kg solid) }\end{array}$ & $\begin{array}{c}\mathrm{Sm} \\
\text { (mg leached/kg solid) }\end{array}$ & $\begin{array}{c}\mathrm{SO} 4 \\
\text { (mg leached/kg solid) }\end{array}$ \\
\hline Azurite SGF & 0.2 & $<R L$ & 0.7 & $<R L$ & 0 & 0.1 & $<R L$ \\
\hline dup Azurite SGF & 0.2 & $<R L$ & 0.9 & $<R L$ & 70 & 0.1 & $<R L$ \\
\hline Bornite SGF & 0.5 & 0.4 & 0.7 & $<R L$ & 660 & 2 & $<R L$ \\
\hline Chalcopyrite SGF & 0.1 & 0.5 & $<R L$ & $<R L$ & 350 & 0.02 & $<R L$ \\
\hline Malachite SGF & 0.02 & $<R L$ & 63 & $<R L$ & -90 & 21 & $<R L$ \\
\hline & & & & & & & \\
\hline Azurite SIF & -1 & 0.4 & $<\mathrm{RL}$ & $<\mathrm{RL}$ & * & 0.02 & * \\
\hline dup Azurite SIF & -1 & $<\mathrm{RL}$ & $<R L$ & $<\mathrm{RL}$ & * & 0.02 & * \\
\hline Bornite SIF & 0.5 & 0.9 & $<R L$ & $<R L$ & 150 & 0.3 & * \\
\hline Chalcopyrite SIF & -0.1 & 0.7 & $<R L$ & $<R L$ & * & $<R L$ & * \\
\hline Malachite SIF & -2 & $<R L$ & $<R L$ & $<R L$ & * & 0.7 & * \\
\hline & & & & & & & \\
\hline Azurite SLF & 0.3 & $<R L$ & $<R L$ & $<R L$ & 260 & $<R L$ & 400 \\
\hline Bornite SLF & 0.6 & $<\mathrm{RL}$ & $<\mathrm{RL}$ & $<\mathrm{RL}$ & 110 & $<\mathrm{RL}$ & 1700 \\
\hline Chalcopyrite SLF & 0.2 & $<\mathrm{RL}$ & $<R L$ & -0.1 & 70 & $<\mathrm{RL}$ & 2800 \\
\hline Malachite SLF & 0.03 & $<R L$ & $<R L$ & $<\mathrm{RL}$ & * & $<\mathrm{RL}$ & 600 \\
\hline Azurite SPF & 0.03 & 0.05 & 0.06 & 0.05 & 30 & 0.005 & * \\
\hline Bornite SPF & 0.5 & 0.5 & 0.1 & 0.4 & * & 0.03 & * \\
\hline dup Bornite SPF & 0.6 & 0.4 & 0.1 & $<R L$ & 30 & 0.03 & * \\
\hline Chalcopyrite SPF & 0.08 & 0.2 & 0.1 & 0.02 & * & 0.02 & * \\
\hline Malachite SPF & -0.2 & 0.06 & 0.1 & $<R L$ & * & 1 & * \\
\hline Azurite CCF & 0.2 & 0.07 & 0.07 & * & 220 & $<R L$ & 1900 \\
\hline Bornite CCF & 0.7 & 0.2 & 0.08 & * & 120 & 0.01 & 3200 \\
\hline Chalcopyrite CCF & 0.3 & 0.2 & 0.2 & * & 20 & 0.005 & * \\
\hline Malachite CCF & 0.08 & 0.06 & 0.2 & * & 60 & 0.1 & * \\
\hline dup Malachite CCF & 0.1 & 0.09 & 0.3 & * & 50 & 0.07 & * \\
\hline
\end{tabular}


Appendix E. Leachate concentrations as milligrams leached per kilograms solid for measured elements by mineral, and as measured in simulated gastric fluid (SGF), simulated intestinal fluid (SIF), simulated lung fluid (SLF), simulated phagolysosomal fluid (SPF), and cell carrier fluid (CCF).—Continued

[*, blank correction resulted in a negative number; <, less than; >, greater than; mg, milligrams; kg, kilograms; nr, not reported due to excess concentration; <RL, value less than the reported limit; chemistry results were corrected for dilution and blank corrected prior to calculations]

\begin{tabular}{|c|c|c|c|c|c|c|c|}
\hline & $\begin{array}{c}\mathrm{Sr} \\
\text { (mg leached/kg solid) }\end{array}$ & $\begin{array}{c}\mathrm{Ta} \\
\text { (mg leached/kg solid) }\end{array}$ & $\begin{array}{c}\mathrm{Tb} \\
\text { (mg leached/kg solid) }\end{array}$ & $\begin{array}{c}\text { Th } \\
\text { (mg leached/kg solid) }\end{array}$ & $\begin{array}{c}\mathrm{Ti} \\
\text { (mg leached/kg solid) }\end{array}$ & $\begin{array}{c}\mathrm{Tl} \\
\text { (mg leached/kg solid) }\end{array}$ & $\begin{array}{c}\mathrm{Tm} \\
\text { (mg leached } / \mathrm{kg} \text { solid) }\end{array}$ \\
\hline Azurite SGF & 1 & $<R L$ & 0.03 & 2 & $<\mathrm{RL}$ & $<R L$ & 0.05 \\
\hline dup Azurite SGF & 1 & $<R L$ & 0.02 & 2 & $<\mathrm{RL}$ & $<R L$ & 0.04 \\
\hline Bornite SGF & 3 & $<R L$ & 0.2 & 0.8 & 0.1 & 0.3 & 0.03 \\
\hline Chalcopyrite SGF & 0.5 & $<\mathrm{RL}$ & $<R L$ & 0.3 & 0.03 & $<R L$ & $<\mathrm{RL}$ \\
\hline Malachite SGF & $<R L$ & $<R L$ & 4 & 0.5 & $<\mathrm{RL}$ & $<R L$ & 4 \\
\hline Azurite SIF & 1 & * & $<R L$ & $<R L$ & $<R L$ & $<R L$ & 0.002 \\
\hline dup Azurite SIF & 1 & * & $<R L$ & $<R L$ & $<R L$ & $<R L$ & 0.002 \\
\hline Bornite SIF & 3 & * & 0.03 & $<\mathrm{RL}$ & $<\mathrm{RL}$ & 0.4 & 0.003 \\
\hline Chalcopyrite SIF & 0.4 & * & $<R L$ & $<\mathrm{RL}$ & $<R L$ & $<\mathrm{RL}$ & $<\mathrm{RL}$ \\
\hline Malachite SIF & 0.1 & * & 0.2 & $<\mathrm{RL}$ & $<\mathrm{RL}$ & $<\mathrm{RL}$ & 0.2 \\
\hline & & & & & & & \\
\hline Azurite SLF & 1.2 & $<R L$ & $<R L$ & $<R L$ & $<R L$ & $<R L$ & $<R L$ \\
\hline Bornite SLF & 0.9 & $<\mathrm{RL}$ & $<\mathrm{RL}$ & $<\mathrm{RL}$ & $<R L$ & $<\mathrm{RL}$ & $<\mathrm{RL}$ \\
\hline Chalcopyrite SLF & 0.2 & $<\mathrm{RL}$ & $<\mathrm{RL}$ & $<\mathrm{RL}$ & $<R L$ & $<\mathrm{RL}$ & $<\mathrm{RL}$ \\
\hline Malachite SLF & 0.09 & $<R L$ & $<R L$ & $<\mathrm{RL}$ & $<R L$ & $<\mathrm{RL}$ & $<\mathrm{RL}$ \\
\hline & & & & & & & \\
\hline Azurite SPF & 2 & $<R L$ & 0.006 & $<R L$ & 0.2 & $<R L$ & 0.001 \\
\hline Bornite SPF & 3 & $<\mathrm{RL}$ & 0.03 & $<\mathrm{RL}$ & 0.2 & 0.2 & 0.002 \\
\hline dup Bornite SPF & 4 & $<\mathrm{RL}$ & 0.05 & $<\mathrm{RL}$ & 0.4 & 0.2 & 0.006 \\
\hline Chalcopyrite SPF & 0.8 & $<\mathrm{RL}$ & $<R L$ & $<\mathrm{RL}$ & 0.3 & 0.06 & $<\mathrm{RL}$ \\
\hline Malachite SPF & 0.4 & $<\mathrm{RL}$ & 0.9 & $<\mathrm{RL}$ & 0.3 & 0.01 & 0.08 \\
\hline Azurite CCF & 2 & 0.003 & 0.001 & $<R L$ & 0.3 & $<R L$ & 0.001 \\
\hline Bornite CCF & 2 & $<R L$ & 0.06 & $<R L$ & 0.3 & 0.1 & 0.004 \\
\hline Chalcopyrite CCF & 0.5 & 0.008 & $<R L$ & 0.024 & 0.3 & 0.02 & $<\mathrm{RL}$ \\
\hline Malachite CCF & 0.3 & $<\mathrm{RL}$ & 0.06 & $<\mathrm{RL}$ & * & 0.01 & 0.01 \\
\hline dup Malachite CCF & 0.3 & $<\mathrm{RL}$ & 0.08 & $<\mathrm{RL}$ & * & $<\mathrm{RL}$ & 0.01 \\
\hline
\end{tabular}


Appendix E. Leachate concentrations as milligrams leached per kilograms solid for measured elements by mineral, and as measured in simulated gastric fluid (SGF), simulated intestinal fluid (SIF), simulated lung fluid (SLF), simulated phagolysosomal fluid (SPF), and cell carrier fluid (CCF).—Continued

[*, blank correction resulted in a negative number; <, less than; >, greater than; mg, milligrams; kg, kilograms; nr, not reported due to excess concentration; $<\mathrm{RL}$, value less than the reported limit; chemistry results were corrected for dilution and blank corrected prior to calculations]

\begin{tabular}{|c|c|c|c|c|c|c|c|}
\hline & $\begin{array}{c}U \\
\text { (mg leached/kg solid) }\end{array}$ & $\begin{array}{c}\mathrm{V} \\
\text { (mg leached/kg solid) }\end{array}$ & $\begin{array}{c}\text { W } \\
\text { (mg leached/kg solid) }\end{array}$ & $\begin{array}{c}\mathrm{Y} \\
\text { (mg leached/kg solid) }\end{array}$ & $\begin{array}{c}\mathrm{Yb} \\
\text { (mg leached/kg solid) }\end{array}$ & $\begin{array}{c}\mathrm{Zn} \\
\text { (mg leached/kg solid) }\end{array}$ & $\begin{array}{c}\mathrm{Zr} \\
\text { (mg leached/kg solid) }\end{array}$ \\
\hline Azurite SGF & 0.4 & 0.7 & $<R L$ & 1 & 0.4 & * & $<R L$ \\
\hline dup Azurite SGF & 0.3 & 0.6 & $<R L$ & 1 & 0.4 & * & $<R L$ \\
\hline Bornite SGF & 0.8 & 2 & $<R L$ & 3 & 0.2 & 110 & $<R L$ \\
\hline Chalcopyrite SGF & $<\mathrm{RL}$ & 0.07 & $<\mathrm{RL}$ & 0.05 & 0.006 & 24 & $<R L$ \\
\hline Malachite SGF & 265 & * & $<\mathrm{RL}$ & 32 & 31 & 4 & $<\mathrm{RL}$ \\
\hline Azurite SIF & $<R L$ & 0.2 & $<R L$ & 0.2 & 0.07 & * & $<\mathrm{RL}$ \\
\hline dup Azurite SIF & $<\mathrm{RL}$ & 0.06 & $<\mathrm{RL}$ & 0.2 & 0.07 & * & $<R L$ \\
\hline Bornite SIF & $<\mathrm{RL}$ & 2 & $<\mathrm{RL}$ & 0.6 & 0.05 & 82 & $<\mathrm{RL}$ \\
\hline Chalcopyrite SIF & $<\mathrm{RL}$ & * & $<\mathrm{RL}$ & 0.1 & 0.03 & 18 & $<\mathrm{RL}$ \\
\hline Malachite SIF & 5 & * & $<R L$ & 2 & 2 & * & $<\mathrm{RL}$ \\
\hline Azurite SLF & 0.3 & 1 & $<R L$ & 0.04 & * & 5 & $<R L$ \\
\hline Bornite SLF & 0.7 & 0.7 & $<R L$ & 0.01 & $<R L$ & 162 & $<\mathrm{RL}$ \\
\hline Chalcopyrite SLF & 0.2 & $<R L$ & $<R L$ & $<R L$ & $<R L$ & 20 & $<R L$ \\
\hline Malachite SLF & 49 & $<R L$ & $<R L$ & 0.4 & 0.4 & $<R L$ & $<R L$ \\
\hline Azurite SPF & 0.2 & 0.7 & $<R L$ & 0.2 & 0.004 & 2 & $<R L$ \\
\hline Bornite SPF & 0.7 & 0.9 & $<R L$ & 0.2 & 0.02 & 348 & $<R L$ \\
\hline dup Bornite SPF & 0.7 & 1.0 & $<\mathrm{RL}$ & 0.2 & 0.02 & 359 & $<\mathrm{RL}$ \\
\hline Chalcopyrite SPF & 0.09 & 0.2 & $<R L$ & 0.01 & * & 173 & $<\mathrm{RL}$ \\
\hline Malachite SPF & 47 & 0.07 & $<R L$ & 1 & 0.5 & 1 & $<R L$ \\
\hline Azurite CCF & 0.1 & 0.6 & * & 0.05 & 0 & * & 0.2 \\
\hline Bornite CCF & 0.5 & 0.3 & * & 0.3 & 0.03 & 192 & 0.03 \\
\hline Chalcopyrite CCF & 0.09 & -0.02 & 0.1 & 0.002 & * & 39 & 0.05 \\
\hline Malachite CCF & 19 & 0.04 & * & 0.1 & 0.06 & * & $<\mathrm{RL}$ \\
\hline dup Malachite CCF & 18 & 0.06 & * & 0.1 & 0.07 & * & $<R L$ \\
\hline
\end{tabular}


